\title{
On small farms and the design of contracts in agricultural markets - Experimental evidence from Vietnam
}

\author{
Dissertation \\ zur Erlangung des Doktorgrades \\ im Promotionsstudiengang Internationales PhD. Programm für Agrarwissenschaften \\ (IPAG), \\ der Fakultät für Agrarwissenschaften, \\ der Georg-August-Universität Göttingen
}

vorgelegt von

Christoph Sänger

geboren in Lübeck

Göttingen, März 2012 
D7

1. Name of supervisor: Prof. Dr. Matin Qaim

2. Name of co-supervisor: JProf. Dr. Marcela Ibáñez,

Date of dissertation: 31.05.2012 


\section{Summary}

Over the past two decades the agrifood industry in developing countries has undergone rapid modernization. Economic growth, rising incomes, urbanization and the spread of western lifestyles have led to changes in consumption patterns in Asia and parts of Africa. As a result, the domestic demand for high-value agricultural products like fruit, vegetables, milk and meat has increased. Meeting consumers' high expectations regarding product quality attributes presents an immense challenge to processors, wholesalers and retailers. As year-round supply of consistently highquality produce is becoming crucial, the degree of control required in the procurement process is increasing and traditional supply chains based on anonymous spot-market transactions are reaching their limits. Hence, vertical integration is encouraged, often through contract farming arrangements between buying firms and selling farmers encompassing a broad array of oral or written agreements that utilize various incentive instruments to ensure a steady supply of high-quality agricultural produce.

The analysis of opportunities and challenges for smallholder participation in emerging high-value markets has drawn the attention of researchers. While a large body of literature has emerged, results seem to be mixed. If included in modern supply chains, smallholders can greatly benefit from a combination of access to credit, inputs, and improved technology, leading to higher productivity and higher and more stable incomes. However, there is also evidence that small-scale farmers 
struggle to comply with contract terms and fulfill the strict quality requirements. Further, the purchasing firms often prefer to source raw material from large farmers due to lower per-unit transaction costs. These factors may lead to a further marginalization of smallholders.

In contract farming arrangements, buyers often use output quality as proxy for effort exerted by farmers during the production process. Linking compensation to output quality helps to economize on monitoring costs and can incentivize production of high-quality output. However, there is little information on how to tailor contracts to fit smallholder environments while taking into account specific characteristics of small-scale farmers, such as risk aversion. Further, if farmers' compensation is closely linked to output quality, transparency of the system for quality measurement becomes increasingly important. If product quality attributes are observable to the buyer but not to the selling farmer, opportunistic buyers could report lower than actual output quality, negatively affecting farmers' compensation. If farmers assume buyer's potential opportunistic behavior, they may underinvest, i.e. use suboptimal amounts of input, limiting farm productivity.

Therefore, writing effective contracts by adapting incentive instruments to smallholder environments could free yet untapped productivity reserves. In addition, increasing transparency in the procurement process could lift informational constraints that limit farm productivity, increasing the attractiveness of smallholders as contract partners and encouraging their participation in high-value markets.

We use the example of the Vietnamese dairy sector, which is an interesting case of an emerging high-value market. In close cooperation with a large milk processing company, we conducted a framed field experiment with dairy farmers to 
test various financial incentives such as bonuses and penalties in a controlled environment. Furthermore, using the same population of milk producers, we ran a field experiment lasting twelve months in which contracts were enforced for randomly selected dairy farmers by providing them with the opportunity to independently verify milk testing results reported by the dairy company. To analyze the experiments, in three rounds of extensive surveys we collected comprehensive household information for all participating milk producers. This information is complemented with detailed production data for each dairy farmer, provided by the dairy company.

The results of the framed field experiment shed light on the effectiveness of the contract structure that is currently used by the dairy processor. We find that financial penalties drive farmers into higher input use, resulting in better quality output for the processing company. A conditional bonus payment generates an even higher quality output. We also find that input choice levels are dependent on farmers' socioeconomic characteristics, such as wealth levels, while risk preferences seem to be less important for input choice.

The field experiment yields interesting insights on the impact of more transparency in the supply chain. Providing farmers with the opportunity to verify testing results provided by the dairy company helps to overcome the existing information asymmetry on output quality. We observe a 10 percent higher use of inputs when contracts are enforced, resulting in significantly higher dairy output and welfare levels increase for specific subgroups of farmers. Further, in the underlying case we find that the buying company had not behaved opportunistically, underreporting output quality to accrue quasi-rents despite the existing information 
asymmetry. Hence, third-party enforcement helped the company to credibly signal its fairness to farmers, leading to a Pareto improvement in the supply chain: While producers benefit directly from higher farm productivity, firms that do not underreport quality are better off due to lower per-unit transaction costs in output procurement.

We show that financial incentives which are linked to quality attributes can be effective in assuring high-quality production. However, the full potential of these conditional incentives unfolds only if the system of quality assessment is transparent. The trend in the results can be generalized over a variety of markets in which quality attributes are important, in Vietnam and elsewhere. 


\section{Zusammenfassung}

Seit rund zwei Jahrzehnten unterliegt die Land- und Ernährungswirtschaft in weniger entwickelten Ländern einem stetigen Modernisierungsprozess und Wandel. Wirtschaftswachstum, steigende Einkommen, Verstädterung sowie die zunehmende Verbreitung eines westlich geprägten Lebensstils gehen mit signifikanten Veränderungen der Ernährungsgewohnheiten von Verbrauchern in Asien und seit kurzem auch in vielen Ländern Afrikas einher. In der Folge ist die lokale Nachfrage nach hochwertigen Agrarprodukten, wie Obst und Gemüse, aber auch Fleisch und Milch sprunghaft angestiegen. Akteure in der Wertschöpfungskette, wie z.B. verarbeitende Unternehmen sowie Groß- und Einzelhandel stellen die wachsenden Ansprüche der Konsumenten bezüglich hochwertiger und frischer, ganzjährig verfügbarer Agrarprodukte vor neue Herausforderungen. Dabei zeigt sich, dass sich mit traditionellen Lieferketten, die auf lokalen Märkten beruhen, die Sicherstellung der Versorgung mit hochwertigen landwirtschaftlichen Rohstoffen oft nicht mehr zufriedenstellend lösen lässt, da verstärkte Koordination zwischen den Marktteilnehmern geboten ist. Eine mittlerweile weit verbreitete Lösung für das Koordinationsproblem innerhalb der Lieferkette sind Vertragslandwirtschaftssysteme. Die Verträge, die das Verhältnis zwischen Käufer und Landwirt regeln, können sowohl mündlicher, als auch schriftlicher Natur sein und umfassen meist eine großen Bandbreite von Anreizmechanismen, die auch der Sicherung der Qualität bei der Erfassung der Rohstoffe dienen. 
Nach derzeitigem Stand der Forschung können Kleinbauern, so sie denn in Märkten für hochwertige Agrarprodukte eingebunden werden, in großem Maße profitieren, z.B. durch verbesserten Zugang zu Krediten, Betriebsmitteln, modernen Technologien sowie Produktivitätssteigerungen und höherem, weniger stark schwankenden Einkommen. Allerdings gibt es auch Hinweise darauf, dass Kleinbauern Schwierigkeiten haben, die vertraglichen Auflagen hinsichtlich der erwarteten Qualität und Menge sowie des Lieferzeitpunkts zu erfüllen. Außerdem erfassen verarbeitende Unternehmen und Großhändler die Rohstoffe auf Grund niedrigerer Transaktionskosten bevorzugt von größeren landwirtschaftlichen Betrieben. In der Summe führt dies dazu, dass Kleinbauern häufig nicht in wachsende Märkte für hochwertige Agrarprodukte eingebunden werden, was zu einer weiteren Marginalisierung beitragen kann.

In vertragslandwirtschaftlichen Kontrakten stützen sich die Käufer oft auf Produktqualität als Hilfsvariable, um den Aufwand des Produzenten nachträglich, mit im Vergleich zur direkten Überwachung des Betriebsmitteleinsatzes niedrigeren Kosten zu bewerten. Wenn die Bezahlung an die Produktqualität gebunden ist, werden Anreize zur Lieferung hoher Qualitäten gesetzt. Allerdings liegen gerade für Vertragssysteme mit Kleinbauern kaum Erkenntnisse vor, wie Verträge und deren Anreizinstrumente gestaltetet sein müssen, um den besonderen Eigenschaften vieler Kleinbauern, wie z.B. der hohen Risikoaversion gerecht zu werden. Außerdem wird die Nachvollziehbarkeit und Transparenz des vom Käufer genutzten Systems zur Qualitätsmessung zunehmend bedeutsam, wenn die Bezahlung der Landwirte an bestimmte Qualitätsparameter gebunden ist. Wenn Qualitätsmerkmale zwar für den Käufer, nicht aber den verkaufenden Landwirt erkennbar sind, dann besteht die 
Möglichkeit dass Käufer sich opportunistisch verhalten und eine geringere als die tatsächliche Qualität abrechnen, was zu finanziellen Einbußen bei den Landwirten führt. Wenn die landwirtschaftlichen Produzenten ein mögliches opportunistisches Verhalten seitens der Käufer in ihr Kalkül aufnehmen, könnte das zu vorsichtigeren Investitionsentscheidungen und geringerem Betriebsmitteleinsatz führen, mit der Folge, dass die Produktivität sinkt.

Deshalb ist es wichtig Verträge so zu gestalten, dass durch Wahl von für Kleinbauernverhältnisse optimierten finanziellen Anreizinstrumenten einerseits, und durch mehr Transparenz bei der Erfassung und Qualitätsbestimmung andererseits, bislang ungenutzte Produktivitätsreserven erschlossen werden. Dies würde die Attraktivität von Kleinbauern als Partner in vertragslandwirtschaftlich organisierten Märkten stark erhöhen.

Diese Studie ist im vietnamesischen Milchsektor, einem typischen Markt für hochwertige Agrarprodukte, angesiedelt. In Kooperation mit einem Molkereiunternehmen haben wir zunächst ein „Framed Field Experiment“ mit Milchbauern durchgeführt, in dem die Teilnehmer Entscheidungen treffen mussten, die eng an alltägliche Produktionsentscheidungen angelehnt waren. So haben wir verschiedene finanzielle Anreize hinsichtlich der Eignung im Kontext von Kleinbauern geprüft. Zudem haben wir ein einjähriges Feldexperiment mit denselben Milchproduzenten durchgeführt, bei dem zufällig ausgewählte Kleinbauern die Möglichkeit erhielten, die Milchqualität, die von der Molkerei mit Labormethoden bestimmt wird und gleichzeitig maßgebend für den individuellen Milchpreis ist, durch eine unabhängige Instanz überprüfen zu lassen. 
Für die Analyse der Experimente wurden mit Hilfe strukturierter Interviews detaillierte Haushaltsinformationen derjenigen Landwirte erhoben, die an den Experimenten teilgenommen haben. Darüber hinaus haben wir detaillierte Produktionsdaten aller Landwirte, die uns vom Molkereiunternehmen zur Verfügung gestellt wurden, genutzt.

Die Ergebnisse des „Framed Field Experiments“ unterstreichen die Effektivität von negativen finanziellen Anreizen wie sie aktuell im vietnamesischen Milchsektor Anwendung finden. Der Malus führt dazu, dass im Experiment mehr in Betriebsmittel investiert wird, was eine höhere Produktqualität zur Folge hat. Die Kombination von Malus und zusätzlichem Bonus, liefert ein noch besseres Ergebnis hinsichtlich der Produktion von hoher Qualität. Darüber hinaus zeigt sich, dass die Entscheidungen im Experiment von verschiedenen sozio-ökonomischen Charakteristika der Teilnehmer abhängen, wie z.B. Risikopräferenzen oder dem individuellen Wohlfahrtsniveau.

Das Feldexperiment liefert interessante Ergebnisse zur Wirkung von mehr Transparenz in der Lieferkette. Den Milchbauern die Möglichkeit einzuräumen, Milchprüfergebnisse des Molkereiunternehmens nachträglich zu kontrollieren, stellt eine effektive Möglichkeit dar, die Informationsasymmetrie hinsichtlich der Produktqualität zu beseitigen. So haben wir festgestellt, dass die Milchbauern 10 Prozent mehr Betriebsmittel verwendeten, was zu einer Steigerung der Milchproduktion führte. Bei Teilgruppen schlägt dies schließlich auch signifikant auf die wirtschaftliche Situation der Haushalte durch, die wir anhand der Haushaltsausgaben gemessen haben. Da im von uns untersuchten Fall das Molkereiunternehmen die Informationsasymmetrie, die vor unserer Intervention bestand, offenbar nicht zum 
eigenen Vorteil ausgenutzt hatte, half die unabhängige Qualitätsprüfung dem Unternehmen, ein nun glaubwürdiges Signal an die Landwirte zu senden, dass es ein fairer Geschäftspartner sei. Dies führte im vorliegenden Fall zu einer ParetoVerbesserung in der Lieferkette: Während die Produzenten direkt von gestiegener Produktivität profitieren, verbessert sich die Situation auch für den Milchverarbeiter, da sich die Transaktionskosten bei der Milcherfassung pro umgesetzter Einheit verringern.

Mit dieser Studie können wir zeigen, dass in landwirtschaftlichen Vertragssystemen finanzielle Anreize, die an die Lieferung von qualitativ hochwertigen Rohstoffen gebunden sind, ein geeignetes Mittel zur Koordination innerhalb der Lieferkette darstellen. Das ganze Potential können maßgeschneiderte Anreizsysteme, die auch auf spezielle Charakteristika von Kleinbauern berücksichtigen, allerdings nur dann entfalten, wenn gleichzeitig die Messung der Produktqualität durch den Käufer ausreichend transparent und nachvollziehbar gestaltet ist. In der Tendenz können die Ergebnisse für eine Reihe von landwirtschaftlichen Märkten, in denen Qualitätsattribute der Rohstoffe wertbestimmend sind, generalisiert werden, nicht nur in im Kontext von Vietnam, sondern auch darüber hinaus. 


\section{Acknowledgments}

I would not have been able to finish my dissertation without the outstanding support from a number of people. First and foremost I would like to thank my supervisor Matin Qaim. I am deeply indebted for his support, advice and patience during the entire four years it took me to complete my $\mathrm{PhD}$ studies, conduct the research and write up this thesis. I would also like to thank Máximo Torero who has not only introduced me to the art of applied research in the field but was also a great travel companion on numerous trips to Vietnam. Further I would like to thank my second supervisor, Marcela Ibáñez and my third examiner, Meike Wollni.

The field work would not have been possible without the support of Le Thi Phi Van and all colleagues at IPSARD in Vietnam. I also thank our project partners at Vinamilk, especially Vuong Ngoc Long for giving us the opportunity to carry out the experiments which provide the methodological framework of this study. Many thanks also to all dairy farmers who patiently took part in the experiments and three rounds of surveys.

During the field phase and several visits at IFPRI in Washington, DC, I had endlessly valuable and fruitful discussions with Angelino Viceisza and Trang Tran. I also would like to thank seminar participants at University of Göttingen and London School of Economics for their helpful comments which clearly improved my work. 
I am grateful to my current and former colleagues at Goettingen, Summer Allen, Christin Schipmann, Lisa Fischer, Cornelia Römling, Martin Noltze, Holger Seebens, Sylvia Schmidt, Jessica Torluccio and Joy Fabela from IFPRI.

Many thanks also to friends and family who have mentally supported me over the years. Thank you so much, Lita von Bieberstein, Klaus Erdle, Lara Averhoff, Christian Scheuring, all present and past Schildwegians, Stefanie, Volker and Florian Sänger as well as Ori Behr.

The financial support by the German Federal Ministry for Economic Cooperation and Development (BMZ) is gratefully acknowledged. 


\section{Table of contents}

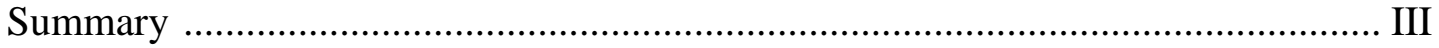

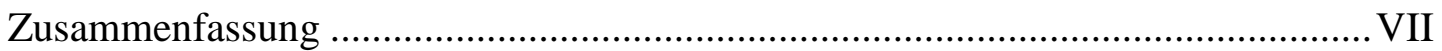

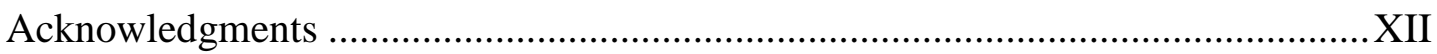

Table of contents................................................................................................ XIV

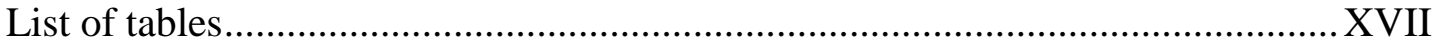

List of figures.............................................................................................

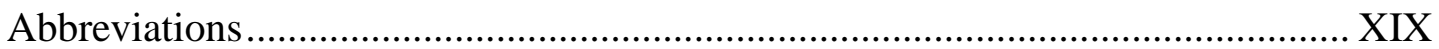

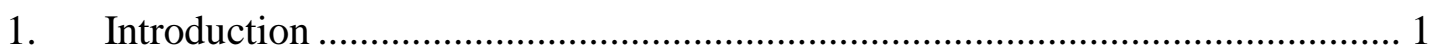

$1.1 \quad$ The agricultural value chain revolution .........................................................

1.2 Problem statement and objectives of the study .............................................

1.3 Outline of the dissertation.........................................................................

2. Theory of contracts and its application to agricultural markets .......................... 7

2.1 Make or buy decision and firm boundaries in the agribusiness.....................7

2.2 Contract design in agricultural markets ......................................................8

3. Field experiments in economics and applications........................................... 11

3.1 The "why" of field experimental approaches ...............................................11

3.2 The "how" of field experimental approaches ……………………………...13

3.3 Applications to agriculture............................................................................16

4. Research area and research design ............................................................... 18

4.1 The Vietnamese dairy sector.......................................................................18 


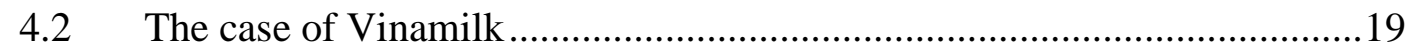

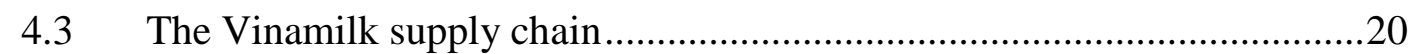

4.4 Research area and research design.......................................................21

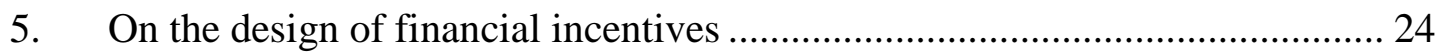

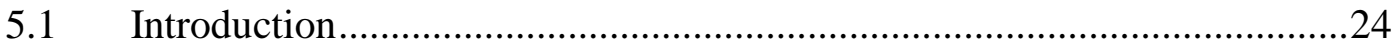

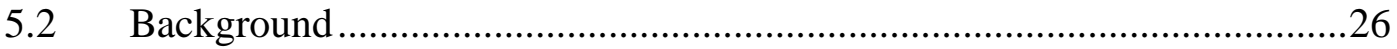

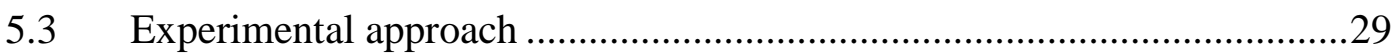

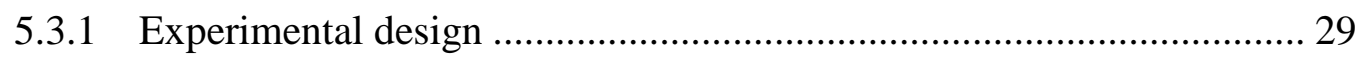

5.3.2 Sample selection and sample characteristics ..................................... 36

5.3.3 Implementation and procedures ...................................................... 37

5.4 Empirical strategy and comparative analysis..........................................40

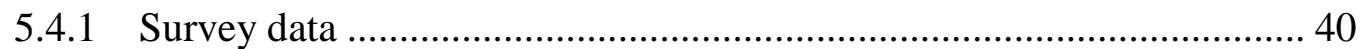

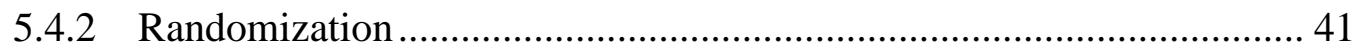

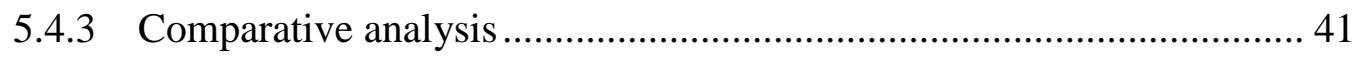

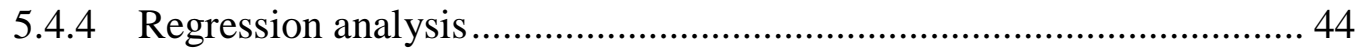

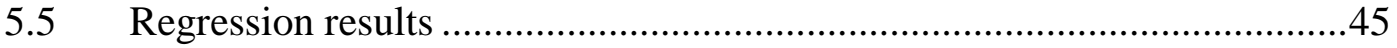

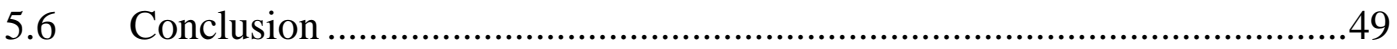

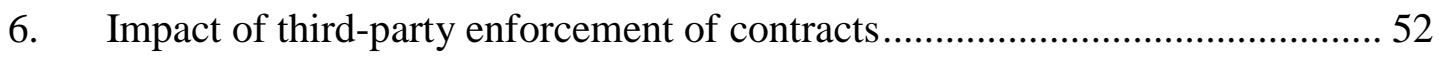

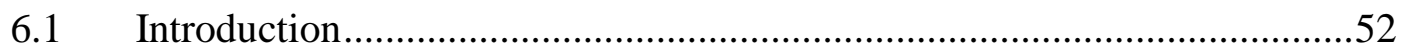

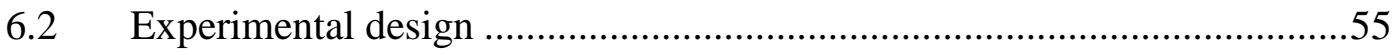

6.2.1 Background on the Vietnamese dairy industry .................................... 55

6.2.2 Supply-chain architecture and the standard contract .......................... 56

6.2.3 A simple model of underinvestment ...................................................58

6.2.4 Design of the intervention and implementation.................................. 61 
6.2.5 Study area, sample and randomization .............................................. 64

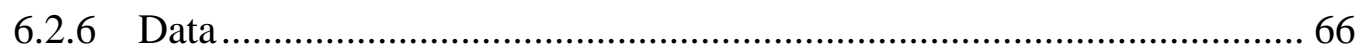

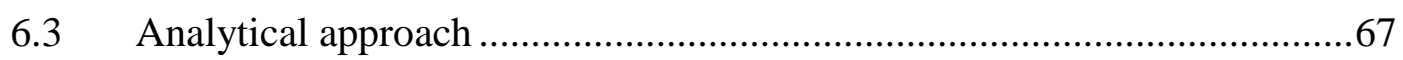

6.3.1 Identification strategy and econometric estimation ............................6 67

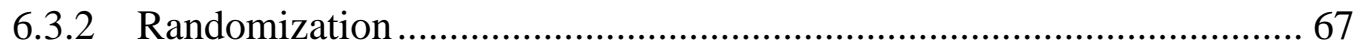

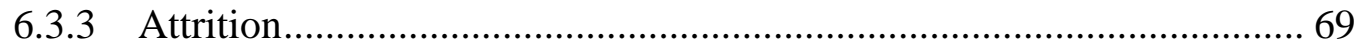

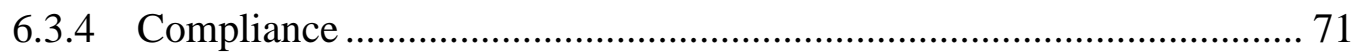

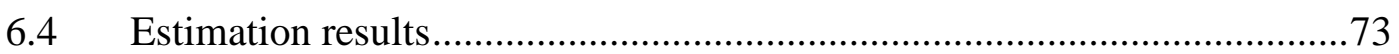

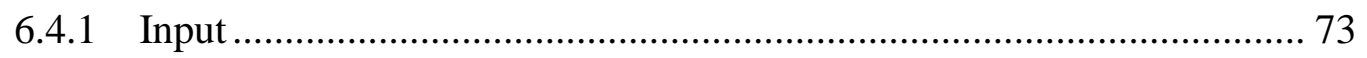

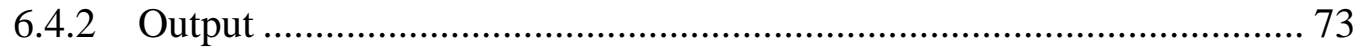

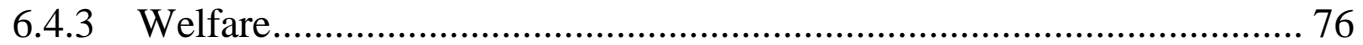

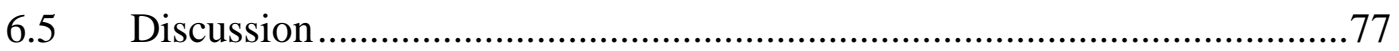

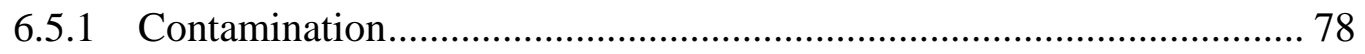

6.5.2 Data provision and incentive compatibility ....................................... 79

6.5.3 A story of moral hazard or signaling? ............................................... 82

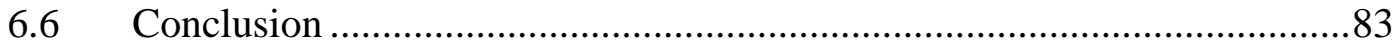

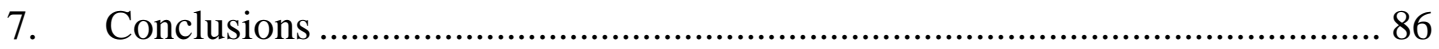

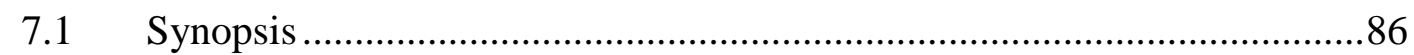

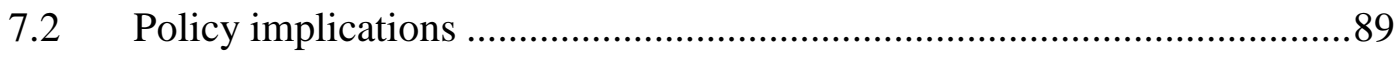

7.3 Limitations of this study and scope for future research .............................90

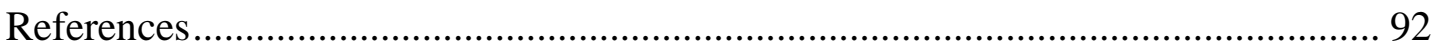

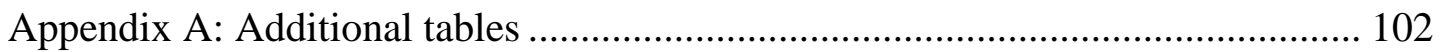

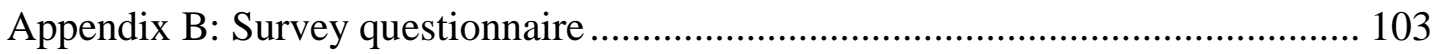




\section{List of tables}

Table 5.1: Payoff distributions by treatment in '000 VND.................................................32

Table 5.2: Sample means of selected characteristics by treatment....................................42

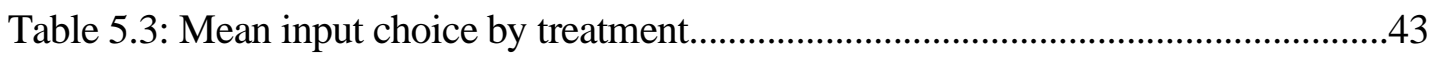

Table 5.4: Estimation results (random effects longitudinal tobit model)...........................46

Table 5.5: Additional estimation results (random effects longitudinal tobit model)........48

Table 6.1: Selected variables for treatment and control group ..........................................70

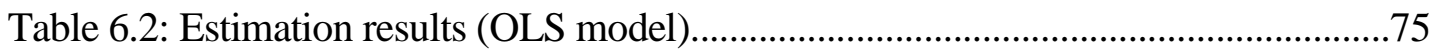




\section{List of figures}

Figure 3.1: Typology of experimental approaches in economics................................15

Figure 4.1: Milk production consumption in Vietnam (2003-2013)............................19

Figure 4.2: Stylized Vinamilk supply chain..............................................................21

Figure 5.1: Pricing scheme by treatment........................................................................

Figure 6.1: Farmers who have not executed a voucher evaluate the treatment $(n=86) . .72$

Figure 6.2: Stylized development of net-output levels for treatment group.....................81 


\section{Abbreviations}

$\begin{array}{ll}\text { AFE } & \text { Artefactual field experiment } \\ \text { ATT } & \text { Average treatment effect on the treated } \\ \text { EU } & \text { European Union } \\ \text { FE } & \text { Field experiment } \\ \text { FFE } & \text { Framed field experiment } \\ \text { HCMC } & \text { Ho-Chi-Minh-City } \\ \text { IPSARD } & \text { Institute of Policy and Strategy for Agriculture and Rural } \\ & \text { Development, Vietnam } \\ \text { NE } & \text { Natural experiment } \\ \text { RCT } & \text { Randomized controlled trial } \\ \text { TCE } & \text { Transaction cost economics } \\ \text { US } & \text { United States } \\ \text { USD } & \text { United States Dollar } \\ \text { VND } & \text { Vietnamese Dong (17,522 VND = 1 USD, July 2009) }\end{array}$




\section{Introduction}

Despite two decades of rapid economic growth in Asia and more recently also in parts of Africa, at the beginning of the $21^{\text {st }}$ century agriculture remains an important source of income in less developed countries, where around 65 percent of the population still engages in faming. Almost one third of the gross domestic product (GDP) in these countries is generated through agricultural activities (World Bank, 2007). Given its persistent economic significance for rural areas, where poverty and hunger are most widespread, the agricultural sector remains a pivotal element in designing strategies to improve the lives of billions of people in terms of food security and economic welfare.

Farming in developing countries is mostly small-scale, and producers face various agro-ecological, infrastructural and institutional constraints. Overcoming factors hampering farm productivity, such as lack of know-how or access to technology as well as to factor and product markets, has been identified as critical to progress in the farming sector (Doward et al, 2004; Hazell et al. 2010). The positive impact of policies targeting the modernization of the agricultural sector is not limited to farming households, though. Embedded in local communities, viable farming enterprises create positive spillovers through increased demand for goods and services provided by the local non-farm economy (de Janvry et al., 2002; Neven et al. 2009). Besides that, on-farm employment possibilities provide jobs in rural areas where underemployment is widespread. 


\subsection{The agricultural value chain revolution}

Beyond local food markets, high-value products have always played an important role for the agricultural sector in developing countries, especially for the export sector. This holds true for typical tropical commodities such as coffee, tea and cocoa, but also for fresh produce such as fruit and vegetables, for which export demand has grown recently (Jaffee, 1992; Wollni and Zeller, 2007; Maertens and Swinnen, 2009). During the last 20 years, additional factors have entered the equation: urbanization, increasing incomes and living standards, as well as the rise of a new urban middle class with westernized consumption habits have resulted in increased domestic demand for high-value agricultural products (Reardon et al., 2009; Mergenthaler et al., 2009). The share of high-quality calories from fruit and vegetables, meat and milk increases, a phenomenon which goes along with a rapid modernization of food value chains. Food items such as temperate-climate vegetables that were unknown only a few years ago, or dairy products which were not part of traditional diets in many Asian countries, find their way onto the shelves of supermarkets where urban dwellers increasingly do their grocery shopping (Fuller et al., 2006; Schipmann and Qaim, 2010).

The mushrooming of supermarkets serving this new type of customer can be observed in many low-income countries and has major implications for agricultural producers; farmers supplying these new market channels often have increased access to technological innovations leading to rising productivity levels, which can result in positive welfare implications for farming households (Rao et al., 2011). Supermarket chains and processing companies assume more control in the supply chain to satisfy the new urban middle classes' demand for healthy food items and to address 
consumers' concerns about threats to food safety arising from food scandals, such as the recent incidence of melamine-tainted fresh milk in China (Gale and Hu, 2009). As a result, agricultural supply chains in the high-value segment move from traditional procurement systems based on spot-market transactions to modernized procurement systems including a shift towards vertical integration and centralized procurement (Reardon et al. 2009). One approach buyers of raw material (e.g., wholesalers, processors) make use of is contract farming. Contracts enable buyers to exert more control over value chain relations, which is why they are becoming more and more prominent in high-value markets (Birthal et al., 2005; Swinnen, 2009).

Contract farming and vertical integration can take different forms, ranging from buyers and sellers relatively loosely connected through oral contracts to autocratic systems (Sykuta and Cook, 2001). Production contracts employing various integration strategies can be found for most high-value crops and livestock products (Reardon et al., 2009).

\subsection{Problem statement and objectives of the study}

The value chain revolution presents both opportunities and challenges to the agricultural sector, which in most developing countries is dominated by small-scale producers. In fact, this farm type is often characterized by high labor availability, a feature endowing smallholders with a competitive advantage in the production of labor-intensive high-value crops or livestock output (Weinberger and Lumpkin, 2007; Ashraf et al., 2009). However, the farm size seems to be a mixed blessing given evidence that smallholders become marginalized in modern supply chains-up to a point where they cannot benefit at all from the recent development of high-value agricultural product markets. Processors and wholesalers often prefer to source raw 
material from large farmers. Indeed, procurement from a great number of small-scale farmers leads to high per-unit transaction costs (Pingali, 2007). Yet, there are also examples of successful inclusion of farmers in modern supply chains enabling smallholders to greatly benefit from a combination of access to credit, inputs, improved technology, productivity effects as well as higher and more stable income (Masakure and Henson, 2005; Minten et al. 2009; Rao et al., 2011).

Hence, picking up Wiggin's et al. (2010) claim that smallholders have to interact effectively and economically with buyers in emerging high-value markets to protect a long-term perspective in the sector, the objective of this study is to identify ways to unlock small-scale farmers' potential to meet product quality requirements in contractual agreements and output productivity.

In contract farming arrangements, buyers often use output quality as proxy for effort exerted by farmers during the production process. Linking compensation to output quality helps to economize on monitoring costs and can incentivize production of high-quality output. However, there is little information on how to tailor contracts to fit smallholder environments. Hence, one challenge is to design effective financial incentives, taking into account specific characteristics of smallscale farmers, such as liquidity constraints and risk aversion (Fafchamps, 2003). A further challenge arises, if farmers' compensation is closely linked to output quality, as transparency of the system for quality measurement becomes increasingly important (Balbach, 1998; Sykuta and Cook, 2001). If product quality attributes are observable to the buyer but not to the selling farmer, opportunistic buyers could report lower than actual output quality, negatively affecting farmers' compensation. If farmers assume buyer's potential opportunistic behavior, they may underinvest, 
i.e. use suboptimal amounts of input, limiting farm productivity (Gow et al., 2000; Vukina and Leegomonchai, 2006; Cungu et al., 2008).

Hence, freeing these yet untapped or blocked productivity reserves of smallscale farmers is a key factor in raising their attractiveness as contract partners with the aim of increasing smallholder participation in high-value markets. Using the example of the Vietnamese dairy sector, which is an interesting case of a fast growing high-value market in a developing country, we employ field experimental approaches to investigate the effectiveness of financial incentives in inducing the production of high quality output, and to look into the benefits arising from enforcement of yet incomplete contracts.

Specifically we formulate the following research objectives:

(1) Identifying which type of financial incentive, penalty or bonus or a mixture of both, works best under smallholder conditions by dissecting specific contract designs with respect to their incentivizing effect.

(2) Assessing the impact of third-party enforcement of contracts on farmproductivity and welfare of sellers and buyers by examining the importance of transparency in contractual arrangements.

\subsection{Outline of the dissertation}

This study is organized as follows. In Chapter 2, the theoretical framework of contracts and applications to agricultural markets, including examples of integration strategies, are presented.

Since the empirical part of this investigation relies on experimental economic approaches, in Chapter 3, we explain this particular research methodology and define the scope of the two approaches we use. 
In Chapter 4, information on the role of milk consumption in Vietnam and the domestic dairy sector is presented. Further we describe the research area and design as well as the data we use and how we obtained it.

In Chapter 5, addressing the first research objective, financial incentives are evaluated with respect to their potential in incentivizing production of high quality output. We conduct a framed field experiment testing various financial incentives and compare how well they induce exertion of effort. The experimental choice data is complemented with information obtained from a household survey carried out with the participants of the experiment beforehand and detailed milk output data provided by the collaborating dairy processor.

In Chapter 6, addressing the second research objective, the impact of thirdparty enforcement of contracts is investigated. Using the same sample of farmers we carry out a field experiment in which we provide dairy farmers with the opportunity to verify milk quality testing results provided by the buying firm. The impact of more transparency in the supply chain is quantified using data obtained through comprehensive household surveys carried out before and at the end of the intervention. This information is complemented with detailed milk output data provided by the collaborating dairy processor.

We conclude in Chapter 7 by distilling the main findings to policy recommendations, and outlining avenues for future research. 


\section{Theory of contracts and its application to agricultural markets}

\subsection{Make or buy decision and firm boundaries in the agribusiness}

Make or buy decisions in commercial organizations play a central role in Transaction Cost Economics (TCE) and often determine firm boundaries. Williamson (1979) has pointed out that the foremost criterion applied in organizing commercial transactions is the cutting down of production and transaction costs. Accordingly, firms tend to opt for buying a good rather than making it if internal production costs are high while transaction costs procuring the item from outside are low. Make or buy decisions are also highly relevant in agricultural markets in which firms such as wholesalers or processors could either engage in farming themselves (through direct investments in farms or farmland) or alternatively procure agricultural produce from the market through some sort of institutionalized economic transaction.

Sykuta and Cook (2001) emphasize several main factors determining the organizational form of buyer-seller relations. Applying Williamson's TCE framework to the agricultural sector, Sykuta and Cook emphasize the role of assetspecifity and bounded rationality in situations with opportunistic decision behavior as well as complexity, uncertainty and frequency of the economic transaction.

After individually appraising and weighing these factors, decision makers at firm level who opted for buying instead of making, work out a specific form for the 
economic transaction, ranging from anonymous, one-time spot-market purchases to long-term contractual relations with fully specified terms (Sykuta and Cook, 2001).

\subsection{Contract design in agricultural markets}

Markets for high-value agricultural products entail several characteristics calling for more control on the side of the buyer, making spot-market transactions less likely:

First, consumers develop rising expectations towards visible quality attributes (search attributes) such as shape, color and freshness but also non-visible ones (experience and trust attributes) like process quality of food items. Growing highquality produce is complex and often requires farmers to use specific production technology and follow certain agronomic practices. To assure that farmers comply with such rules, processors and wholesalers may have to engage in close monitoring of production processes or use other incentive instruments (Hueth et al., 1999).

Second, buyers (e.g., processors, wholesalers) need to assure that the often highly perishable produce is delivered at specific times to assure a constant flow of raw material into capital-intensive processing plants or onto supermarket shelves (Kirsten and Sartorius, 2002).

Contract farming is one approach to meet the increasing demand for control and coordination in the value chain. The form of contractual arrangements between buying firms and selling farmers vary in terms of their integrating function. A central element of most contracts is the output price. In fixed-price contracts, producers are insulated from price changes on the (world) market as price risk is shifted to the buyer. To protect quality, fixed-price schemes oftentimes entail financial bonuses or penalties conditional on the actual product quality delivered (Goodhue et al., 2004). 
The optimal design of financial incentives, that are conditional on output quality, will be studied in detail in Chapter 5 .

However, when farmers' compensation is linked to quality attributes, transparency with respect to the nature of the system for quality assessment is crucial. This becomes especially important if the buying firm is not inherently producer oriented, as in the case of processing companies which are investor-owned rather than producer-owned as proposed by Balbach (1998). Even if the financial incentives are well designed, the contract will yield only suboptimal outcomes if farmers believe that the contracting firm does not correctly compensates their effort and adjust their input decisions accordingly. We will address this aspect in Chapter 6.

Besides the output price, more generally, Hueth et al. (1999) name monitoring, input control, quality measurement and residual claimancy as potential solutions to the coordination problem. For developing countries, direct provision of inputs and know-how as well as credit can be important as market imperfections constrain smallholders in meeting quantity and quality goals set in the contract (Bellemare, 2009).

All coordination strategies named above may be effective in increasing buyers' control but also have a non-trivial flip side. For example, monitoring, input control and measurement turn out to be very costly for the buying company, especially in a smallholder context. If the farm output is collected and graded in small batches, procurement cost inevitably goes up. Also processing payments for and managing contracts of a great number of small-scale farmers can be a significant administrative burden. 
Under specific circumstances the degree of control reached by administratively costly, fully specified contracts may still not suffice. Farmers might simply renege on the contract and sell their produce elsewhere if a price premium can be realized for selling on the spot-market. This threat is especially real in environments with weak legal institutions; contracting firms may have considerable difficulties to effectively enforce contractual agreements or apply penalty mechanisms.

However, weak institutions and poor governance can also negatively affect small-scale farmers. Atomistic supplier structure, low degree of organization in cooperatives or farmer groups and relation-specific investments required in many high-value markets reduce smallholders' bargaining power and may result in hold-up problems (Gow and Swinnen. 1998). For example, dispute settlement regarding product quality is often no realistic option when independent assessment is not available.

In this thesis we study existing ${ }^{1}$ written contractual arrangements between a dairy processor procuring raw milk from small-scale farmers in Vietnam. We hypothesize that the contract in its current form leaves room for improvement to more effectively incentivize the production of high quality output. Our empirical approach, which looks into ways of optimizing the contractual relationship to generate gains from improved coordination, relies on experimental methods explained in more detail in the next chapter.

\footnotetext{
${ }^{1}$ The fact that we investigate an existing contract implies that, in the language of agency theory, both the participation constraint and the incentive compatibility constraint are met (Rasmussen, 2007, p. 194). Otherwise, the contract between the buying firm and the selling farmers would not have been signed in the first place.
} 


\section{Field experiments in economics and applications}

In this chapter, we briefly introduce field experimental approaches, which have been widely embraced by development economists and also constitute the methodological framework of this study. After addressing why field experimental approaches have become prominent in policy evaluation and testing of economic theory, we will get to the "how", i.e. discuss typical designs in general but also applications to agriculture. Briefly touching upon different variants of experiments in the field we will also contextualize the two types of experiments conducted as part of this thesis. We revisit both experiments in greater detail in Chapters 5 and 6 .

\subsection{The "why" of field experimental approaches}

Field experimental approaches, which regarding their underlying principles resemble laboratory methods or clinical trials that scientists have been using for decades, have become an integral part of the methodological arsenal of development economists. The key motivation for designing and implementing experiments is the empirical researchers' quest for truly exogenous variables in the study of economic processes (Harrison and List, 2004). Using typical observational data obtained through household surveys, researchers usually face biases that create a serious challenge for subsequent analyses. For example, in measuring the effect of information on the outcome of economic interactions, selection bias may lead to under- or overestimation of the role of information if specific characteristics, which 
are correlated with the outcome of interest, make certain individuals or households more likely to access the information than others. Ubiquitous biases require economists analyzing observational data to apply sophisticated econometric methods such as matching techniques, instrumental variable approaches or structural modeling which oftentimes impose fairly strong assumptions.

If, however, the informational status (e.g. "high” or "low”) of the individual or household is independent of individual or household characteristics, e.g. through ex-ante random assignment of the information status (or more generally the treatment status), the information status (treatment status) is truly exogenous (orthogonal) to the outcome variable of interest. Hence, random assignment helps to avoid selection bias; as result in this example the treatment effect (impact of information) is well identified. Any observed differences in the outcome variable between treatment and control group, i.e. groups with "high" and "low" information, can be fully attributed to the informational differential (treatment).

A further advantage of experimental approaches is that researchers can induce variation to address research questions in situations where typical observational data usually suffers from low-variation, limiting the scope for statistical analyses. For example, in the field of contract farming, studying the effectiveness of differently structured contractual arrangements is hampered by the fact that buying firms usually offer only one type of contract at a time (Alexander et al., 2007). Hence, there will be no variation with respect to incentive instruments used if all farmers in a dataset are exposed to the same contract, making it difficult to draw conclusions on the effectiveness of incentives. In the (field) laboratory, though, researchers can induce variation by designing different treatments, and randomly assign subjects to 
treatment groups. We take advantage of the possibility to induce variation in the experiment described in Chapter 5.

\subsection{The "how" of field experimental approaches}

Based on Harrison and List (2004) we propose a taxonomy of relevant field experiments, which, in their words, "leaves gaps” but is useful for our purpose of contextualizing the two approaches we use in this study. In their article, Harrison and List propose six factors by which the "field context" of an experiment can be characterized: (1) the nature of the subject pool, (2) the nature of the information that the subjects bring to the task, (3) the nature of the commodity, (4) the nature of the task, (5) the nature of the stakes, and (6) the nature of the decision environment.

In Figure 3.1, the most widely used variants of experiments are presented and contrasted based on the underlying data type. For illustrative purposes, conventional laboratory experiments and natural experiments are included in the figure, representing the extreme points on the stratum of experimental approaches, albeit they do not fall in the category of experiments in the field in a narrow sense. Besides that, frequently used econometric approaches named above are also listed to complete the picture.

Starting on the extreme left side of the stratum that indicates the degree of control assumed over the data generating process, we skip the classic laboratory experiment and start the discussion with the field experimental approach that promises the highest degree of control: the artefactual field experiment (AFE). AFE resembles the lab experiment in all dimensions (e.g. abstract framing of the decision task) except that the participants in the experiment are recruited from a non-standard subject pool, which—and this is noteworthy—is the common denominator of all 
field experimental approaches. While participants in laboratory experiments are usually recruited from populations of college students (commonly referred to as standard pool), subjects in field experimental approaches are purposefully sampled from a non-standard pool representing the target population in the economy. Two examples for artefactual field experiments are those of Harrison et al. (2002) who carried out experiments in Denmark with a nationally representative sample of subjects to estimate individual discount rates, and Gächter and Herrmann (2011) who conducted public goods experiments with participants in Russia, assuming that the long history of collectivism had an impact on voluntary cooperation.

Framed field experimental approaches (FFE), which we use in this study (Chapter 4), are similar to artefactual field experiments. But in addition to a nonstandard subject pool, FFE are characterized by less abstract framing, often including choice tasks mimicking day-to-day decisions as well as more tangibly defined commodities. For example, studying the effectiveness of policies on coca investment, Ibáñez and Martinsson (2008) conducted a framed field experiment in which smallholders in Colombia had to take hypothetical agricultural investment decisions.

The nature of stakes in lab and field experimental studies has been subject to a longstanding debate. Experiments in high-income countries have been frequently criticized, because—-due to budget constraints—stakes were relatively low, raising the concern that incentive structures in (laboratory) experiments would not reflect field conditions well. This was confirmed by high-stakes experiments carried out in both low- and high-income countries (Kachelmeier and Shehata, 1992; Holt and Laury, 2002). These findings demonstrate the appeal of carrying out field 
experiments in low-income countries, as the researcher can run experiments with non-trivial stakes despite typical budget constraints.

\begin{tabular}{|c|c|c|c|}
\hline \multicolumn{3}{|c|}{ Controlled Data } & Naturally-Occuring Data \\
\hline $\mathrm{Lab}$ & FFE & $\mathrm{FE}$ & NE, PSM, IV, STR \\
\hline $\begin{array}{l}\text { - Lab: } \\
\text { - AFE: } \\
\text { - FFE: } \\
\text { - FE: } \\
\text { - NE: } \\
\text { - PSM: } \\
\text { - IV: } \\
\text { - STR: }\end{array}$ & $\begin{array}{l}\text { Laboratory experim } \\
\text { Artefactual field ex } \\
\text { Framed field experi } \\
\text { Field experiment / } \\
\text { Natural experiment } \\
\text { Propensity score est } \\
\text { Instrumental variab } \\
\text { Structural modeling }\end{array}$ & tion & \\
\hline
\end{tabular}

Source: Based on Levitt and List (2009)

Figure 3.1: Typology of experimental approaches in economics

An ideal laboratory setting allows the researcher to minimize noise in the decision task, as the only varying factor is the "stressor" the researcher is interested in (Harrison and List, 2004). In contrast, if experiments are taken to the field there is usually more noise, for example due to relationship between subjects and the decision environment, e.g. the experimental site.

In terms of the decision environment there are major differences between artefactual and framed field experiments on the one hand, and field experiments (FE) — the final experimental approach we discuss here-on the other hand. The former have in common that the experiments are usually carried out in classrooms (or appropriate substitutes) in the communities where the subjects are located. These experiments have a short and clear-cut time frame: Subjects usually take part in 
multi-round games or complete a battery of decision tasks and leave the experimental site afterwards.

For FE, which initially were a tool to evaluate policy interventions, this is vastly different. FE are also called randomized controlled trials (RCT), and we use these terms interchangeably. RCT usually imply a costly large-scale intervention changing specific parameters, e.g. with respect to health (e.g. de-worming programs) or education (e.g. provision of text books) that affect people's daily life. They usually last for several weeks, months, or even years. Detailed socio-economic data of the participants are collected for subsequent impact analyses. A typical example is the much cited randomized evaluation of the conditional cash transfer program PROGRESA in Mexico (Skoufias, 2001). However, more recently RCT graduated from mere impact evaluation approaches to bespoke tools designed to study fundamental problems in economics such as the role of incentives, social learning or inconsistent time preference (Duflo, 2006).

One major advantage of RCT is that they fully reflect the complexity of decisions and interactions in the real world. For example, under field conditions decisions may be made at household or group level (e.g. in a firm), involving complex bargaining processes, which are difficult to simulate in the laboratory (Harrison and List, 2004).

\subsection{Applications to agriculture}

In mainstream economics, experimental approaches (lab, artefactual field, framed field, and RCT) have been employed to investigate a broad range of problems. For some time already, experiments have been carried out in rural areas of developing countries, initially with the intention to solve the problem of trivial stakes 
(Binswanger, 1980). The research questions that were intended to be solved, however, were just remotely related to agriculture. Only recently field experimental approaches have been used to address specific problems in agricultural economics, such as adoption of innovations or access to markets (Lybbert, 2005; Ashraf et al., 2009; Duflo et al., 2011, Hill and Viceisza, 2011).

Especially in studying agricultural contracts—besides using standard observational data—researchers so far have relied on laboratory experiments ( $\mathrm{Wu}$ and Roe, 2005; 2007). Hence, to the best of our knowledge, for the first time, we employ field experimental methods to study contracts in agriculture. Specifically, we employ framed field experimental (Chapter 5) and RCT approaches (Chapter 6). 


\section{Research area and research design}

\subsection{The Vietnamese dairy sector}

Over the past two decades the Vietnamese economy expanded at an average annual growth rate of roughly 4.5 percent. Over the same time period the share agriculture contributes to the GDP declined from 42 percent in 1989 to 22 percent in the year 2010 (ADB, 2008, CIA, 2012). A quarter of the GDP generated in the agricultural sector stems from livestock farming (FAO, 2005). Growth in the increasingly important dairy sub-sector is fueled by rapidly increasing domestic demand for milk products. For example, only twenty years ago the consumption levels of milk and dairy products in Vietnam were almost zero, while annual percapita consumption had reached already $15 \mathrm{~kg}$ in 2010 (USDA, 2011).

Currently, large quantities of powdered milk are imported from overseas to satisfy the local demand Vietnam. However, more and more milk is produced domestically where production has more than tripled between 2003 and 2009, now reaching almost 300,000 tons per annum. Today, roughly a fifth of consumption in Vietnam is met by local production, mostly sourced from smallholders (Figure 4.1). The Vietnamese government prioritizes the development of local dairy production, reflected by the National Dairy Development Plan, a set of policies with the goal of tripling the number of dairy cows in Vietnam until the year 2020 in order to keep up with ever growing local demand for milk and milk products (USDA, 2011). 


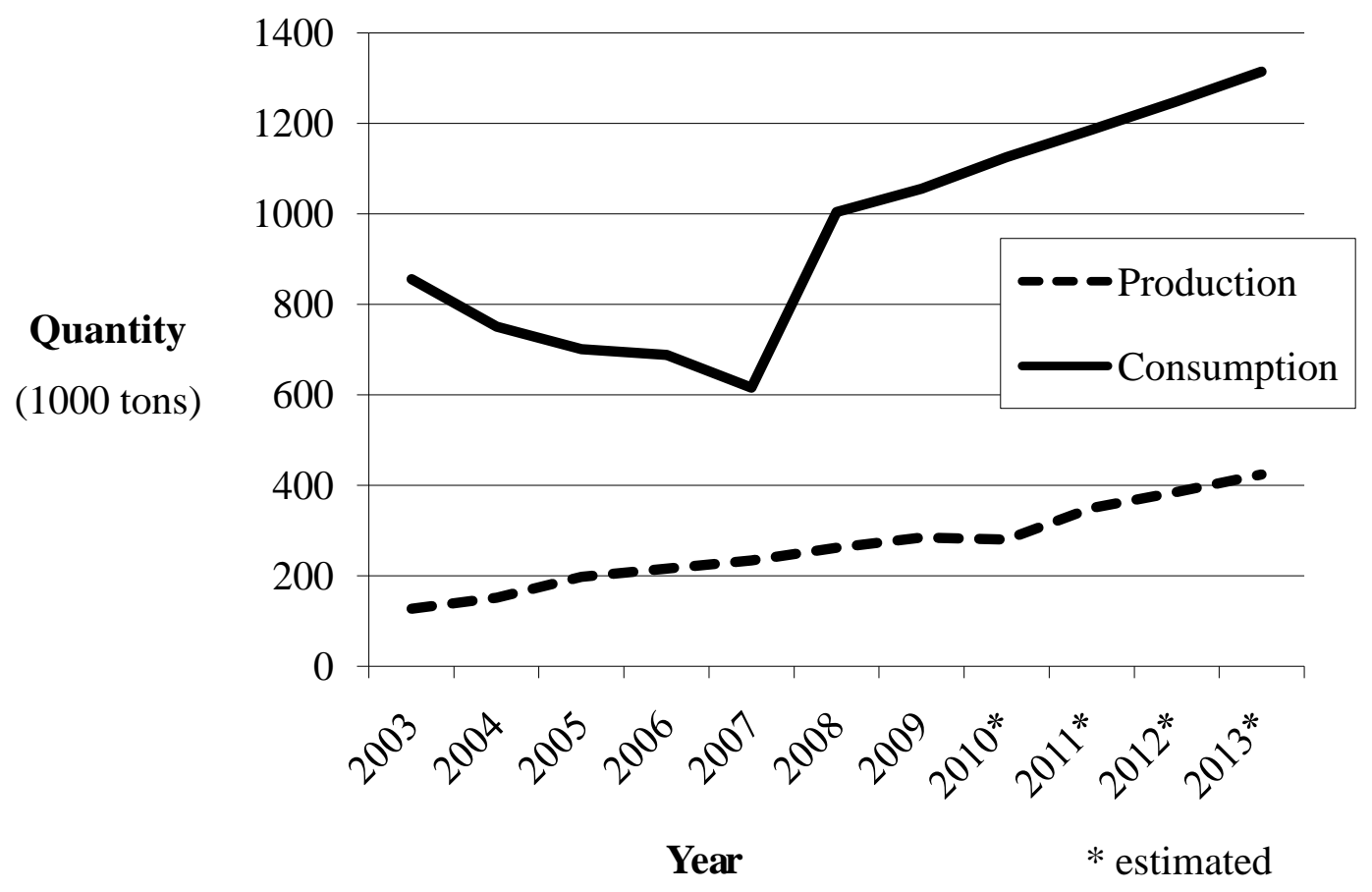

Figure 4.1: Milk production consumption in Vietnam (2003-2013)

Source: USDA (2011)

\subsection{The case of Vinamilk}

Today, the Vietnamese dairy sector is dominated by the formerly state owned processing company Vinamilk. Its product portfolio comprises fresh milk, condensed milk, milk powder including infant formula, yogurt and ice cream. Vinamilk obtains raw material from three different sources: First, through contracting around 5,000 small-scale dairy farmers; second, through production of milk on own large-scale dairy farms; and third, by importing powdered milk.

Vinamilk collects around 60 percent of the milk produced in Vietnam (USDA, 2011). Milk production takes place mainly in a belt around Ho-Chi-Minh City (HCMC), the greater Hanoi area and the central highland province Lam Dong. Besides procuring from smallholders, Vinamilk also runs two own large-scale farms 
with 2,000 dairy cows each, planning further expansion. Taken together, the milk sourced from small-scale farmers and own production, makes up only 30 percent of Vinamilk's total demand of raw material. The remaining share has to be imported from New Zealand, Australia, the US and the EU, mainly as powdered milk.

\subsection{The Vinamilk supply chain}

Figure 4.2 depicts the structure of the dairy supply chain: Milk is produced by smallholders with an average herd size of 3 to 5 heads per farm in the North and 5 to 7 heads in the South (1). The annual milk yield per cow is low, reaching on average 4,500 kg (USDA, 2011). The raw milk is channeled through nationwide almost 90 milk collection centers (MCC) which are located in the farming communities (2). Upon farmers' arrival at one of the MCCs, which are managed by private entrepreneurs, external Vinamilk staff carries out first tests of sensory properties and analyses to detect antibiotics or water mixed into the milk. These checks are decisive for acceptance or refusal of the milk. The raw milk of all farmers is temporarily stored in a cooled tank and on a daily basis transported by truck to the next dairy (3). The individual milk samples of the same day are also sent to the dairy plant for subsequent laboratory analyses of milk fat and total solid, the main parameters determining the milk price (4). Despite the limited production capacity of smallholders under contract, Vinamilk compensates each farmer based on the milk quantity and quality delivered. Once a week, milk analyses of milk fat and total solid are carried out individually for each producer to assess output quality. Based on the results of these milk tests, farmers are compensated. Farmers are paid a base price for milk of highest quality which is gradually adjusted downwards, if milk quality fails to meet the requirements set by the processor. On behalf of Vinamilk the MCCs 
process the weekly cash payment for the milk farmers had delivered during the preceding week (5). The MCC operator receives a commission based on the amount of milk procured and transported to the dairy factory. Up to the point when the milk arrives at the Vinamilk factory gate, the MCC has to bear all risks related to procurement and transport.

1
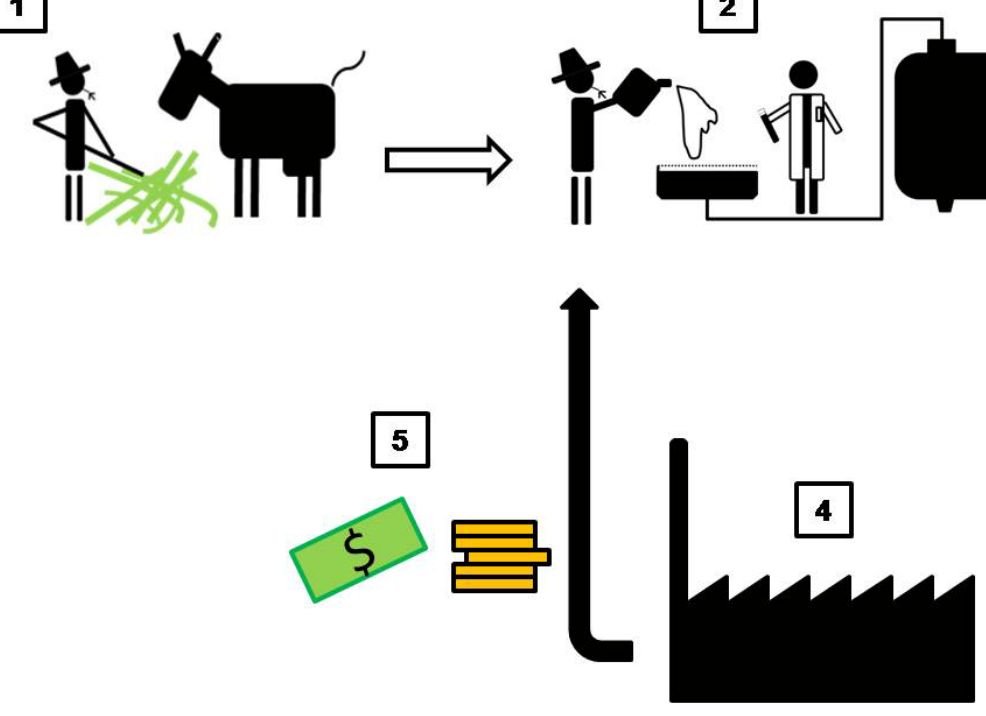

2
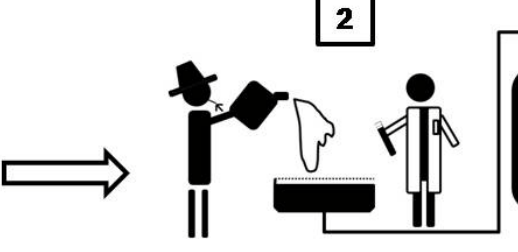
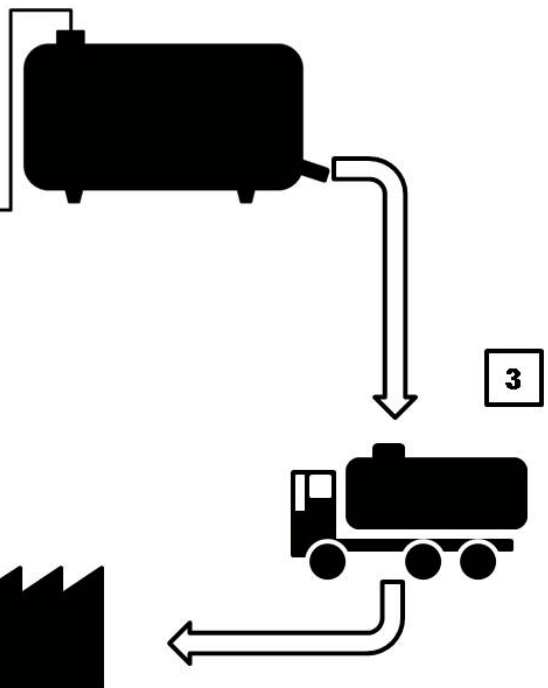

Figure 4.2: Stylized Vinamilk supply chain

Source: Own data

\subsection{Research area and research design}

This study was conducted in two provinces, Long An and Tien Giang, located 60 kilometers south and west of HCMC, the commercial hub of Vietnam. According to USDA (2011) more than two thirds of the dairy cows in Vietnam are kept in the HCMC region. Hence, with respect to agro-ecological conditions these provinces represent typical milk producing areas. Vinamilk provided us with a comprehensive 
list of 402 farmers all of whom were contracted by the company, supplying their milk to four different MCCs in their communities.

From the population of 402 farmers, in May 2009, we first randomly sampled 205 subjects to take part in a framed field experiment (see also Chapter 5). In a second wave 202 farmers were assigned to participate in a RCT (see also Chapter 6). The framed field experiment was carried out in June 2009. The RCT was implemented between May 2010 and April 2011. The sampling method we used implies that some of those subjects who took part in the framed field experiment were also participating in the RCT.

We collected household data for all 402 dairy farmers on the list provided by Vinamilk. Between 2009 and 2011 we carried out two structured surveys, a baseline survey in April/May 2009 and a follow-up survey in May/June 2011, enabling us to thoroughly evaluate both the framed field experiment and the RCT.

The survey was conducted in cooperation with the Institute of Policy and Strategy for Agriculture and Rural Development (IPSARD), located in the Vietnamese capital, Hanoi. We developed structured questionnaires which were generally similar during all two rounds of surveys. The survey instrument contained modules to collect data in the following domains: (i) Socio-demographic information such as age, gender and education of household members, (ii) socio-economic data on income-generating activities, expenditures and assets, as well as (iii) data related to altruism, trust, risk- and time-preferences. The questionnaires were thoroughly tested under field conditions during one week of pretesting.

The survey was carried out by a team of up to twelve enumerators and supervisors who at that time were affiliated to IPSARD. All enumerators and 
supervisors held undergraduate and partially graduate degrees in agronomy or agricultural economics. Before the surveys started, the team was trained in three day workshops. Completing one survey round took roughly 20 days in the field. The interviews were carried out using a Vietnamese version of the questionnaire. The original English version of the questionnaire (second follow-up survey) is included in Appendix B.

The household data were complemented with high-resolution farm level output data. Vinamilk provided information in spread-sheet format on weekly milk quantity and quality delivered as well as the milk price for each farmer in the sample. The data covered the time period stretching from May 2008 until May 2011. 


\section{On the design of financial incentives}

\subsection{Introduction}

The rapidly increasing demand for high-value food products in developing countries is triggering important changes in traditional supply chains, which often involve smallholders (Reardon et al., 2009). Processors and wholesalers, who are looking for new and efficient ways to source high quality raw material, have widely embraced contract farming as one approach to coordinate supply chain relations (Birthal et al., 2005; Swinnen, 2009; Schipmann and Qaim, 2011). Production contracts can entail a broad variety of incentive instruments, such as input control, field visits, quality assessment, and incentive pay, all of which aim at maintaining high output quality (Hueth et al., 1999; Bellemare, 2010).

Empirical evidence on the degree and impact of smallholder participation in high-value markets is mixed. Some studies find that buyers prefer to contract larger farmers because of lower transaction costs (Key and Runsten, 1999). However, there are also examples where smallholders benefit from contract farming through better access to inputs and technology as well as higher and more stable prices (for a comprehensive review, see Minten et al., 2009). Small-scale farmers can have a comparative advantage in the production of labor-intensive goods. Yet, they may struggle to meet strict quality standards, especially when these require the use of special inputs or new production techniques (Swinnen, 2009). Given widespread constraints, smallholders may underinvest into their production, which can result in 
suboptimal quality from the point of view of buyers in high-value markets. Improved contracts could potentially help reduce transaction costs and provide new incentives for high-quality production. However, there is very little empirical evidence available on issues of contract design in a small farm context.

The available literature on contracts in agriculture focuses mainly on two questions: first, what determines contract choice (Ghatak and Pandey, 2000; Goodhue et al., 2004; Masakure and Henson, 2005) and second, how do specific contract designs affect farmers' response once they have been contracted by a buyer (Hueth et al., 1999; Goodhue et al., 2010)? The second question has mostly been addressed in developed countries. For example, studies in the markets for processing tomatoes and wine grapes in the US have found that financial incentives can successfully influence production decisions and increase quality (Goodhue et al., 2004; Alexander et al., 2007). However, the empirical analysis of both, contract choice and performance under a specific contract type, can be confounded by selection bias, as most farmers choose only one type of contract, and this choice may be endogenous (Alexander et al., 2007). One way to avoid the endogeneity problem is the use of experimental methods to observe behavior under controlled conditions. In an early study, Bull et al. (1987) have experimentally tested various contracts. Wu and Roe (2005) have investigated different incentive schemes employed in contract agriculture using laboratory experiments with college students in the US.

We contribute to this literature through a framed field experiment carried out with farmers in a developing country. In particular, we are interested in the relationship between price incentives, input use, and output quality in contract arrangements. The experiment was conducted with a subject pool of smallholder 
dairy farmers in Vietnam. The Vietnamese dairy sector is a typical example of fast growing high-value markets in developing countries, where the quality of the raw material becomes increasingly important. For example, high content of psychrotrophic bacteria or antibiotics in the raw milk caused by poor herd management can increase processing costs (Claypool, 1984), while adulteration of milk along the supply chain can have adverse health effects for consumers, as the recent case of melamin-tainted milk in China has shown (Gale and Hu, 2009).

The Vietnamese dairy farmers that participated in our experiment produce milk under a contract with a large processing company. We have designed three input decision games with varying financial penalties and a bonus to investigate (i) whether the incentive structure in the existing contract effectively incentivizes input use to boost output quality and (ii) whether, additionally to the financial incentive, risk preferences and wealth levels drive farmers' input decisions. Based on the findings we discuss ways to improve existing production contracts to the benefit of both smallholders and processing companies.

The remainder of this chapter is organized as follows. After presenting some background information on contract farming in the Vietnamese dairy sector in Section 5.2, the experimental approach is described in Section 5.3. The empirical strategy and descriptive statistics are outlined in Section 5.4, followed by the presentation and discussion of regression results in Section 5.5. Section 5.6 concludes with some policy and research implications.

\subsection{Background}

The market for dairy products in Vietnam has a couple of features that are typical for emerging high-value markets in developing countries. First, it has high 
growth rates. Only two decades ago, the consumption of milk and dairy products was almost nil in Vietnam (and other Asian countries) due to cultural practices and low income levels. But economic growth, urbanization, and the spread of Western lifestyles went along with a change in food consumption patterns, causing a surge in the demand for milk. Today's per-capita consumption of milk has reached $15 \mathrm{~kg}$ per annum in Vietnam, which is still only about 8 percent of what is consumed in the US or Europe (USDA, 2011).

Second, the Vietnamese dairy sector is dominated by local processing companies, which currently import large quantities of powdered milk from overseas to satisfy local demand. However, increasing quantities are produced domestically, especially by small-scale farmers. Fresh milk production in Vietnam has more than tripled between 2003 and 2009, now meeting about 20 percent of domestic consumption (USDA, 2011). Third, the quality of the raw material is very important for processing companies that mainly sell drinking milk, yoghurt, ice cream, and infant formula. Powdered milk from the world market is a standardized product, which is purchased in large batches with known and predictable quality. In contrast, local farmers produce small quantities of raw milk, which is subject to fluctuation in quality, depending on various factors.

To ensure a constant supply of raw material, dairy processors in developed and developing countries do not source raw milk from spot markets but through contract farming arrangements (e.g., Royer, 2011). Until recently, it was quite costly to assess milk quality for each farmer, especially when only small quantities are involved. Today, cheaper quality testing devices allow dairy processors to assess quality individually for each farmer, which is a key requirement for traceability, 
quality management, and incentive pay. The question is as to how farmer-specific quality data can be used to design incentive-compatible contracts. In Vietnam, the largest dairy processing company utilizes the data to employ financial penalties, punishing the delivery of poor quality. A base price is paid for milk of the highest quality. For lower quality, the company adjusts the price downwards. Milk quality is a function of farmers' input use and environmental factors. Hence, dairy farmers face the challenge to maximize profit by choosing the right input mix to produce a specific quality. This decision involves some degree of risk, because environmental factors are not perfectly predictable. This situation is also the starting point for our framed field experiment.

The current design of the contract in Vietnam has evolved over time. The instrument of financial penalty has to be seen in the context of the existing market structure. For most dairy farmers, the processing company is the only realistic marketing option. The raw milk is perishable, and production involves a high degree of asset specificity, so that farmers' bargaining power is limited. Here, we are not primarily interested in analyzing whether or not the pricing scheme in the existing contract is fair. Rather, we want to understand how it affects farmers' input use and their incentive to produce high quality. Various studies on the consequences of oligopsony power suggest that biased pricing can affect farmers' investment behavior (Gow and Swinnen, 1998; Young and Hobbs, 2002; Vukina and Leegomonchai, 2006; Swinnen and Vandeplas, 2010). This can include both shortterm investments into variable inputs and also longer-term investments into technological upgrading. 


\subsection{Experimental approach}

\subsubsection{Experimental design}

We have designed a framed field experiment, which involves five repeated costly choices between three gambles. Specifically, the subjects (dairy farmers) choose input levels mimicking risky day-to-day production decisions familiar to them from their own farm. In the game, each subject hypothetically owned one cow that produced a fixed quantity of milk (10 kg per day) with varying quality. Milk quality is graded in five levels, A to E, each yielding a different price. The base price chosen for the experiment was 7,000 Vietnamese Dong (VND) per kg for quality A. Lower quality grades were associated with severe price deductions, as shown in Figure 5.1. The lowest grade, E, only fetched a price of 2,000 VND per kg. ${ }^{2}$

The payoff depended on the subjects' choice of input quantity and a subsequent stochastic move of nature, which could take two states, good or bad, representing benign or malign production conditions. Production conditions affect quality. For instance, under malign conditions, output quality is lower than under benign conditions at the same level of input. Likewise, input quantity affects quality. The input, which subjects could purchase, has risk-reducing characteristics such that it dampens the negative effect of malign production conditions. This is a realistic assumption for many inputs used in dairy farming. For example, if adverse weather conditions affect farmers' own forage production, purchased fodder can help to reduce negative impacts on milk output. Purchased mineral fodder and vaccinations can help to reduce or avoid negative effects of animal disease. More broadly, the

\footnotetext{
${ }^{2}$ The prices for the quality grades resemble those that farmers actually received from the dairy processor at the time when the experiment was conducted (July 2009). All prices, costs, and revenues in the game are in VND. The official exchange rate in July 2009 was 1 USD = 17,522 VND.
} 
draw of nature represents a stochastic component affecting potential outcome, a feature inherent in most agricultural production processes. Since the dairy processing company wants to buy milk of high quality, it has an interest in farmers using sufficient quantities of input. It is important to note that the purchased input is sold by a separate, specialized company, not by the dairy processor, so that there is no conflict of interest. The experiment comprises three treatments, which are described in the following.

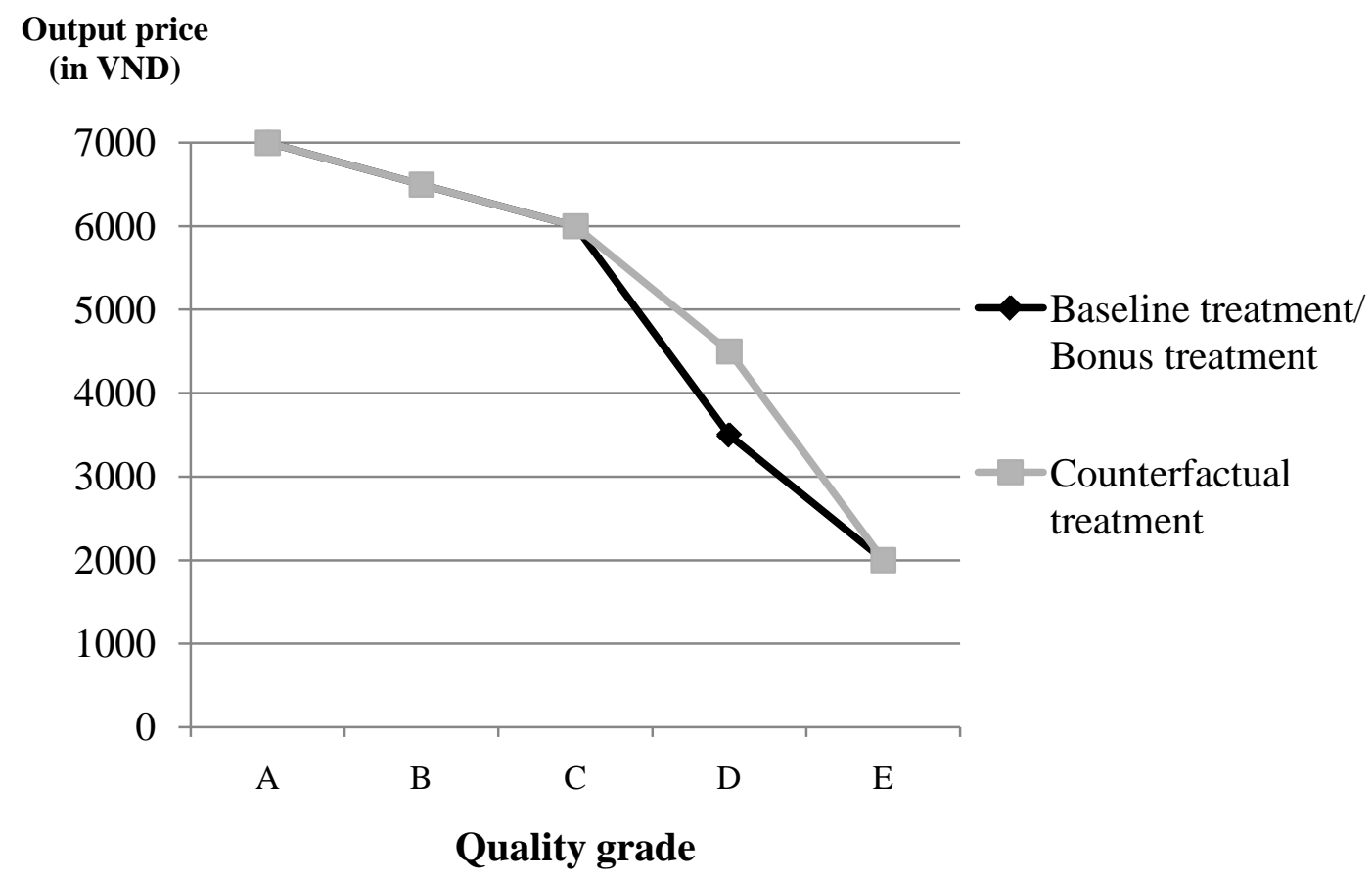

Figure 5.1: Pricing scheme by treatment

Source: Own data

Baseline treatment

The baseline treatment is called such, because it reflects the existing contract between dairy farmers and the processing company. The protocol comprised the following steps: 
1. At the beginning of the game $(t=0)$, before the first decisions were made, each subject received a random initial endowment $\vartheta_{i}$, with three possible levels $\vartheta_{i}=(25,000,30,000,35,000)$.

2. Subjects had to take a costly production decision, namely choose how many bags of input to purchase using the initial endowment $\vartheta_{i}$. The input, framed as a special type of mineral fodder, could be purchased in quantities of either zero, one, or two bags $q=(0,1,2)$ at unit price $p=10,000$. While the costs $\left(C_{v a r}=p q_{i}\right)$ associated with the choice of bags mimic variable costs of production, subjects also faced fixed costs $C_{f i x}=20,000$ for other types of fodder, veterinary service etc. Accordingly, the total cost of production was $T C_{i}=\left(p q_{i}\right)+C_{f i x}$. Variable costs are incurred at the beginning of each round; fixed costs are deducted only after the payoff has been realized.

3. Nature, which can take two possible states, $v=($ good, bad $)$, was randomly determined by a draw from an urn. The probability of nature taking the state good was $p=0.75$, while the probability of state bad was $(1-p)$.

4. Each subject $i$ realized a payoff (profit) $\Pi_{i}$, which depended on the individual input decision and the subsequent stochastic move of nature. $\Pi_{i}$ in the first round was determined according to

$$
\Pi_{i 1}=\vartheta_{i}+\left(T R_{i}-T C_{i}\right)=\vartheta_{i}+\left(\mathrm{TR}_{i}-\left(p q_{i}\right)-C_{f i x}\right)
$$

where $T R_{i}$ is the total revenue realized, which is a function of input choice $q$ and the state of nature $v, T R_{i}=\mathrm{f}(q, v)$. The possible profits for each input choice are depicted in Table 5.1 . 
As the game lasted $k=5$ rounds, steps 2,3 , and 4 were repeated five times leading to total payoff $\Pi_{i K}$ as follows:

$$
\Pi_{i K}=\vartheta_{i}+\sum_{i k}^{K}\left[\mathrm{TR}_{i k}-\left(p * q_{i k}\right)-C_{f i x_{k}}\right]
$$

The two gambles that are reflected by choice 1 and 2 stochastically dominate the gamble behind choice 0 (Table 5.1).

Table 5.1: Payoff distributions by treatment in '000 VND (quality grades in parentheses)

\begin{tabular}{|c|c|c|c|c|}
\hline & & \multicolumn{3}{|c|}{ Choice (number of bags of input) } \\
\hline \multicolumn{2}{|l|}{ Baseline treatment } & 0 & 1 & 2 \\
\hline \multirow{2}{*}{ State of nature } & $\operatorname{good}(p=0.75)$ & $15.00(\mathrm{D})$ & $35.00(\mathrm{~B})$ & $30.00(\mathrm{~A})$ \\
\hline & bad (1-p) & $0(\mathrm{E})$ & $5.00(\mathrm{D})$ & $20.00(\mathrm{C})$ \\
\hline \multirow{2}{*}{$\begin{array}{l}\text { Payoff distribution } \\
\text { moments }\end{array}$} & EV & 11.25 & 27.50 & 27.50 \\
\hline & SD & 6.50 & 12.99 & 4.33 \\
\hline \multirow{2}{*}{\multicolumn{2}{|c|}{ Counterfactual treatment }} & \multicolumn{3}{|c|}{ Choice (number of bags of input) } \\
\hline & & 0 & 1 & 2 \\
\hline \multirow{2}{*}{ State of nature } & $\operatorname{good}(p=0.75)$ & $25.00(\mathrm{D})$ & $35.00(\mathrm{~B})$ & $30.00(\mathrm{~A})$ \\
\hline & bad (1-p) & $0(\mathrm{E})$ & 15.00 (D) & $20.00(\mathrm{C})$ \\
\hline \multirow{2}{*}{$\begin{array}{l}\text { Payoff distribution } \\
\text { moments }\end{array}$} & EV & 18.75 & 30.00 & 27.5 \\
\hline & SD & 10.83 & 6.70 & 4.33 \\
\hline \multirow{2}{*}{\multicolumn{2}{|c|}{ Bonus treatment }} & \multicolumn{3}{|c|}{ Choice (number of bags of input) } \\
\hline & & 0 & 1 & 2 \\
\hline \multirow[t]{2}{*}{ State of nature } & $\operatorname{good}(p=0.75)$ & $15.00(\mathrm{D})$ & $35.00(\mathrm{~B})$ & $\begin{array}{c}30.00(+10.00 \\
\text { bonus after } 2 \\
\text { rounds) (A) }\end{array}$ \\
\hline & bad (1-p) & $0(\mathrm{E})$ & $5.00(\mathrm{D})$ & $20.00(\mathrm{C})$ \\
\hline \multirow{2}{*}{$\begin{array}{l}\text { Payoff distribution } \\
\text { moments }\end{array}$} & EV & 11.25 & 27.50 & 31.25 \\
\hline & SD & 6.50 & 12.99 & 7.77 \\
\hline
\end{tabular}

Notes: The unit prices per kg of milk are: A: 7,000; B: 6,500; C: 6,000; D: 3,500 in the baseline and bonus treatment and 4,500 in the counterfactual treatment; E: 2,000. The payoff per round is the profit from milk production, $\Pi=10 \mathrm{~kg}$ milk * unit price - fixed costs - variable costs. For example, if in the baseline treatment 1 bag of input is chosen and nature takes the state good, the quality would be B; the resulting profit is $\Pi=10 \mathrm{~kg}$ milk * 6,500 - 20,000 - 10,000 = 35,000.

Source: Own data 
This implies that the relatively small revenue due to poor output quality under choice 0 cannot be overcompensated by low initial input costs. In other words, some minimum use of input is necessary for profit maximization. Assuming that subjects maximize expected profit, the stochastic dominance effectively narrowed down the decision problem to a choice between two gambles ( 1 or 2 bags of input). The payoff distributions of choice 1 and 2 in the baseline treatment have the same expected value $(E V=27.5)$ but different standard deviations $(S D)$. For choice 1 , the SD is three times higher (12.99) than for choice 2 (4.33). We expect risk-averse subjects to purchase two bags of fodder, in order to avoid the risk of a low payoff when the state of nature is bad. Accordingly, the incentive effect underlying the pricing scheme stems from farmers’ potential preference for a lower SD of payoffs.

We now focus on the two additional treatments, in which the incentive structures were changed. Specifically, we altered the underlying pricing scheme that defines the relation between milk quality and price.

\section{Counterfactual treatment}

The counterfactual treatment was not designed as a ready-to-implement alternative to the pricing scheme currently used in the Vietnamese dairy industry. Rather, it aims at pinning down the effectiveness of the baseline incentives by showing what the outcome would look like under a modified pricing scheme. That is, we want to identify whether the financial penalty currently observed and reflected in the baseline treatment works effectively to increase input use and thus milk quality. As the company uses a country-wide standardized contract, there is no real-world 
variation in pricing schemes, so that this analysis would not be possible based on observational data.

The pricing scheme we chose for the counterfactual treatment resembles the one in the baseline, with the only difference that the price penalty for poor quality is less harsh. Specifically, the deduction in price for quality level D is smaller than in the baseline treatment (Figure 5.1). As a result, the relative moments of the payoff distributions change. While in the baseline, the EV was the same with 1 or 2 bags of input, in the counterfactual treatment, the EV is higher with 1 bag (Table 5.1). Hence, choosing 2 bags over 1 bag to keep the SD lower now requires giving up some EV. With this modification, any differences in input choice between the baseline and counterfactual treatments can be attributed to the stronger price penalty in the baseline scheme.

\section{Bonus treatment}

Next, we introduce an additional positive financial incentive. In the bonus treatment, a reward was paid for constantly high input use and resulting excellent output quality. The positive incentive (bonus payment) used here addresses the dissatisfaction with the existing pricing system, which farmers expressed during interviews carried out before the experiment. Farmers consider it imbalanced that there are harsh deductions for poor quality, but no rewards for excellent quality. In the bonus treatment, we used the baseline pricing scheme, but announced and paid an extra 10,000 VDN when A quality milk was delivered in two consecutive rounds. This changed the incentives fundamentally. While in the baseline scenario only a 
stick in the form of price deductions was employed, in the bonus treatment we added a carrot in the form of a conditional bonus payment.

The comparison of choices in the bonus and baseline treatments reveals if the bonus encourages subjects to choose higher input levels. We acknowledge that this comparison involves a change in more than one moment of the payoff distribution (Table 5.1), which makes it more difficult to identify the exact cause of observed behavioral change. An alternative would have been to raise the base price, but explorative discussions with company representatives revealed that this would not be a realistic option. On the other hand, a conditional bonus payment might be considered in reality. It should be noted that the level of the bonus chosen in the experiment is probably higher than what a company would be willing to pay. Given the limited number of subjects and treatments, we decided to calibrate the bonus at an upper boundary. If subjects are not driven into higher input use by a bonus payment of this size, smaller premiums would probably be even less effective.

\section{Additional details on design}

We close this subsection on experimental design by mentioning three additional points. First, a between-subject design was implemented, implying that each subject was exposed to one treatment only. Hence, the choice task was identical in each of the five rounds, ensuring that no treatment ordering effects confound the analysis (Harrison et al., 2005). Second, in designing the experiment we took into account that presentation of highly abstract and complex decision tasks may confuse subjects with limited numerical skills (Dave et al., 2010). The strong framing in terms of dairy farming and the comparably low complexity of the choice between 
gambles with identical probabilities leads to a simple task interface, which in our view is appropriate for the subject pool of Vietnamese dairy farmers.

Third, while Tanaka et al. (2010) conducted experiments in Vietnam that included a series of lotteries involving both losses and gains, we decided to use lotteries with gains (or zero payoff) only. This is comparable to Lybbert's (2006) experiment with Indian farmers and other studies where subjects are endowed at the beginning of the experiment and may lose only little money of this endowment in a given round. While this may not provide exactly the same incentive structure as in real-world situations, where farmers may incur losses after risky decisions, we note that it is the relative treatment effect that we are mainly interested in. This should be unaffected, because we compare treatments that all do not allow losses beyond the initial endowment.

\subsubsection{Sample selection and sample characteristics}

For the experiment we collaborated with Vietnam's largest dairy company. This company provided a complete list of 402 dairy farmers currently contracted in Long An and Tien Giang, two provinces south and west of HCMC. These provinces are representative dairy producing regions in Vietnam. More than two-thirds of Vietnam's total dairy population is held in the greater HCMC area (USDA, 2011). Milk production takes place on small farms. The average herd size in the sample is 7.8 heads, including cows, heifers, bulls, and calves. The animals are mostly crossbreeds of high-yielding Holstein-Friesian and local races. They are held in cowsheds year-round where they are fed with a ration of own-produced forage and purchased components such as concentrate and mineral fodder. The milk yield per cow (4,000 
to $4,500 \mathrm{~kg}$ per annum) is considerably lower than in developed countries, mostly due to poor herd management practices and suboptimal feeding.

Milk produced on the farms is not directly delivered to dairy plants in HCMC but is channelled through MCCs located in the vicinity of the farms. Roughly 100 farmers are grouped into an MCC, usually operated on commission by a private entrepreneur. Three of the four MCCs in the target region are geographically clustered, while the fourth is located around $50 \mathrm{~km}$ north-west of this cluster. We found significant differences in terms of some farm characteristics (e.g., herd size, milk quantity and quality) between producers delivering to different MCCs, which may be due to unobservable factors. For the three geographically clustered MCCs, farmers can choose freely where to deliver their milk. Anecdotal evidence suggests that this decision does not only depend on distance, but also on soft factors such as trust towards the manager of a particular MCC.

Employing factorial design, we generated treatment groups with the same average characteristics before implementing the experiment. We decided to pool farmers from both provinces. Out of the population of 402 farmers, we randomly sampled 205, who were then randomly assigned to one of the three treatments (baseline, counterfactual, and bonus). All sample farmers were visited in their homes for a comprehensive household survey using a structured questionnaire prior to the experiment (see below).

\subsubsection{Implementation and procedures}

We chose a large public gathering hall in the city of Long An as the venue for the experimental sessions. Long An is the capital city of Long An province and is located $50 \mathrm{~km}$ south of HCMC. All randomly selected farmers received a written 
invitation one week before the experiment was conducted. Farmers located close to the venue used their motorcycles to participate in the experiment, while a bus shuttle was installed for participants located further away. The public gathering hall was sufficiently large to allow wide spacing between participants. To ensure privacy during the decision-making process, the tables were equipped with voting boxes high enough to separate the subjects from each other.

The experiment comprised six sessions, which were conducted over the course of three days (one morning and one afternoon session on each day). Each farmer only participated in one of these sessions. Out of the six sessions, two followed the baseline, two the counterfactual, and two the bonus treatment protocol. In total, 185 of the 205 invited farmers showed up at the venue; hence, attrition was only 9 percent, suggesting high representativeness of the participants. Each session consisted of registration, instructions with trial rounds, five consecutive rounds of decision making, a short post-experiment survey, and payment. The average number of subjects per session was 31 .

At the beginning of the first round, farmers received an envelope containing the initial endowment in cash. This money was used to make the input purchase decision by inserting the cost for the chosen input quantity into an envelope, which was then collected by the experimenters. Subsequently, the state of nature was determined by drawing colored chips from an urn that contained three blue and one red chips, representing good and bad conditions, respectively. The probability of the good event was kept constant at $p=0.75$ and was known to all subjects. There were two different controlled sequences (one for each session) of events, which were repeated in each of the three treatments. In the first sequence, events were drawn in 
the following order: good-bad-good-good-bad. In the second sequence, the order was slightly different: good-good-bad-good-bad. While the sequence of draws was random to the subjects, it was not random to the experimenters in that it was determined prior to the experiment.

Controlling the sequence of events had two major advantages. First, with only five rounds per session, and the probability of a good event of $p=0.75$, purely stochastic on-site-draws of nature could have led to a situation where only very few or no bad events happened in a specific session. Through pre-drawn sequences, we could ensure a certain number of bad events and thus variation in the five-round spell. Second, we increased comparability between treatments. Given that the series of events was the same in each of the treatments, the treatment effect can be identified by comparing the outcomes without controlling for differences in realizations of states of nature. This would have been necessary if the realization of events was truly random and subjects maintained a heuristic understanding of probabilities (e.g., Hill and Viceisza, 2011).

After the state of nature was determined, the individual payoffs were computed based on the revenue resulting from farmers' choice and the cost of production. The resulting cash payoffs were placed in an envelope and redistributed to the individual farmer. Each round's payoff and the sum of payoffs from previous rounds could then be reinvested by purchasing input bags at the beginning of the following round. On average, farmers earned 129,800 VDN through participating in the experiment (varying from 90,000 to $150,000 \mathrm{VDN}$ ), which is equivalent to two daily wages for unskilled labor. 


\subsection{Empirical strategy and comparative analysis}

Given the random assignment of the treatment status, the average treatment effects are explored by (a) comparing mean input levels between the treatments and (b) regressing chosen input quantities on treatment dummies and other covariates, including socio-economic characteristics collected in the household survey.

\subsubsection{Survey data}

The household survey was conducted in April/May 2009, two months before the experiment was run. Demographic and socio-economic data were collected, including age, gender, education, and income-generating activities of household members, as well as asset ownership. Moreover, information on individual characteristics like altruism, trust, time preferences, and risk preferences was elicited. To capture altruism and trust levels, we included questions on whether interviewees gave money or would lend money to other farmers. Further, respondents had to rate the statement "the dairy company is trustworthy" on a Likert scale. ${ }^{3}$ Time preferences were captured as interest rates at which farmers were willing to postpone receiving a certain amount of money for three months. To elicit risk preferences, we included a Binswanger (1980) lottery in which interviewees had to choose between risky gambles. ${ }^{4}$

\footnotetext{
${ }^{3}$ Interviewees had to rate this statement on a four-point scale ("very much agree”, "agree”, "disagree", "very much disagree"; the option "I don't know" was also included). We collapsed the responses into a dummy taking the value 1 if farmers opted for "agree" or "very much agree", and 0 otherwise.

${ }^{4}$ Interviewees had to choose between five gambles with increasing SD of the payoff distributions (the probability of winning the higher prize was the same in each gamble). Accordingly, the variable takes the value 1 if farmers were risk averse and higher values if farmers were less risk averse (with 5 as upper bound).
} 


\subsubsection{Randomization}

The random assignment of experimental subjects led to treatment groups which were generally balanced with respect to most demographic and socioeconomic variables (Table 5.2). However, subjects in the bonus treatment tend to have less experience in dairy farming than their peers in the baseline and counterfactual groups. We also observe that subjects in the baseline group were more trustful but less wealthy than subjects in the counterfactual treatment. Despite these slight differences (which are random and non-systematic), the random assignment led to comparable treatment groups.

\subsubsection{Comparative analysis}

Mean values of the choice variable in the experiment (number of purchased input bags) are shown in Table 5.3 for the three treatments. The average choice over five rounds was 1.652 bags in the baseline treatment, while it was lower in the counterfactual treatment and higher in the bonus treatment. All differences are statistically significant. These comparisons imply two important but preliminary results in terms of the contract designs we are testing: First, the difference in input choice between the baseline and counterfactual scenario shows that the baseline pricing scheme, which mimics the financial incentives currently provided by the processing company, is effective in driving farmers into higher input use. Second, the average input quantity increases significantly when the penalty for low quality underlying the baseline specification is complemented with a bonus for consistent high quality. 
Table 5.2: Sample means of selected characteristics by treatment

\begin{tabular}{|c|c|c|c|c|c|c|}
\hline \multirow[b]{2}{*}{ Variables } & \multicolumn{3}{|c|}{ Treatment } & \multicolumn{3}{|c|}{ Mean differences } \\
\hline & $\begin{array}{l}\text { Baseline } \\
\text { (T1) }\end{array}$ & $\begin{array}{l}\text { Counterf. } \\
\text { (T2) }\end{array}$ & $\begin{array}{l}\text { Bonus } \\
\text { (T3) }\end{array}$ & $\mathrm{T} 1-\mathrm{T} 2$ & T1-T3 & T2-T3 \\
\hline \multicolumn{7}{|l|}{ Demographic variables } \\
\hline Age (years) & $\begin{array}{c}42.83 \\
{[9.466]}\end{array}$ & $\begin{array}{c}42.68 \\
{[12.04]}\end{array}$ & $\begin{array}{c}45.30 \\
{[11.88]}\end{array}$ & $\begin{array}{c}0.150 \\
{[1.977]}\end{array}$ & $\begin{array}{c}-2.464 \\
{[1.937]}\end{array}$ & $\begin{array}{l}-2.614 \\
{[2.149]}\end{array}$ \\
\hline Gender (1=female) & $\begin{array}{c}0.197 \\
{[0.401]}\end{array}$ & $\begin{array}{c}0.200 \\
{[0.403]}\end{array}$ & $\begin{array}{c}0.109 \\
{[0.315]}\end{array}$ & $\begin{array}{c}-0.003 \\
{[0.073]}\end{array}$ & $\begin{array}{c}0.087 \\
{[0.064]}\end{array}$ & $\begin{array}{c}0.091 \\
{[0.065]}\end{array}$ \\
\hline Education (years of schooling) & $\begin{array}{c}8.800 \\
{[4.372]}\end{array}$ & $\begin{array}{c}8.650 \\
{[2.748]}\end{array}$ & $\begin{array}{c}8.094 \\
{[3.079]}\end{array}$ & $\begin{array}{c}0.150 \\
{[0.667]}\end{array}$ & $\begin{array}{c}0.706 \\
{[0.676]}\end{array}$ & $\begin{array}{c}0.556 \\
{[0.525]}\end{array}$ \\
\hline \multicolumn{7}{|c|}{ Economic and dairy production variables } \\
\hline Total assets (100 USD) & $\begin{array}{c}26.264 \\
{[0.861]}\end{array}$ & $\begin{array}{l}28.110 \\
{[1.025]}\end{array}$ & $\begin{array}{l}27.553 \\
{[1.107]}\end{array}$ & $\begin{array}{l}-1.847^{*} \\
{[1.339]}\end{array}$ & $\begin{array}{l}-1.290 \\
{[1.415]}\end{array}$ & $\begin{array}{c}0.557 \\
{[1.514]}\end{array}$ \\
\hline Total HH income ('000 VND) & $\begin{array}{c}84.399 \\
{[53.965]}\end{array}$ & $\begin{array}{c}86.455 \\
{[55.144]}\end{array}$ & $\begin{array}{c}78.330 \\
{[70.493]}\end{array}$ & $\begin{array}{l}-2.056 \\
{[9.961]}\end{array}$ & $\begin{array}{c}6.069 \\
{[11.360]}\end{array}$ & $\begin{array}{c}8.124 \\
{[11.450]}\end{array}$ \\
\hline Dairy income ('000 VND) & $\begin{array}{c}58.050 \\
{[51.256]}\end{array}$ & $\begin{array}{c}62.738 \\
{[52.439]}\end{array}$ & $\begin{array}{c}46.812 \\
{[47.779]}\end{array}$ & $\begin{array}{l}-4.689 \\
{[9.588]}\end{array}$ & $\begin{array}{c}11.238 \\
{[89.679]}\end{array}$ & $\begin{array}{l}15.926 \\
{[9.187]}\end{array}$ \\
\hline Experience in dairy farming (years) & $\begin{array}{c}4.850 \\
{[3.434]}\end{array}$ & $\begin{array}{c}4.483 \\
{[2.514]}\end{array}$ & $\begin{array}{c}3.766 \\
{[2.395]}\end{array}$ & $\begin{array}{c}0.367 \\
{[0.549]}\end{array}$ & $\begin{array}{l}1.084^{*} \\
{[0.529]}\end{array}$ & $\begin{array}{c}0.718 \\
{[0.441]}\end{array}$ \\
\hline Dairy herd size (heads) & $\begin{array}{c}8.417 \\
{[5.328]}\end{array}$ & $\begin{array}{c}7.950 \\
{[4.300]}\end{array}$ & $\begin{array}{c}7.016 \\
{[4.463]}\end{array}$ & $\begin{array}{c}0.467 \\
{[0.884]}\end{array}$ & $\begin{array}{c}1.401 \\
{[0.881]}\end{array}$ & $\begin{array}{c}0.934 \\
{[0.788]}\end{array}$ \\
\hline Concentrate use (kg/cow*day) & $\begin{array}{c}7.950 \\
{[1.826]}\end{array}$ & $\begin{array}{c}7.475^{\mathrm{a}} \\
{[1.437]}\end{array}$ & $\begin{array}{c}7.802 \\
{[2.153]}\end{array}$ & $\begin{array}{l}0.475^{* *} \\
{[0.302]}\end{array}$ & $\begin{array}{c}0.148 \\
{[0.363]}\end{array}$ & $\begin{array}{c}-0.327 \\
{[0.334]}\end{array}$ \\
\hline \multicolumn{7}{|l|}{ Affiliation to milk collection center } \\
\hline Delivering milk to MCC 1 & $\begin{array}{c}0.311 \\
{[0.467]}\end{array}$ & $\begin{array}{c}0.233 \\
{[0.427]}\end{array}$ & $\begin{array}{c}0.266 \\
{[0.445]}\end{array}$ & $\begin{array}{c}0.078 \\
{[0.081]}\end{array}$ & $\begin{array}{c}0.046 \\
{[0.082]}\end{array}$ & $\begin{array}{c}-0.032 \\
{[0.078]}\end{array}$ \\
\hline Delivering milk to MCC 2 & $\begin{array}{c}0.279 \\
{[0.452]}\end{array}$ & $\begin{array}{c}0.233 \\
{[0.427]}\end{array}$ & $\begin{array}{c}0.344 \\
{[0.479]}\end{array}$ & $\begin{array}{c}0.045 \\
{[0.080]}\end{array}$ & $\begin{array}{c}-0.065 \\
{[0.083]}\end{array}$ & $\begin{array}{c}-0.110 \\
{[0.082]}\end{array}$ \\
\hline Delivering milk to MCC 3 & $\begin{array}{c}0.197 \\
{[0.401]}\end{array}$ & $\begin{array}{c}0.267 \\
{[0.446]}\end{array}$ & $\begin{array}{c}0.219 \\
{[0.417]}\end{array}$ & $\begin{array}{l}-0.070 \\
{[0.077]}\end{array}$ & $\begin{array}{c}-0.022 \\
{[0.073]}\end{array}$ & $\begin{array}{c}0.048 \\
{[0.078]}\end{array}$ \\
\hline Delivering milk to MCC 4 & $\begin{array}{c}0.197 \\
{[0.401]}\end{array}$ & $\begin{array}{c}0.267 \\
{[0.446]}\end{array}$ & $\begin{array}{c}0.172 \\
{[0.380]}\end{array}$ & $\begin{array}{l}-0.070 \\
{[0.077]}\end{array}$ & $\begin{array}{c}0.025 \\
{[0.070]}\end{array}$ & $\begin{array}{c}0.095 \\
{[0.074]}\end{array}$ \\
\hline \multicolumn{7}{|l|}{ Preferences } \\
\hline $\begin{array}{l}\text { Risk preference (1-5 with } 1 \text { being most } \\
\text { risk-averse) }\end{array}$ & 1.850 & 1.650 & 1.906 & 0.200 & -0.056 & -0.256 \\
\hline Patient (discount rate <=3.5\%; $1=y$ ) & $\begin{array}{c}{[1.191]} \\
0.383 \\
{[0.490]}\end{array}$ & $\begin{array}{c}{[1.087]} \\
0.267 \\
{[0.446]}\end{array}$ & $\begin{array}{c}{[1.231]} \\
0.359 \\
{[0.484]}\end{array}$ & $\begin{array}{c}{[0.208]} \\
0.117 \\
{[0.086]}\end{array}$ & $\begin{array}{c}{[0.218]} \\
0.024 \\
{[0.088]}\end{array}$ & $\begin{array}{c}{[0.209]} \\
-0.093 \\
{[0.084]}\end{array}$ \\
\hline Dairy company is trustworthy $(1=y)$ & $\begin{array}{c}0.590 \\
{[0.496]}\end{array}$ & $\begin{array}{c}0.533 \\
{[0.503]}\end{array}$ & $\begin{array}{c}0.563 \\
{[0.500]}\end{array}$ & $\begin{array}{c}0.057 \\
{[0.091]}\end{array}$ & $\begin{array}{c}-0.029 \\
{[0.090]}\end{array}$ & $\begin{array}{c}-0.028 \\
{[0.089]}\end{array}$ \\
\hline \multirow{2}{*}{$\begin{array}{l}\text { Trust proxy (money lent to farmers; } \\
1=y \text { ) }\end{array}$} & 1.400 & 1.300 & 1.170 & 0.100 & $0.228 * * *$ & $0.128^{* * *}$ \\
\hline & [0.068] & {$[0.060]$} & {$[0.048]$} & {$[0.091]$} & {$[0.082]$} & {$[0.076]$} \\
\hline Altruism (money given to farmer; $1=y$ ) & $\begin{array}{c}1.150 \\
{[0.360]}\end{array}$ & $\begin{array}{c}1.217 \\
{[0.415]}\end{array}$ & $\begin{array}{c}1.109 \\
{[0.315]}\end{array}$ & $\begin{array}{l}-0.0667 \\
{[0.071]}\end{array}$ & $\begin{array}{l}0.0406 \\
{[0.061]}\end{array}$ & $\begin{array}{c}0.107 \\
{[0.066]}\end{array}$ \\
\hline Observations & 61 & 60 & 64 & & & \\
\hline
\end{tabular}

Notes: Standard deviations in brackets

$* * * \mathrm{p}<0.01, * * \mathrm{p}<0.05, * \mathrm{p}<0.10$

${ }^{a}$ One outlier was omitted for this variable $(n=59)$

Source: Own data 
Further, the results provide insights into the risk preferences of our subjects. The payoffs in the baseline treatment were calibrated such that risk-neutral subjects would be indifferent between choosing 1 or 2 bags of input (see Table 5.1 and subsection 5.3.1). Consequently, the mean choice should asymptotically converge to 1.5, given enough observations. However, the observed mean choice in the baseline treatment is significantly larger than 1.5 (at 1 percent error rate), suggesting that farmers were not indifferent but preferred to choose 2 bags (which represents the gamble with lower SD of the payoff distribution).

Table 5.3: Mean input choice by treatment

\begin{tabular}{|c|c|c|c|c|c|c|}
\hline & \multicolumn{3}{|c|}{ Treatment } & \multicolumn{3}{|c|}{ Mean differences } \\
\hline & $\begin{array}{l}\text { Baseline } \\
\text { (T1) }\end{array}$ & $\begin{array}{l}\text { Counterfactual } \\
\text { (T2) }\end{array}$ & $\begin{array}{l}\text { Bonus } \\
\text { (T3) }\end{array}$ & $\mathrm{T} 1-\mathrm{T} 2$ & T1-T3 & T2-T3 \\
\hline \multirow[t]{2}{*}{ Number of bags } & 1.652 & 1.410 & 1.769 & $0.242 * * *$ & $-0.116 * *$ & $-0.359 * * *$ \\
\hline & [0.565] & [0.591] & {$[0.471]$} & [0.047] & {$[0.042]$} & [0.043] \\
\hline Observ. (NK) & 305 & 300 & 320 & & & \\
\hline Rounds (K) & 5 & 5 & 5 & & & \\
\hline $\begin{array}{l}\text { Number of } \\
\text { individuals }(\mathrm{N})\end{array}$ & 61 & 60 & 64 & & & \\
\hline
\end{tabular}

The results of the counterfactual treatment underpin these findings. In this treatment, risk-neutral subjects would be expected to prefer buying 1 bag to realize the highest EV of the payoff distribution. However, we observe a significantly larger average choice (1.41). Subjects chose more bags, giving up some EV for a lower SD, pointing to a considerable level of risk aversion.

These descriptive results are preliminary due to potentially confounding factors such as the statistically significant differences in characteristics between 
treatment groups or round and session effects. Therefore, we employ a regression framework, controlling for such confounding factors. Moreover, with suitable regression model specifications we can investigate potential mechanisms driving the observed input decisions.

\subsubsection{Regression analysis}

For the regression analysis we use input choice as dependent variable. By design this is restricted to integers between 0 and 2 . To account for the left and right censoring of the dependent variable, we employ a Tobit model with the following specification:

$$
y=\propto+\beta \boldsymbol{T}+\gamma \boldsymbol{X}+\delta \boldsymbol{X} \boldsymbol{T}+\vartheta \boldsymbol{Z}+\sigma \mathbf{Z T}+\varepsilon,
$$

where the dependent variable $y$ is the number of purchased input bags in a given round, $\boldsymbol{T}$ is a vector of treatment dummies, and $\boldsymbol{X}$ is a vector of control variables. $\boldsymbol{X}$ includes experiment-specific variables such as round and session dummies, as well as household and individual characteristics for which we found differences in mean values between treatment groups.

In subsequent specifications, we introduce a vector $\mathbf{Z}$, which comprises additional socio-demographic variables. $\boldsymbol{Z}$ can also help to explain some of the mechanisms that may drive farmers' input purchase decisions. We expect risk preferences and wealth to play a role. Selected variables of $\boldsymbol{X}$ and $\boldsymbol{Z}$ are also interacted with $\boldsymbol{T}$. The interaction terms allow us to analyze heterogeneous treatment effects. $\varepsilon$ is the error term.

To exploit the panel structure of the experimental data, with several rounds of decisions, we use a random effects longitudinal Tobit model. This takes into account 
that each subject was only exposed to one treatment, that is, the treatment effects can only be identified across groups, not across time (experimental rounds).

\subsection{Regression results}

The regression results are depicted in Tables 5.4 and 5.5. ${ }^{5}$ Model (I) in Table 5.5 is a simple specification, which only includes the treatment dummies for the counterfactual and bonus treatments (the baseline treatment is the reference). The treatment effect is negative (positive) and significant for the counterfactual (bonus) dummy. This confirms the results from the comparative analysis, namely that the harsh price penalty for low quality milk in the baseline increases input use, and that this effect can be further strengthened through an additional bonus.

In model (II) we add a set of binary variables to control for session (morning or afternoon) and round-specific factors. The subjects' ability to understand the rules of the game may also play a role. In the short post-experimental survey, farmers had to answer a simple question of understanding. Based on this, we constructed the dummy 'misunderstanding of instructions', which takes the value 1 if this question was not correctly answered. Further, we control for the previously discussed differences in farm and household characteristics between treatment groups.

The results for model (II) in Table 5.4 show that the treatment effects remain robust; for the bonus treatment, the effect even increases in magnitude. The session effect is not significant, although the interaction terms suggest that the impact of the bonus was lower in afternoon sessions. The coefficients of the dummies for later

\footnotetext{
${ }^{5}$ The number of observations varies slightly between different model specifications. The reason is that in some cases, the person participating in the experiment was a household member other than the respondent in the preceding survey (e.g., the survey respondent was sick at the time of the experiment). For regressions with individual-specific covariates from the survey, these cases had to be dropped.
} 
rounds are positive and significant, implying that farmers' willingness to invest in inputs increased over time. This may be due to learning effects. End-of-game effects may also play a role, although farmers did not know the exact number of rounds to play before the game actually ended. The results further show that subjects who had difficulties to understand the rules of the game purchased significantly fewer bags of input, which is plausible.

Table 5.4: Estimation results (random effects longitudinal Tobit model)

\begin{tabular}{|c|c|c|c|c|c|c|}
\hline & \multicolumn{2}{|l|}{ (I) } & \multicolumn{2}{|c|}{ (II) } & \multicolumn{2}{|c|}{ (III) } \\
\hline & Coefficient & $\mathrm{SE}$ & Coefficient & SE & Coefficient & SE \\
\hline \multicolumn{7}{|l|}{ Treatment variables } \\
\hline Counterfactual treatment T2 $(1=y)$ & $-0.719 * * *$ & 0.140 & $-0.652 * * *$ & 0.190 & $-0.609 * * *$ & 0.217 \\
\hline Bonus treatment T3 (1=y) & $0.438 * * *$ & 0.149 & $1.432 * * *$ & 0.243 & $1.502 * * *$ & 0.285 \\
\hline \multicolumn{7}{|l|}{ Variables $X$} \\
\hline Session dummy (1=afternoon) & & & 0.325 & 0.205 & 0.204 & 0.227 \\
\hline Session $* \mathrm{~T} 2$ & & & 0.193 & 0.278 & 0.324 & 0.317 \\
\hline Session * T3 & & & $-1.108 * * *$ & 0.312 & $-0.615 *$ & 0.372 \\
\hline Round 2 dummy (1=y) & & & -0.005 & 0.173 & -0.030 & 0.193 \\
\hline Round 3 & & & 0.216 & 0.176 & 0.202 & 0.197 \\
\hline Round 4 & & & $0.392 * *$ & 0.179 & $0.418 * *$ & 0.202 \\
\hline Round 5 & & & $0.454 * *$ & 0.180 & $0.519 * *$ & 0.203 \\
\hline Misunderstanding of instructions $(1=\mathrm{n})$ & & & $-0.809 * * *$ & 0.165 & $-0.818^{* * *}$ & 0.198 \\
\hline Dairy farming experience (yrs) & & & $0.046^{* *}$ & 0.023 & $0.065^{* *}$ & 0.026 \\
\hline Concentrate use (kg/cow*day) & & & $0.115^{* * *}$ & 0.036 & $0.140 * * *$ & 0.038 \\
\hline Trust (money lent to farmer; $1=y$ ) & & & 0.081 & 0.134 & $-0.297^{*}$ & 0.170 \\
\hline Total assets (in 100 USD) & & & -0.006 & 0.004 & $-0.011^{* *}$ & 0.004 \\
\hline \multicolumn{7}{|l|}{ Variables Z } \\
\hline Age (yrs) & & & & & $-0.025^{* * *}$ & 0.006 \\
\hline Gender (1=female) & & & & & $-0.336 *$ & 0.199 \\
\hline Education (yrs) & & & & & -0.007 & 0.021 \\
\hline MCC 1 dummy (1=y) & & & & & $-0.377 * *$ & 0.179 \\
\hline MCC 3 dummy (1=y) & & & & & $0.458 * *$ & 0.213 \\
\hline MCC 4 dummy (1=y) & & & & & 0.131 & 0.220 \\
\hline Sigma u & 0.131 & 0.082 & 0.000 & 0.056 & 0.000 & 0.063 \\
\hline Sigma e & $1.451^{* * *}$ & 0.074 & $1.377^{* * *}$ & 0.071 & $1.359 * * *$ & 0.080 \\
\hline Constant & $2.614 * * *$ & 0.131 & $1.240 * * *$ & 0.336 & $2.386 * * *$ & 0.470 \\
\hline Observations & 925 & & $910^{\mathrm{a}}$ & & $735^{\mathrm{a}}$ & \\
\hline Number of rounds & 5 & & 5 & & 5 & \\
\hline
\end{tabular}

Notes: The dependent variable in all models is the number of input bags chosen in a given round (0-2).

*** $\mathrm{p}<0.01, * * \mathrm{p}<0.05, * \mathrm{p}<0.10$

${ }^{a}$ Observations for which experimental subject and respondent in the household survey are not identical were excluded.

Source: Own data 
The positive coefficient of concentrate use shows that farmers who purchase more fodder in reality also purchased a larger number of bags in the experiment. This is a welcome finding, as it confirms that the experimental framing was realistic. Finally, subjects with more experience in dairy farming tend to purchase more input bags.

In model (III) we include additional variables that capture household demographic factors and possible MCC effects. Again, the treatment effects remain robust. Being female and being older seem to have negative impacts on input purchases. The risk literature suggests that women and older individuals often tend to be more risk averse (Eckel and Grossman 2008). Hence, our results may surprise, given that the input in the experiment is risk reducing. One possible explanation is that the mineral fodder is regarded as a new and risky technology by some. Two of the MCC dummies have significant effects, which we attribute to unobserved factors (see subsection 5.3.2).

Role of risk preferences

The comparative analysis showed that some subjects preferred gambles with lower SD, even giving up higher EV of an alternative gamble. This suggests that farmers are risk averse. To explore further whether risk aversion explains the observed behavior, we specify model (IV) where we include the risk proxy variable from the household survey, which we also interact with the treatment dummies. The estimation results are shown in Table 5.5. Risk preferences do not seem to affect input choice significantly. One possible explanation may be that the data variation for risk preferences is relatively low. In the survey, 60 percent of the respondents opted for the least risky gamble, only 5 percent opted for the riskiest alternative. 
Table 5.5: Additional estimation results (random effects longitudinal Tobit model)

\begin{tabular}{|c|c|c|c|c|c|c|}
\hline & \multicolumn{2}{|c|}{$(\mathrm{IV})$} & \multicolumn{2}{|c|}{$(\mathrm{V})$} & \multicolumn{2}{|c|}{$(\mathrm{VI})$} \\
\hline & Coefficient & SE & Coefficient & SE & Coefficient & SE \\
\hline \multicolumn{7}{|l|}{ Treatment variables } \\
\hline Counterfactual treatment T2 $(1=y)$ & $-0.689 * *$ & 0.326 & -0.511 & 0.518 & -0.594 & 0.585 \\
\hline Bonus treatment T3 (1=y) & $1.731 * * *$ & 0.404 & $2.566 * * *$ & 0.660 & $2.890 * * *$ & 0.744 \\
\hline \multicolumn{7}{|l|}{ Variables $X$} \\
\hline Session dummy (1=afternoon) & 0.201 & 0.227 & 0.229 & 0.225 & 0.228 & 0.225 \\
\hline Session * T2 & 0.316 & 0.317 & 0.308 & 0.314 & 0.299 & 0.314 \\
\hline Session * T3 & -0.580 & 0.372 & $-0.628 *$ & 0.368 & -0.591 & 0.369 \\
\hline Round 2 dummy (1=y) & -0.029 & 0.193 & -0.169 & 0.199 & -0.169 & 0.199 \\
\hline Round 3 & 0.202 & 0.196 & 0.244 & 0.196 & 0.244 & 0.196 \\
\hline Round 4 & $0.420 * *$ & 0.202 & $0.475^{* *}$ & 0.202 & $0.477 * *$ & 0.202 \\
\hline Round 5 & $0.519 * *$ & 0.203 & $0.380 *$ & 0.209 & $0.381 *$ & 0.208 \\
\hline Misunderstanding of instructions $(1=n)$ & $-0.812^{* * *}$ & 0.199 & $-0.790 * * *$ & 0.196 & $-0.784 * * *$ & 0.197 \\
\hline Dairy farming experience (yrs) & $0.064^{* *}$ & 0.026 & $0.061^{* *}$ & 0.026 & $0.061^{* *}$ & 0.026 \\
\hline Concentrate use (kg/cow*day) & $0.142^{* * *}$ & 0.038 & $0.135 * * *$ & 0.038 & $0.137 * * *$ & 0.038 \\
\hline Trust (money lent to farmer; $1=y$ ) & $-0.294^{*}$ & 0.170 & $-0.305^{*}$ & 0.168 & $-0.300 *$ & 0.169 \\
\hline Total assets (in 100 USD) & $-0.010 * *$ & 0.005 & $-0.011 * *$ & 0.004 & $-0.010 * *$ & 0.005 \\
\hline \multicolumn{7}{|l|}{ Variables Z } \\
\hline Age (yrs) & $-0.026 * * *$ & 0.006 & $-0.024 * * *$ & 0.006 & $-0.024 * * *$ & 0.006 \\
\hline Gender ( $1=$ female) & $-0.351 *$ & 0.199 & -0.321 & 0.198 & $-0.338 *$ & 0.198 \\
\hline Education (yrs) & -0.007 & 0.021 & -0.006 & 0.021 & -0.006 & 0.021 \\
\hline MCC 1 dummy (1=y) & $-0.392 * *$ & 0.180 & $-0.382 * *$ & 0.177 & $-0.398 * *$ & 0.178 \\
\hline MCC 3 dummy (1=y) & $0.437 * *$ & 0.213 & $0.450 * *$ & 0.211 & $0.428 * *$ & 0.211 \\
\hline MCC 4 dummy (1=y) & 0.120 & 0.223 & 0.135 & 0.219 & 0.119 & 0.222 \\
\hline \multicolumn{7}{|l|}{ Mechanism I: Risk preferences } \\
\hline Risk proxy (1=risk averse; 5=risk loving) & 0.010 & 0.103 & & & 0.027 & 0.103 \\
\hline Risk proxy * $\mathrm{T} 2$ & 0.056 & 0.147 & & & 0.050 & 0.146 \\
\hline Risk proxy * T3 & -0.144 & 0.168 & & & -0.169 & 0.167 \\
\hline \multicolumn{7}{|l|}{ Mechanism II: Wealth } \\
\hline Lagged profit (in ‘000 VND) & & & $0.032 * *$ & 0.013 & $0.032 * *$ & 0.013 \\
\hline Lagged profit $* \mathrm{~T} 2$ & & & -0.005 & 0.018 & -0.005 & 0.018 \\
\hline Lagged profit * T3 & & & $-0.042 *$ & 0.023 & $-0.044^{*}$ & 0.023 \\
\hline Sigma u & 0.000 & 0.063 & 0.000 & 0.063 & 0.000 & 0.062 \\
\hline Sigma e & $1.357 * * *$ & 0.079 & $1.342 * * *$ & 0.079 & $1.340 * * *$ & 0.078 \\
\hline Constant & $2.360 * * *$ & 0.498 & $1.543 * * *$ & 0.564 & $1.486^{* *}$ & 0.594 \\
\hline Observations & $735^{\mathrm{a}}$ & & $735^{\mathrm{a}}$ & & $735^{\mathrm{a}}$ & \\
\hline Number of rounds & 5 & & 5 & & 5 & \\
\hline
\end{tabular}

Notes: The dependent variable in all models is the number of input bags chosen in a given round $(0-2)$

$* * * \mathrm{p}<0.01,{ }^{* *} \mathrm{p}<0.05, * \mathrm{p}<0.10$

${ }^{a}$ Observations for which experimental subject and respondent in the household survey are not identical were excluded

Source: Own data

\section{Role of wealth}

Wealth levels may also explain farmers' input choices. We differentiate between wealth levels external and internal to the experiment. Wealth external to the experiment is captured through the total value of assets owned. This is based on the household survey and was already included in previous model specifications. Wealth 
internal to the experiment is captured by lagged profit, that is, profit realized in the previous round. ${ }^{6}$ Both measures of wealth are not correlated and hence are included simultaneously in models (V) and (VI). Table 5.5 shows that assets have a small negative effect on input choice, while lagged profit has a positive and significant effect. Subjects who realized higher profits in the previous round tend to invest more. This is probably related to liquidity considerations: subjects purchase more inputs when they are less financially constrained. Interacting lagged profit with the treatment dummies shows that the positive effect of internal wealth disappears in the bonus treatment.

\subsection{Conclusion}

Modern and more integrated supply chains for high-value agricultural products are gaining in importance in many developing countries. These supply chains often involve contractual arrangements between agribusiness companies and farmers. Whether smallholder farmers can successfully participate and benefit from contract schemes depends on many factors. One important question is how well they meet specific quality requirements. If smallholders have a tendency to produce lower quality, companies will search for alternatives, such as sourcing raw material from larger farms or engaging in primary production themselves. This could entail further marginalization of smallholders. Farmers' behavior and performance depend on abilities and incentive structures, which can be influenced through contracts. Yet, relatively little is known about suitable contractual designs in a smallholder context.

We conducted a framed field experiment with Vietnamese dairy farmers to better understand the relationships between contractual pricing schemes, input use,

\footnotetext{
${ }^{6}$ For the first round in each experimental session, we use the stochastic initial endowment.
} 
and output quality. The experimental data were complemented with socio-economic data from a household survey. The production contract, which is currently used in Vietnam, builds on strong price penalties for lower quality milk. Our results confirm that this is an effective instrument to incentivize higher input use among farmers. Providing a bonus payment for consistent high quality further increases input use. But obviously, a bonus payment would entail additional costs for the buying company. The amount of bonus in the experiment was effective but relatively large. A somewhat lower bonus or some form of targeting may also work potentially. In the end, it remains an empirical question whether the marginal benefits for the company can over-compensate the marginal costs of the bonus payment under real-world conditions. This depends on the supply response of farmers and the value that the company attributes to increases in quality, which is hard to analyze in framed field experiments.

A contract design that relies only on price penalties as an incentive to produce high quality is typical for a monopsonistic situation. In Vietnam, dairy farmers hardly have options to sell their milk outside the contract. They also incur relationship-specific investments, so that their bargaining power is limited. This may be a favorable situation for the buying company in the short run. But there could be a downside from a more dynamic perspective. If farmers are threatened into high input use by harsh price penalties, their cost of production may increase. In agricultural markets where margins for sellers are low, heavily investing in variable risk-reducing inputs may potentially strain the capacity to invest in longer term upgrading of the enterprise. This is especially true among smallholder farmers, who are often liquidity constrained. Thus, through harsh negative incentives, the contracting company might 
strangulate future growth of its supplier base. This may result in stagnating productivity among contract farms, obstructing potentials for reduced transaction costs in the future. 


\section{Impact of third-party enforcement of contracts}

\subsection{Introduction}

Asymmetry of information is a fundamental problem in economics. When information is not freely available but instead costly to obtain for one part in a transaction, markets eventually may break down. Since Akerlof's (1970) seminal paper on the market for used automobiles, economics of information has received considerable attention. Models of moral hazard, adverse selection and signaling have been applied to study various domains of economic interaction, as diverse as labor markets, markets for insurances, credit, real estate and even art (Ross, 1973; Spence, 1973; Rothschild and Stiglitz, 1976; Stiglitz and Weiss, 1981; Grossmann, 1981; Throsby 1994).

However, information asymmetry regarding product attributes does not only play a role in transactions with metaphorical fruit such as lemons but also in markets for actual agricultural produce, for example if special technology is required to assess non-tangible quality attributes such as nutrient content or bacterial contamination and costs to gather this information are prohibitively high for the selling farmer. Hence, in many agricultural markets in which supply chain relations are facilitated through production contracts, the principal (e.g. buying processor or wholesaler) has more information about output quality attributes than the agent (selling farmer). This implies that agricultural production contracts remain incomplete (Gow and Swinnen, 1998). The information asymmetry between seller and buyer regarding product 
quality gives scope for opportunistic behavior on the side of the buyer who can accrue information rents from reporting lower than actual quality levels, thus downgrading the price paid to the seller. However, rational sellers forming the belief that the buyer cheats would factor in the buyer's opportunistic behavior, lowering their expectations about the product price they receive. Thus, weak contract enforcement can induce sellers to underinvest (Gow et al., 2000; Vukina and Leegomonchai, 2006; Cungu et al., 2008). Underinvestment, i.e. suboptimal shortterm input use or downsizing of investment in long-term productive assets, leads to lower output, negatively affecting not only the agent's outcome but also increasing the principal's per-unit transaction costs from procurement.

To overcome information asymmetry in the supply chain, more transparency, e.g. through third-party quality measurement and verification in yet incomplete contracts is one solution (Balbach, 1998; Sykuta and Cook, 2001; Young and Hobbs, 2002). In a laboratory experiment Wu and Roe (2007) have shown that third-party contract enforcement can be one way to successfully mitigate underinvestment and enhance social efficiency. But as the laboratory systematically differs from natural environments, the external validity of these type of studies may be limited (Levitt and List, 2007). Hence, over the past decade field experiments (or randomized control trials) in which subjects take decisions in their natural environment have become extensively used. This approach has enabled economists to convincingly isolate and measure the treatment effect of interventions in the field of social welfare, health care and education without compromising real world complexity (Skoufias, 2001; Miguel and Kremer, 2004; Kremer et al., 2005). Only recently, randomized 
control trials have been carried out in the field of agriculture (Duflo et al., 2008; 2011; Ashraf et al., 2009).

For the first time applying this novel approach to the evolving field of the study of agricultural contracts, we carried out a field experiment using the example of the fast growing Vietnamese dairy industry in which third-party enforcement is yet missing. The dairy sector is characterized by a great number of small-scale dairy farmers who are contracted by a large milk processing company, and hence is an excellent example for emerging markets for high-value agricultural products in developing countries (Reardon et al. 2009; Mergenthaler et al. 2009). In this field experiment the contract of a randomly chosen subsample of farmers, the treatment group, is altered such that it becomes third-party-enforced; previously unobservable quality attributes are now measured and verified by an independent and certified laboratory; control group farmers continue to produce under the initial contract. By comparing the outcomes of both groups we address the following research questions: (i) Does contract enforcement through third-party verification of quality attributes lead to increased production intensity and higher milk output, and (ii) does this intervention increase the welfare of the small-scale milk producers?

In the framework of this field experiment we closely collaborate with a private-sector dairy company which enables us to access weekly farm-level output data. This information is complemented with data from own extensive household surveys. We find that our intervention leads to higher input use and increased dairy output. There is also a positive treatment effect with respect to household expenditures for a specific subgroup of our sample. We are able to attribute observed differences in output to a behavioral change of farmers rather than alterations in the 
reporting strategy of the buying company. This also implies that in this specific case we observed a situation in which the buying company did not behave opportunistically, but failed to signal its fair type to the selling farmers. Hence, thirdparty enforcement in agricultural markets with incomplete contracts can lead to a Pareto improvement as both smallholders and processors or wholesalers benefit from increased farm productivity.

The remainder of this chapter is organized as follows: In Section 6.2 an introduction to the Vietnamese dairy industry, the supply chain architecture and details on the standard dairy contract used are presented. Subsequently, the theoretical framework of our intervention is explained, followed by a description of the study area and the intervention. After lining out the identification strategy in Section 6.3, the results are presented in Section 6.4. Conceptual and methodological challenges with respect to the internal and external validity of the results are addressed in Section 6.5. This chapter closes with Section 6.6 in which we provide specific policy recommendations.

\subsection{Experimental design}

\subsubsection{Background on the Vietnamese dairy industry}

In Vietnam, much like in other countries of Asia, milk is becoming an increasingly popular food item leading to high growth rates of the sector. For example, only two decades ago the consumption levels of milk and dairy products were almost nil due to cultural practices, low incomes an resulting food consumption habits. But with increasing welfare levels, intensifying urbanization tendencies and the spread of Western lifestyle the demand for milk has increased tremendously. Today's per-capita consumption of milk in Vietnam has reached $15 \mathrm{~kg}$ per annum 
which is about 8 percent of the amount being consumed in the US or Europe. Currently, the Vietnamese dairy sector is dominated by local processing companies importing large quantities of powdered milk from overseas to satisfy the local demand in Vietnam. However, more and more milk is produced domestically, especially by small-scale farmers. Fresh milk production in Vietnam has tripled between 2003 and 2009, but still meeting only a fifth of domestic consumption (USDA, 2011).

The leader in the dynamic dairy industry - and cooperation partner in this field experiment—is formerly state-owned Vinamilk. This dairy processor collects the major share of milk produced in Vietnam and is a main importer of powdered milk. Currently, Vinamilk has contracted more than 5,000 small-scale dairy producers, most of them located around Vietnam’s largest city, HCMC.

\subsubsection{Supply-chain architecture and the standard contract}

In Vietnam, milk is produced mainly on specialized small-scale farms; crossbreed dairy cows are held in stables all year round. A major input is fodder; rations usually consist of forage produced on farms, complemented with purchased fodder, most importantly concentrate. Farmers usually sell the entire milk output to one dairy processor. Formal outside options are very limited; informal channels exist but can absorb only small quantities due to low demand for highly perishable raw milk in rural areas. Hence, small-scale dairy farmers who have undertaken relationship-specific investment have little bargaining power compared to large monopsonistic dairy processors.

The raw milk is channeled through MCCs which are located in the vicinity of the dairy farms (for a detailed description of the supply chain, refer to Chapter 4). 
Roughly 100 farmers supply an average MCC which is usually operated by private entrepreneurs working on commission for Vinamilk; some MCCs are collectively owned by farmers. Each MCC carries out the following tasks: Collection and handling of the milk twice a day, sampling of the milk, initial testing of quality (through external staff employed by the dairy processor) as well as daily transport of raw milk to Vinamilk’s dairies in urban centers; the MCCs also process the weekly payments to farmers.

The standard production contract between Vinamilk and dairy farmers is a country-wide standardized, written agreement, determining how much milk of what quality is purchased at which price. The output price for milk $p$ received by farmers is a function of milk quality $\theta$ which we write as:

$$
p=f(\theta)
$$

Quality is a composite measure of several parameters, most important total solid and milk fat content which depends on input use $x$ and a random shock $s$ (e.g. animal diseases, changing fodder quality) according to

$$
\theta=f(x, s)
$$

On a daily basis external Vinamilk staff deployed at the MCC takes milk samples individually for each farmer; one sample per week is randomly selected and analyzed in the dairy plant employing sophisticated laboratory methods. Producers have unique identification numbers and are paid individually according to their own output ( $q$ and $\theta$ ); the base price for top-quality milk is subject to harsh deductions if one or more of the quality parameters fall short the requirements set by the dairy company. As milk analyses are carried out in the company's own laboratory and hence cannot be observed by farmers, milk quality remains private information of the 
dairy company. Currently, smallholders cannot overcome the asymmetry of information regarding milk quality by systematically cross-checking the results provided by the processor because individual milk testing is prohibitively costly and collective action fails.

\subsubsection{A simple model of underinvestment}

In this subsection, drawing on a model described by Sandmo (1971), we formally derive how the asymmetric information on quality attributes described above leads to lower input use and suboptimal output compared to a situation of symmetric information. First, it assumed that the objective of farmers is to maximize expected utility of profits. The utility function is a well behaved, i.e. concave, continuous and differentiable function of dairy farming profits.

The farmer's cost function is defined as

$$
T(q)=V(q)+F
$$

where $\mathrm{q}$ is the output, $V(q)$ is the variable cost function and $\mathrm{F}$ represents the fixed cost. Further we assume that the cost function has the following properties:

$$
V(0)=0, \quad V^{\prime}(q)>0 .
$$

In a contract with incomplete but symmetric information the profit function can be defined as

$$
\pi(q)=p q-[V(q)+F]
$$

where the product of $p$ and $q$ is the total revenue (TR). Farmers maximize profits at the level of output where marginal revenue (MR) equals marginal costs (MC) according to

$$
M R=M C,
$$

where 


$$
\begin{gathered}
M R=\frac{\partial T R}{\partial q}=p \\
M C=\frac{\partial T}{\partial q}=T^{\prime}(q) .
\end{gathered}
$$

In this situation, $\theta$ is known to both participants in the transaction which implies that information about product quality is not complete but symmetric.

In contrast to the benchmark situation lined out above, we will now derive how the optimal input changes in an environment in which the buying company has private information about $\theta$, inducing underinvestment by sellers which in turn results in lower output. Exploiting its informational advantage, the dairy processor could report a lower level of quality to the farmer than implied by the results obtained in the laboratory. Hence, according to (6.1) withholding private information negatively affects the output price while increasing the residual income for the dairy processor. In a situation of asymmetric information a rational dairy producer $i$ forms a specific belief to what degree the milk company underreports. This is represented in the equation

$$
p_{i}^{\text {reported }}=\gamma_{i} p_{i}^{\text {true }}+\lambda_{\mathrm{i}}
$$

where the reported milk price $p_{i}^{\text {reported }}$ is the actual price $p_{i}^{\text {true }}$ based on the milk quality assessed in the laboratory, corrected by multiplicative and additive shift factors $\gamma_{i}$ and $\lambda_{\mathrm{i}}$. If $\gamma_{i}<1$ then $p_{i}^{\text {true }}$ is reduced proportionally; if $\lambda_{\mathrm{i}}<0$ a lump sum is deducted at any given level of $p_{i}^{\text {true }}$. For those farmer who believe that Vinamilk cheats we follow that

$$
p_{i}^{\text {reported }}<p_{i}^{\text {true }}
$$

If farmers maximize expected utility by setting marginal costs equal marginal revenue, the lower expected product price translates into lower marginal revenue. 
Hence, the optimal output level $q$ decreases given that farmers are price takers for inputs, and input prices remain unchanged.

Third-party contract enforcement would mitigate the negative effect on the expected output price level, because formerly unobservable quality attributes become verifiable for farmers, forcing the dairy company to report the real output quality and thus output price. In terms of the shift parameters this implies that $\gamma_{i}$ takes the value 1 while $\lambda_{\mathrm{i}}$ takes the value 0 . Hence, if plugged in to the profit function, the higher expected output price would according to (6.6) lead to more input use and higher output than in the current situation.

How can farmers practically respond to higher expected output prices? Generally, they can raise the output of milk fat and total solid-the value defining parts of the raw milk-in three ways: (a) Increase the quality (milk composition) while keeping the milk quantity constant, or (b) keep the quality constant while increasing the quantity, or (c) simultaneously increase quality and quantity.

On farm-level the goal of improving the absolute quantity of milk fat and total solid can be achieved in different ways. For example, in the short-run farmers can increase the amount of purchased fodder components (e.g. concentrate) to make the ration more nutritious, provided that the physiological requirements of dairy cows in terms of a balanced ration are still met. All other inputs are de-facto fixed in the short term. The supply of forage produced on the farm can only be increased in the medium or long run as additional land would have to be acquired which, however, requires capital. Likewise total herd output could be raised by increasing the herd size through buying cattle on the market or breeding. In the long-run 
selective breeding may also improve the herd's overall genetic potential for milk production.

\subsubsection{Design of the intervention and implementation}

After lining out the theoretical framework of third-party contract enforcement, in this section we describe the design and practical implementation of the intervention in which completely randomly selected dairy producers were provided with the opportunity to verify milk testing results provided by Vinamilk.

Every treatment farmer received three non-transferable vouchers, each valid for one independent analysis of milk quality (milk fat and total solid). Vouchers were meant to be executed whenever eligible farmers challenged the testing results reported by Vinamilk. Providing farmers with third-party quality verification implied setting up complex transport and testing logistics. For each milk sample obtained at the MCC under the original contract (hereafter A-sample), an additional identical sample (hereafter B-sample) had to be taken for each treatment farmer. The Bsample was sent to an independent and certified laboratory in HCMC and stored there. If a farmer executed a voucher, the B-sample was analyzed by the third-party laboratory and the testing results were reported by mail to the farmer. This allowed the farmer to compare if the results based on the A-sample reported by Vinamilk are identical to the results of the corresponding B-sample provided by the independent laboratory. While Vinamilk knows the identity of the treatment farmers, the actual execution of vouchers could not be observed, i.e. the dairy company did not know when an individual farmer in the treatment group executed her voucher. Hence, there was a constant threat to the company that any of the farmers in the treatment group could in any given week verify their testing results, effectively eliminating the 
possibility that Vinamilk behaves opportunistically. Compared to validating the results of each and every sample analyzed by Vinamilk, the voucher mechanism enabled us to implement a system to systematically overcome the information asymmetry on milk quality attributes at relatively low cost. All outlays arising from setting up a parallel testing infrastructure for the B-samples and milk analyses were borne by the project, ruling out that farmers would not request independent milk testing for cost reasons.

The logistics of the voucher treatment are complex. Thus, it was especially important that both treatment farmers delivering milk and Vinamilk staff taking the additional B-samples thoroughly understood the procedure. During a half-day workshop treatment farmers were informed about the independent milk testing works and learned how to use the vouchers. Every treatment farmer received written instructions supplementing the information presented during the workshop and was provided with a phone number of a trained field staff.

To assure that farmers regarded the third-party testing as credible and independent, we had identified a certified third-party laboratory which both farmers and Vinamilk explicitly agreed on. Further, to ensure the comparability of the A- and B-sample, we calibrated the third-party laboratory and Vinamilk's in-house laboratory using imported reference material. By employing the same cooling technology we also assured that during transport and storage the A- and B-samples were kept in identical environments with regard to factors potentially affecting milk quality such as temperature or exposure to sunlight.

To avoid contamination, i.e. that control group farmers get access to the thirdparty milk testing and thus effectively become treated, the emergence of a secondary 
market for vouchers had to be prevented. Hence, we handed out personalized vouchers tagged with a unique identification number. Vouchers passed on to other farmers (also outside the treatment group) automatically became invalid.

A scenario in which control farmers sell their milk through treatment farmers to benefit indirectly from the independent quality verification mechanism and resulting higher expected milk prices would confound the subsequent impact analysis, but is extremely unlikely. If a treatment farmer accepts milk from a fellow control group farmer (or an unknown source) she takes the risk to mix milk of unknown quality with her own milk, jeopardizing the milk quality of the whole batch delivered to the MCC, potentially leading to a lower milk price and a serious financial loss.

If take-up is voluntary in field experiments, individuals who are assigned to the treatment group may refuse to get treated. This may lead to low compliance rates which can be a challenge for the subsequent impact analysis. Cole et al. (2009) have found that adoption rates for innovative crop insurances in India were as low as 5 to 10 percent despite high potential benefits. Hill and Viceisza (2011) overcame the problem of low take-up in a framed field experiment by imposing mandatory insurance. Our intervention is special with respect to compliance in so far as for the voucher treatment to be effective a high compliance, i.e. high voucher execution rate is not a necessary condition. The specific design of the third-party contract enforcement does not depend on an individual farmer decision to execute a voucher to build a direct threat to Vinamilk. It is sufficient if farmer A forms the belief that farmers $\mathrm{B}$ or $\mathrm{C}$ may request an analysis; if $\mathrm{A}$ believes that $\mathrm{B}$ or $\mathrm{C}$ execute a voucher in a given week, this-from farmer A's point of view-would create an indirect but 
sufficiently powerful threat to the dairy processor to be monitored, ruling out underreporting. Ultimately, this implies that all farmers in the treatment group can be regarded as treated, regardless the compliance with respect to direct verification.

At this point also it should be stressed that when designing the voucher treatment, we were interested in isolating the general effect of third-party contract enforcement, rather than evaluating a particular way of providing farmers with independent testing of yet unobservable quality attributes. Like in the case of Thomas et al. (2003) who have investigated the impact of an iron-supplementation program, our voucher-based approach is too costly to be easily scaled up. In a nonexperimental setting complete outsourcing of milk testing to an independent laboratory would be more efficient than establishing a parallel-structure for B-sample analyses. Successful examples of outsourcing of quality assessment exist in countries such as Germany where independent milk testing has been implemented several decades ago.

\subsubsection{Study area, sample and randomization}

Almost 70 percent of the domestically produced milk in Vietnam stems from the region around HCMC. The study area is located in Long An and Tien Giang, two representative provinces south of HCMC where Vinamilk has contracted 402 dairy farmers. The milk supply is channeled through four MCCs.

On MCC-level differences with respect to average dairy output (quantity, quality) can be observed (Table A1 in the Appendix). We attribute this to selection effects rather than geographical differences. As three out of the four collection centers in the study area (MCC B, C and D) are spatially clustered, it is unlikely that for example agro-ecological factors cause the performance differential. As farmers 
can choose freely which MCC to supply their milk to, we suppose that selection based on unobservables may cause the farmer population of one MCC to systematically differ from farmers at other MCCs. For example, dairy producers do not only choose an MCC based on the distance between their farm and the MCC but also based on soft factors such as trust towards the management of the MCC. Besides the three clustered MCCs there is also one more isolated collection center (MCC A) where farmers-in contrast to the MCC cluster-do not have the option to choose different Vinamilk MCCs. However, a competitor of Vinamilk sources raw milk in the area of MCC A. Hence, farmers could entirely switch to the competing dairy processor, e.g. if they are discontent with Vinamilk, the contract or the collection center management. We follow, that on average those farmers who deliberately keep delivering to Vinamilk despite having an outside option for some reason (e.g milk price or identification with Vinamilk as an organization) are systematically different from those Vinamilk farmers without such an outside option. In the subsequent impact analysis we take these selection effects into account.

Given the limited number of MCCs and significant mean differences in observable characteristics between the MCCs, a randomization of treatment status over MCCs—even though easier to manage-would not be useful (for a comparison of selected outcome variables, see Table A1). Hence, in May 2009 the entire population of 402 dairy farmers attended a public lottery in which 102 farmers were completely randomly assigned to the treatment group. Another 100 farmers were completely randomly assigned to the control group, continuing to produce under the original, incomplete contract without enforcement. Farmers were informed that due to a budget constraint and for the sake of a clear evaluation of the project - the term 
experiment was avoided when communicating with farmers due to its negative connotation — only a limited number of slots would be available in the treatment group. Especially the latter justification was needed to maintain control group farmers motivated to participate in the follow-up survey. Due to the complexity of the treatment design, the implementation had to be delayed several times. The intervention eventually started in May 2010 when the first batch of B-samples was obtained.

\subsubsection{Data}

We collected detailed information for all farmers participating in the experiment. Through two rounds of structured household surveys we generated a panel data set comprising socio-economic data on dairy production, income from agricultural and non-agricultural activities, household expenditure and assets owned. Additionally, questions measuring social capital, trust, time- and risk-preferences were included in the questionnaire. The first round of interviews, the baseline survey, took place in May 2009 before the experiment started. In May/June 2011, all farmers were revisited for the follow-up survey when the experiment was completed. The household data were complemented with rich farm-level output data for each producer in the sample for data provided by the dairy processor, for the period from May 2008 to May 2011 covering 24 months prior to the intervention and the time period of the intervention. On the one hand, it can be assumed that these data are of higher quality than self-reported recall data on output obtained through household surveys, as this weekly reported information—disaggregated by milk quantity and three quality parameters - is the basis for farmers' payment. On the other hand, the dairy company may have an incentive to strategically release information, i.e. 
provide manipulated data to mask underreporting of milk quality and price in case farmers were cheated before the intervention. We carefully address this issue in subsection 6.5.2 when discussing the internal validity of the results.

\subsection{Analytical approach}

\subsubsection{Identification strategy and econometric estimation}

The impact of third-party quality verification is assessed in three dimensions: (a) input use in dairy production, (b) output generation in dairy production, and (c) welfare of the farming household.

While (a) is measured by the amount of purchased fodder (concentrate) used per cow and day reported by farmers, (b) is captured first by three variables, the total amount of milk fat and total solid produced during the twelve months when the experiment was ongoing and revenues from dairy farming for the same time period. Data on both output variables are provided by the dairy company. For (c) we use total annual household expenditures on food (own produced food items were valued at the market price), other consumer goods and durables obtained through the household survey.

We seek to identify two types of treatment effects. First, the average treatment effect on the treated (ATT) which is estimated according to

$$
A T T=E\left(y_{1}-y_{0} \mid v=1\right)
$$

where ATT is the difference of $y_{1}$, the average outcome of the treated and $y_{0}$, the counterfactual outcome of the untreated conditioned on the treatment status $v=1$ which means being treated. Given the random assignment of $v$, the control group constitutes an adequate counterfactual of the treatment group. 
Second, we are interested in the average treatment effect on the treated conditional on specific baseline covariates $\mathrm{x}$. To estimate this heterogeneous treatment effect, we condition ATT on $\mathrm{x}$ according to

$$
\operatorname{ATT}(x)=E\left(y_{1}-y_{0} \mid x, v=1\right) \text {. }
$$

To estimate ATT and ATT(x) econometrically, we employ a multivariate regression framework and specify an OLS regression model according to

$$
y=\propto+\beta v+\gamma \boldsymbol{X}+\delta v \boldsymbol{X}+\varepsilon,
$$

where the dependent variable $\mathrm{y}$ is an outcome variable measured at the end of the experiment.

For each outcome variable under investigation we specify two distinct regression models. In the first specification which aims at identifying ATT we include the treatment dummy $v$ which takes the value 1 if an individual was assigned to the treatment group and 0 otherwise. To measure ATT(x) the model is augmented by adding a vector $X$ of dummy variables indicating baseline characteristics at time $t_{0}$. which allows for testing whether the relationship between baseline characteristics and outcome variables is different conditional on treatment status The variable baseline trust which is a dummy variable taking the value 1 if farmers agreed with the statement that "Vinamilk is a trustworthy business partner" and 0 otherwise. ${ }^{7}$

We suppose that initial trust levels may affect the impact intensity of the voucher. For example, farmers already trustful in the baseline may be less affected by an intervention that aims at ruling out potential opportunistic behavior from Vinamilk.

\footnotetext{
${ }^{7}$ In the baseline survey interviewees had to rate this statement on a four-point Likert-scale ("very much agree”, “agree”, “disagree”, "very much disagree”; the option "I don’t know” was also included). We collapsed the responses into a dummy taking the value 1 if farmers opted for "agree" or "fully agree" and 0 otherwise.
} 
Second, the dummy variables indicating the affiliation to a specific milk collection center (MCC B, MCC C and MCC D; MCC A was chosen as benchmark) capture the effect of unobserved characteristics that make farmers select a specific MCC to deliver their milk (see also Section 6.2.5).

\subsubsection{Randomization}

Prior to the impact analysis we have verified that both treatment and control group are similar statistically with respect to the large number of observables available from the baseline survey (Table 6.1). The only statistically significant (at 10 percent error rate) differences we find are for the variables capturing road infrastructure and time preferences ${ }^{8}$, indicating that treatment farmers are located slightly closer to paved roads and are less patient than their peers in the control group. But given the random assignment of the treatment status, the observed differences are not systematic, e.g. better infrastructure did not make this household more likely to be assigned to the treatment group ${ }^{9}$.

\subsubsection{Attrition}

Between the baseline survey in May 2009 and the implementation of the treatment in May 2010 a number of milk farmers ceased production or switched from Vinamilk to the competing dairy processor. The number of households in the treatment and control group decreased from 100 and 102 to 93 and 91, respectively. Those producers dropping out of the sample have statistically significant (at 10

\footnotetext{
${ }^{8}$ In the baseline survey we revealed through a battery of choices between hypothetical payoffs the discount rates at which farmers accepted to wait for one month to receive a significant lump sum payment. The variable was converted into a dummy variable which takes the value 1 if farmers agreed to wait one month if a monthly interest rate of up to $3.5 \%$ is paid.

${ }^{9}$ As robustness check both variables were included in the regression equation but their inclusion neither led to significant coefficients for these variables nor to notable changes in the treatment effects (results are not presented here).
} 
percent level) smaller baseline heard sizes, are less productive and have lower revenues from milk. The attrition rate is balanced between treatment and control group.

Table 6.1: Differences in selected baseline variables for treatment and control group

\begin{tabular}{lcc}
\hline \hline & Control -Voucher & SE \\
\hline \hline Basic household characteristics & & 1.558 \\
\multicolumn{1}{c}{ Age of HH-head (in yrs) } & 1.233 & 0.442 \\
Education HH head (in yrs of schooling) & 0.556 & 0.183 \\
Number of HH member & 0.0725 & 783 \\
Total land size (in m ${ }^{2}$ ) & 893 & 0.122 \\
Distance to paved road (in km) & $-0.270^{*}$ & 0.0687 \\
If agree to postpone at interest rate $<=3.5 \%(1=y)$ & \\
Dairy enterprise & $-0.183 * *$ & 0.0632 \\
Delivers milk to MCC A (1=y) & & 0.0638 \\
Delivers milk to MCC B (1=y) & 0.0331 & 0.0645 \\
Delivers milk to MCC C (1=y) & -0.0979 & 0.0647 \\
Delivers milk to MCC D (1=y) & 0.0650 & 1.8262 \\
Daily concentrate per cow (in kg) & -0.0002 & 59.9960 \\
Absolute milk fat (in kg) & 1.6259 & 194.6577 \\
Absolute total solid (in kg) & -53.5189 & 550.2339 \\
Annual revenue from dairy (in USD) & -173.3415 & 111.4629 \\
Household expenditure & -432.4991 & \\
Annual HH-expenditure (in USD) & & \\
\hline \hline
\end{tabular}

*** $\mathrm{p}<0.01, * * \mathrm{p}<0.05, * \mathrm{p}<0.10$ Source: Own data 


\subsubsection{Compliance}

As pointed out in Section 6.2.4 the intervention did not require high compliance rates (primary enforcement), i.e. voucher being executed by a large number or farmers, in order to be effective. However, from treatment farmers' perspective a minimum compliance in the treatment group is (psychologically) desirable to credibly build up the threat to the dairy processor of being effectively monitored.

We find that only seven farmers (out of 93) have actually requested independent verification of milk testing results despite it is easy, cheap and safe. It is worthwhile mentioning that those farmers who have executed vouchers on average had larger herd sizes with more productive dairy cows. A possible explanation for this observation could be that these large farmers had a higher interest in verifying the milk testing results provided by the processor as even little underreporting of milk quality and thus milk prices would lead to substantial losses due to the higher production volume. We have systematically evaluated the voucher treatment in the follow-up survey to identify reasons for low take-up rates; selected results are presented in Figure 6.1. The majority of farmers who have not executed vouchers agreed that third-party quality assessment was useful, easy to request, and trusted the independent laboratory. Roughly 50 percent of all treatment farmers stated to not have executed a voucher because they were content with the milk quality results provided by Vinamilk while the experiment was ongoing. Half of the farmers indicated they would feel uneasy to secretly check up on Vinamilk.

It should be stressed again that due to the fact that indirect threat is sufficient for the voucher treatment to be effective the low execution rate of vouchers does not 
pose a problem to the subsequent impact analysis; hence, all individual assigned to the treatment group (expect for drop-outs) can be regarded as treated.

Panel (a)

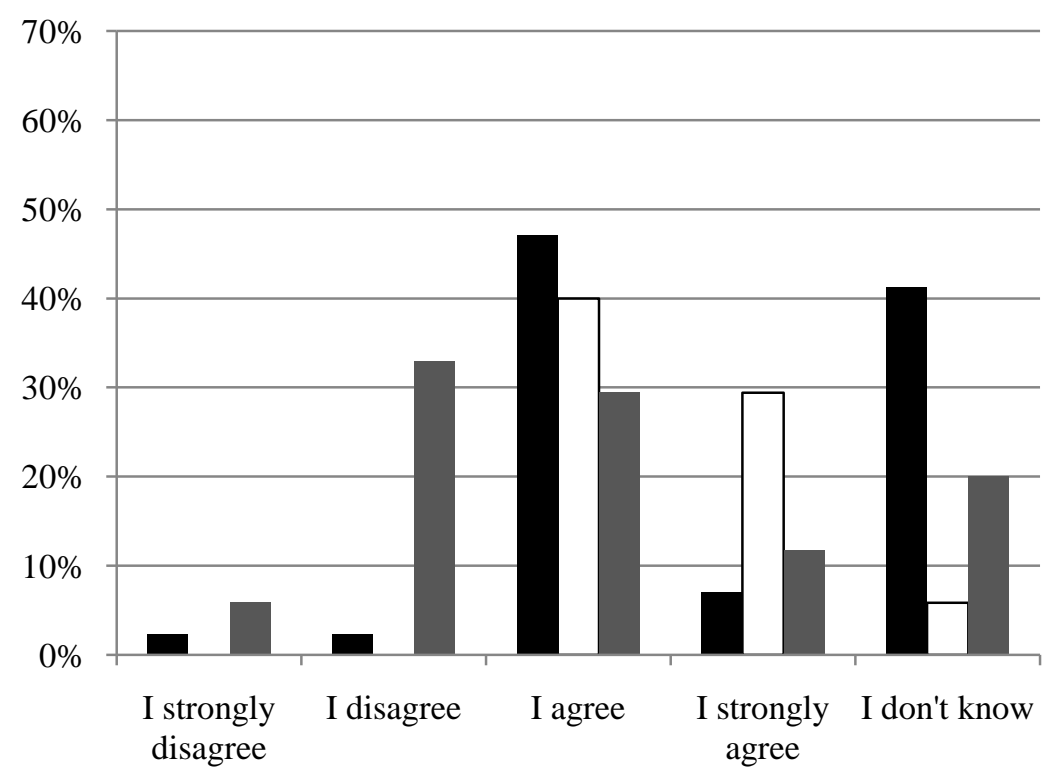

- It is easy to execute the voucher

$\square$ I haven't executed the voucher because milk quality was good

I don't feel comfortable double checking behind Vinamilk's back

Panel (b)

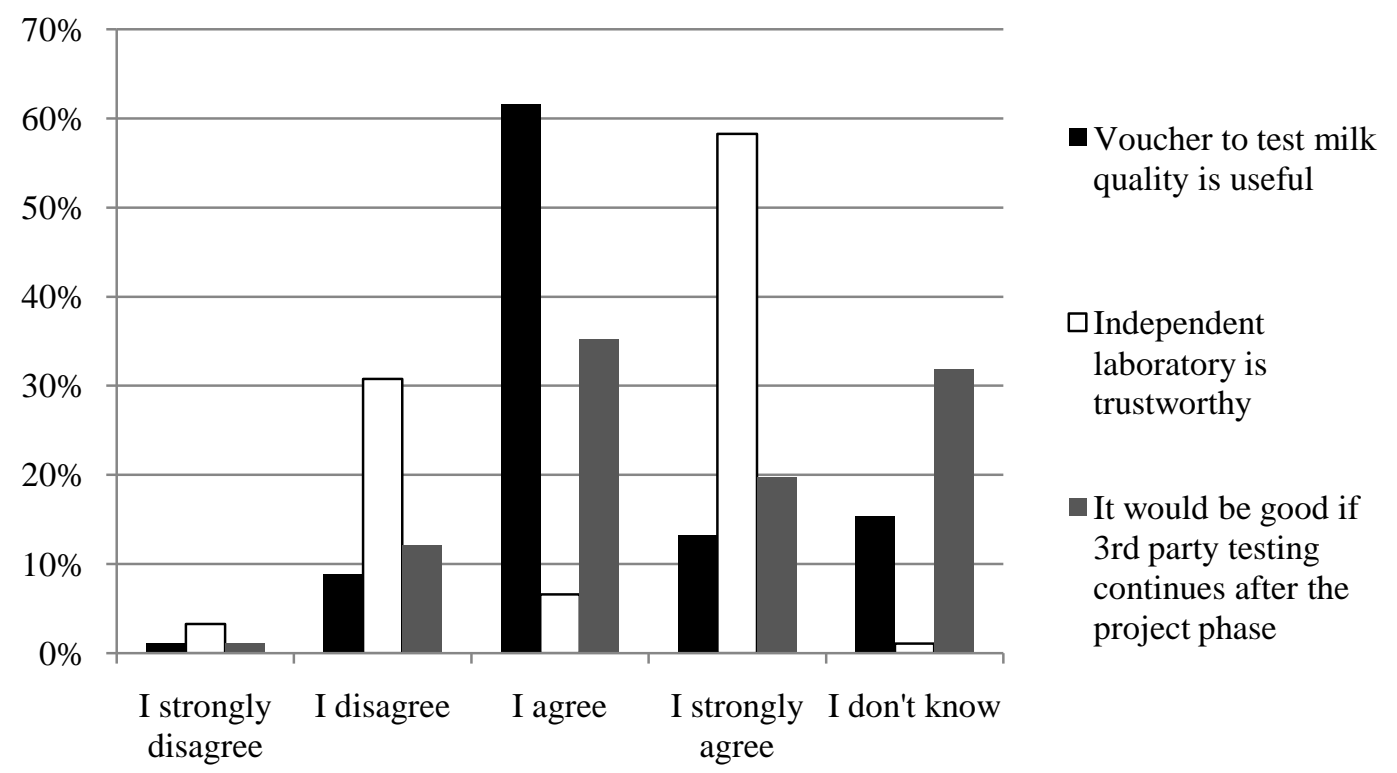

Figure 6.1: Farmers who have not executed a voucher evaluate the treatment $(n=86)$ Source: Own data 


\subsection{Estimation results}

\subsubsection{Input}

First we investigate how the treatment affects self-reported fodder usage (concentrate fed per cow and day in kg). Results are presented in Table 6.2, columns (1) and (2). We find a highly significant positive treatment effect which is robust across both specifications. Farmers in the treatment group on average fed their cows 13 percent more purchased concentrate than their peers in the control group. The coefficients of the additional control variables, baseline trust towards the dairy company and the affiliation to a specific collection center are insignificant across all specifications. As we do not find a significant effect for the interaction terms, it seems that the level and significance of the treatment effect is homogenous with respect to the treatment group; the effect of the intervention does not differ for farmers who were trustful towards Vinamilk in the baseline or those affiliated to MCC B, C or D.

Besides the amount of purchased concentrate which makes up the largest share of total input costs, we also analyzed the treatment effect with respect to labor, veterinary services and artificial insemination. However, for these inputs we do not find significant differences between treatment and control group.

\subsubsection{Output}

The regression results for dairy output are also presented in Table 6.2. If baseline trust and collection center affiliation are controlled for, we find a significantly positive treatment effect with respect to the absolute amount of milk fat and total solid produced during the twelve months period of the experiment as can be seen in columns (3) to (6). Apparently the increased production intensity (use of 
purchased concentrate) had translated into a higher absolute output of valuable milk fat and total solid. In contrast, the relative composition of milk remained constant as suggested by mean comparisons of total solid and fat content before and after the treatment; likewise running the above specified regression models with average total solid and fat content as dependent variables, no significant impact of the treatment was found (results not presented here).

In Section 6.2.3 we had proposed three ways how farm-level dairy output can be increased. The results suggest that farmers mainly chose the second approach, namely increasing the milk quantity (in kg) while keeping quality (milk fat and total solid content in percent) constant. A possible explanation for the observed increase in milk quantity but unchanged milk quality (fat and total solid content in percent) can be found in the physiology of dairy cows. To produce large quantities of milk, the dairy cow requires a nutritious but also balanced fodder ration, especially with respect to protein and energy content of the fodder. If the dairy cow is fed suboptimal levels of one of the two components, the milk yield drops. For example, if the ration contains too little protein relative to energy, the ruminal protein-balance is negative depressing the milk yield (Roth et al., 2011). As the concentrate increasingly purchased by farmers in the treatment group is rich on protein, it is plausible that, for example, a formerly negative protein-balance was not binding anymore. As a result this would have effectively alleviated the constraining effect of low proteinavailability and boosted the per-cow milk yield without changing the milk composition with respect to milk fat and total solid content. Besides that, the higher output may be partially attributed to a slight (but statistically not significant) increase of the average herd size in the treatment group. 
Table 6.2: Estimation results (OLS-model)

\begin{tabular}{|c|c|c|c|c|c|c|c|c|c|c|}
\hline & \multicolumn{2}{|c|}{$\begin{array}{c}\text { Input } \\
\text { Daily concentrate per cow } \\
\text { (in kg) }\end{array}$} & \multicolumn{4}{|c|}{ Output } & \multicolumn{2}{|c|}{$\begin{array}{c}\text { Revenue } \\
\text { Annual from dairy } \\
\text { (in USD) }\end{array}$} & \multicolumn{2}{|c|}{$\begin{array}{c}\text { Welfare } \\
\text { Annual HH-expenditure } \\
\text { (in USD) }\end{array}$} \\
\hline & $\begin{array}{l}\text { ATT } \\
\text { (1) }\end{array}$ & $\begin{array}{l}\operatorname{ATT}(x) \\
(2)\end{array}$ & $\begin{array}{l}\text { ATT } \\
\text { (3) } \\
\end{array}$ & $\begin{array}{l}\operatorname{ATT}(x) \\
(4)\end{array}$ & $\begin{array}{l}\text { ATT } \\
\mathbf{( 5 )} \\
\end{array}$ & $\begin{array}{l}\operatorname{ATT}(x) \\
(\mathbf{6})\end{array}$ & $\begin{array}{l}\mathrm{ATT} \\
\mathbf{( 7 )} \\
\end{array}$ & $\begin{array}{l}\operatorname{ATT}(x) \\
\text { (8) }\end{array}$ & $\begin{array}{l}\text { ATT } \\
\mathbf{( 9 )} \\
\end{array}$ & $\begin{array}{l}\operatorname{ATT}(x) \\
(\mathbf{1 0})\end{array}$ \\
\hline Voucher treatment (1=y) & $\begin{array}{l}0.913^{* * *} \\
{[0.280]}\end{array}$ & $\begin{array}{l}1.333 * * \\
{[0.631]}\end{array}$ & $\begin{array}{l}46.63 \\
{[76.80]}\end{array}$ & $\begin{array}{l}357.0 * * \\
{[179.6]}\end{array}$ & $\begin{array}{l}150.6 \\
{[242.4]}\end{array}$ & $\begin{array}{l}1,137 * * \\
{[568.8]}\end{array}$ & $\begin{array}{l}519.9 \\
{[923.7]}\end{array}$ & $\begin{array}{l}4,022 * \\
{[2,183]}\end{array}$ & $\begin{array}{l}184.5 \\
{[517.5]}\end{array}$ & $\begin{array}{l}-1,300 \\
{[1,262]}\end{array}$ \\
\hline Trust towards Vinamilk (1=y) & & $\begin{array}{l}-0.0475 \\
{[0.374]}\end{array}$ & & $\begin{array}{l}178.2 \\
{[110.6]}\end{array}$ & & $\begin{array}{l}573.8 \\
{[350.3]}\end{array}$ & & $\begin{array}{l}2,519 \\
{[1,862]}\end{array}$ & & $\begin{array}{l}-552.8 \\
{[754.8]}\end{array}$ \\
\hline Vinamilk Trust $*$ Voucher & & $\begin{array}{l}-0.722 \\
{[0.538]}\end{array}$ & & $\begin{array}{l}-135.4 \\
{[154.6]}\end{array}$ & & $\begin{array}{l}-439.4 \\
{[489.6]}\end{array}$ & & $\begin{array}{l}46.51 \\
{[2,068]}\end{array}$ & & $\begin{array}{l}2,164 * * \\
{[1,072]}\end{array}$ \\
\hline Collection Center B (1=y) & & $\begin{array}{l}-0.834 \\
{[0.542]}\end{array}$ & & $\begin{array}{l}146.4 \\
{[153.2]}\end{array}$ & & $\begin{array}{l}482.4 \\
{[485.2]}\end{array}$ & & $\begin{array}{l}2,279 \\
{[2,068]}\end{array}$ & & $\begin{array}{l}-577.0 \\
{[1,074]}\end{array}$ \\
\hline Collection Center C (1=y) & & $\begin{array}{l}-0.746 \\
{[0.577]}\end{array}$ & & $\begin{array}{l}-51.68 \\
{[170.2]}\end{array}$ & & $\begin{array}{l}-142.3 \\
{[538.9]}\end{array}$ & & $\begin{array}{l}-1,321 \\
{[2,619]}\end{array}$ & & $\begin{array}{l}-1,246 \\
{[1,152]}\end{array}$ \\
\hline Collection Center D (1=y) & & $\begin{array}{l}0.304 \\
{[0.591]}\end{array}$ & & $\begin{array}{l}122.7 \\
{[170.2]}\end{array}$ & & $\begin{array}{l}414.5 \\
{[538.9]}\end{array}$ & & $\begin{array}{l}-2,455 \\
{[2,711]}\end{array}$ & & $\begin{array}{l}-1,145 \\
{[1,180]}\end{array}$ \\
\hline Collection Center B * Voucher & & $\begin{array}{l}0.528 \\
{[0.760]}\end{array}$ & & $\begin{array}{l}-108.8 \\
{[215.5]}\end{array}$ & & $\begin{array}{l}-385.5 \\
{[682.4]}\end{array}$ & & $\begin{array}{l}-5,054^{*} \\
{[2,701]}\end{array}$ & & $\begin{array}{l}-1,027 \\
{[1,515]}\end{array}$ \\
\hline Collection Center C * Voucher & & $\begin{array}{l}-1.298 * \\
{[0.775]}\end{array}$ & & $\begin{array}{l}-252.7 \\
{[223.1]}\end{array}$ & & $\begin{array}{l}-771.0 \\
{[706.4]}\end{array}$ & & $\begin{array}{l}2,233 * \\
{[1,345]}\end{array}$ & & $\begin{array}{l}1,967 \\
{[1,537]}\end{array}$ \\
\hline Collection Center D * Voucher & & $\begin{array}{l}0.165 \\
{[0.778]}\end{array}$ & & $\begin{array}{l}-458.1 * * \\
{[222.3]}\end{array}$ & & $\begin{array}{l}-1,443^{* *} \\
{[703.8]}\end{array}$ & & $\begin{array}{l}-1,639 \\
{[1,879]}\end{array}$ & & $\begin{array}{l}599.6 \\
{[1,552]}\end{array}$ \\
\hline Constant & $\begin{array}{l}6.864 * * * \\
{[0.202]}\end{array}$ & $\begin{array}{l}7.295 * * * \\
{[0.483]}\end{array}$ & $\begin{array}{l}572.7 * * * \\
{[56.59]}\end{array}$ & $\begin{array}{l}419.0^{* * *} \\
{[137.5]}\end{array}$ & $\begin{array}{l}1,811^{* * *} \\
{[178.7]}\end{array}$ & $\begin{array}{l}1,303 * * * \\
{[435.4]}\end{array}$ & $\begin{array}{l}\text { 6,819*** } \\
{[680.7]}\end{array}$ & $\begin{array}{l}4,333^{* *} \\
{[1,671]}\end{array}$ & $\begin{array}{l}4,120 * * * \\
{[375.2]}\end{array}$ & $\begin{array}{l}\text { 5,134**** } \\
{[963.1]}\end{array}$ \\
\hline Observations $^{1}$ & 150 & 148 & 151 & 149 & 151 & 149 & 151 & 149 & 156 & 154 \\
\hline R-squared & 0.067 & 0.257 & 0.002 & 0.109 & 0.003 & 0.104 & 0.002 & 0.090 & 0.001 & 0.062 \\
\hline
\end{tabular}

Standard errors in brackets; $* * * \mathrm{p}<0.01,{ }^{* *} \mathrm{p}<0.05,{ }^{*} \mathrm{p}<0.10 ;{ }^{1}$ The number of observation varies because of randomly missing values for specific dependent or independent variables Source: Own data 
The increase in output leads to higher revenues from dairy production which is presented in Table 6.2, columns (7) and (8). The positive and significant (at 10 percent error rate) coefficient of the treatment dummy in the second model in which baseline characteristics are controlled for points to a heterogeneous treatment effect, especially with respect to milk collection center affiliation. The increment in revenue can entirely be attributed to the increased production volume as the milk price remained constant.

\subsubsection{Welfare}

Finally, we look into the intervention's impact on total household expenditures, a relatively stable measure of welfare that adjusts rather slowly to moderate positive or negative income shocks. We observe a welfare increase for the subgroup of treatment farmers that was trustful towards the company before the experiment started (high-trust farmers), as presented in Table 6.2, columns (9) and (10). This can be inferred from the positively significant coefficient of the interaction term Vinamilk Trust*Voucher. So far, the impact evaluation with respect to all other outcome variables of interest has not provided any evidence that low-trust farmers are more strongly affected by the treatment than high-trust farmers. The coefficient of the interaction term Vinamilk Trust*Voucher has not been statistically significant in any of the prior models. Indeed, it seems reasonable that even high-trust farmers might form the belief that Vinamilk cheated before the intervention started, given the supply chain architecture and the realistic threat of opportunistic behavior.

Further, given the specific way we measured trust variable, it could capture trust in more than only one dimension. The statement "Vinamilk is a trustworthy business partner” that had to be rated by survey respondents probably does not only 
capture the belief about Vinamilk's quality reporting strategy, but also beliefs regarding timing of payment or assumptions about Vinamilk's long-term commitment to output price levels fixed when the contract was initially signed.

If this is the case, low-trust farmers may perceive the entire relationship to Vinamilk as riskier, and act more cautiously. Given the relatively short time horizon of the intervention and the slowly adjusting welfare measure we use, the time period of observation might have been too short to find an increase in household spending for low-trust farmers. Instead of increasing expenditures as their high-trust peers, low-trust farmers may instead have saved more money building up a safety buffer to prepare for future shocks (which they perceive as being more likely), e.g. Vinamilk lowering the output price for milk price.

\subsection{Discussion}

Overall our findings confirm the formally derived hypothesis that third-party enforcement of contracts mitigates underinvestment and hence are in line with Wu's and Roe’s (2007) findings from laboratory experiments with college students. Furthermore this study shows under real-world conditions that higher input levels observed under the enforced contract actually translate into higher output, a result which would impossible to obtain in the laboratory as the underlying technology and possible supply response would be predetermined by the experimenters. The findings also suggest that on average specific subgroups are affected to varying degrees by the intervention, especially those delivering to particular collection centers. Given the available data we are not able to open the black box of collection center affiliation to identify clear mechanisms behind this particular finding. However, we suppose that 
selection on unobservables (e.g. identification with an MCC or dairy processor) into specific MCCs may explain the discrepancy of impact.

\subsubsection{Contamination}

As pointed out in Section 6.2.4 we avoided control farmers getting direct access to third-party quality assessment by issuing personalized vouchers to treatment farmers. However, the completely random assignment of the treatment status may still have led to positive contamination. Farmers in the control group could have gotten indirect access to the treatment through trust-spillovers: For example, if a control group farmer for some reason updated her belief about Vinamilk’s type from “unfair” to “fair” after communicating with a neighboring treatment farmer. We evaluated this through specific questions in the follow-up survey. The results suggest that positive contamination might have occurred, since the trust levels ${ }^{10}$ significantly increased in both treatment and control group (though more for treatment farmers). From this we follow that the treatment effect we measured actually underestimates the real impact of third-party contract enforcement. A cleaner design, less susceptive to positive contamination, would have implied to strictly separate treatment and control farmers, to avoid communication between members of the different groups. However, choosing the milk collection center as unit of randomization would have been prohibitively costly in terms of budget requirements and administrative burden due to the large number of collection centers needed for proper randomization.

\footnotetext{
${ }^{10}$ Trust levels were measured before and after the treatment. The variable is constructed in the same way as baseline trust, explained in detail in Section 6.3.1.
} 


\subsubsection{Data provision and incentive compatibility}

In the results section above, we attributed the entire treatment effect to a behavioral change of treatment farmers, not (partly) to a change in Vinamilk's reporting behavior. If the company had underreported output quality (total solid and fat content) until the point in time the independent quality verification was implemented, we would not be able to disentangle the observed differential in output and attribute it either to farmers or the company. In the most extreme case, higher observed output quality would entirely be the result of Vinamilk stop underreporting quality.

In this section we will become explicit about how we infer from the available data that Vinamilk's type is "fair" with respect to reporting milk testing results and prices, allowing us to fully attribute the observed changes in output to farmers. Further we will elaborate what this finding means in the context of the second research question, i.e. if third-party contract enforcement has positive welfare implications (for smallholders).

Before we analyze patterns in the data to reveal if Vinamilk deliberately underreported milk quality and thus the price of output or not, let us first introduce a little bit of notation: We choose $t_{0}$ to represent the starting point of the intervention and label $t_{+1}$ the point when the intervention ended after twelve months; $t_{-1}$ marks the point in time, twelve months prior to the intervention. We distinguish between the output (quantity and quality) reported by Vinamilk and the real output obtained using laboratory methods which in case of quality is private information. If Vinamilk had exploited the informational advantage, reported output levels would have been lower than true output levels. If instead Vinamilk played fair, reported and true output 
levels would have been identical. This is shown in a stylized way in Figure 6.2 in which reported output for the treatment group is represented by a solid line, true output by a dashed line.

In the results section we had shown that independent verification of quality attributes made farmers produce more milk fat and more total solid in the interval [ $\mathrm{t}_{0}$, $t_{+1}$ ] than during interval $\left[t_{-1}, t_{0}[\right.$. As already pointed out, this is the result of an increase in milk quantity $q$ at constant milk quality levels $\theta$. The positive net-effect on $q$ is graphically represented in Figure 6.2 by the non-zero slope in reported average quantity delivered to the company in the domain $\left[t_{0}, t_{+1}\right]$. It is important to note that the amount of milk delivered has always been observable to both selling farmers and the buying company as milk is weighed under the eyes of the farmers at the MCC. Hence, there has never been an asymmetry of information with respect to the milk quantity. As a result reported and true output must be identical, which is indicated by the coinciding dashed and solid lines. ${ }^{11}$ Thus, the observed treatment effect with respect to $q$ can unambiguously be attributed to a change in farmers' input use.

While $q$ increased, levels of $\theta$ were not affected by the intervention as already pointed out in the Section 6.4.2. For the interval $\left[t_{0}, t_{+1}\right]$ in which quality was verifiable through the independent laboratory we know with certainty that reported $\theta$ and true $\theta$ must be identical. This is graphically depicted in Figure 6.2 by the coinciding solid and dashed lines for the domain $\left[\mathrm{t}_{0}, \mathrm{t}_{+1}\right]$.

\footnotetext{
${ }^{11}$ For illustrative purposes, the coinciding solid and dashed lines have been separated in the graphs.
} 


\begin{tabular}{|lllll|}
\hline q: milk quantity & & reported & $\mathrm{t}_{-1}$ & twelve months before experiment \\
$\theta$ : milk quality & & true in case of manipulation & $\mathrm{t}_{-0}$ & experiment starts \\
& & true in case of no manipulation & $\mathrm{t}_{+1}$ & experiment ends \\
\hline
\end{tabular}

$\mathbf{q}$

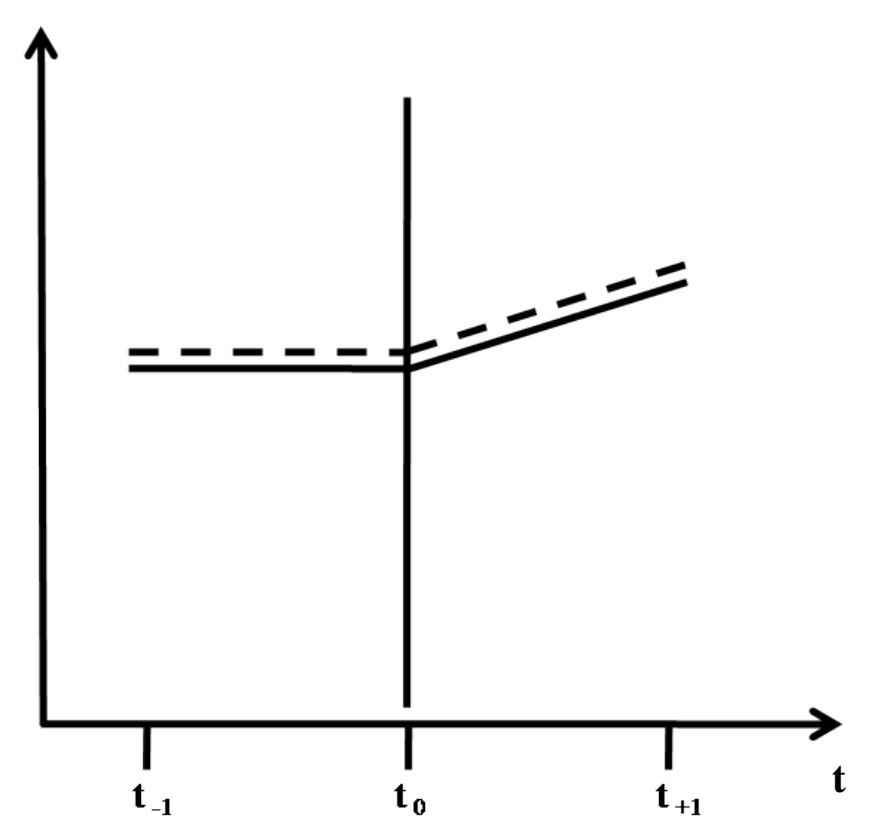

$\boldsymbol{\theta}$

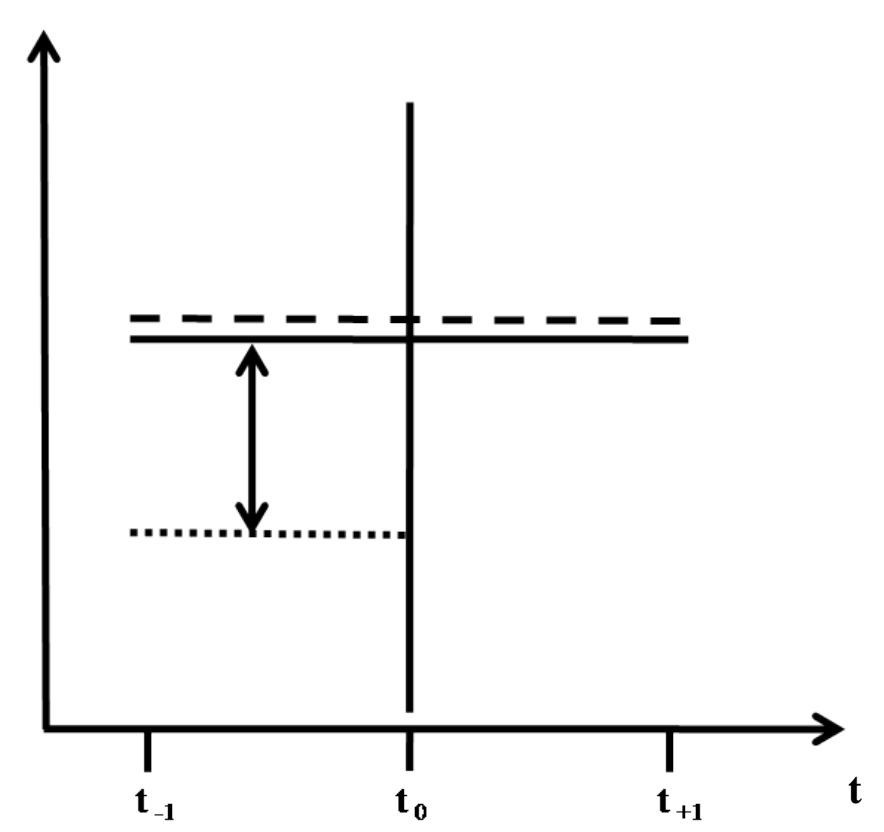

Figure 6.2: Stylized development of output levels (treatment group) Source: Own data 
If the dairy processor cheated before $t_{0}$ and stopped behaving opportunistically as soon as the third-party testing was implemented, we would have been able to identify a jump in the reported average quality between the intervals [ $\mathrm{t}_{0}$, $\left.\mathrm{t}_{+1}\right]$ and $\left[\mathrm{t}_{-1}, \mathrm{t}_{0}[\right.$. However, we do not find such a jump.

Before we can infer that Vinamilk did not underreport in [ $\mathrm{t}_{-1}, \mathrm{t}_{0}[$, we need to rule out an alternative explanation for the pattern found in the data: Vinamilk could have stopped cheating farmers as soon as they learned about the nature of our intervention. In this case Vinamilk would already have stopped underreporting at some point before $t_{0}$ to avoid providing evidence for cheating. This alternative explanation can be ruled out as Vinamilk had already provided the first batch of production data (quantity and quality) in a very early stage of our cooperation when exploratory talks were taking place and we had not yet come up with this specific intervention involving verification of milk testing results. Hence, we had received data at a point in time when Vinamilk could not have possibly anticipated what exact type of intervention we were proposing to implement and evaluate. This precludes that the dairy company provided us with "tailored" data to mask strategic underreporting of quality.

\subsubsection{A story of moral hazard or signaling?}

Putting all these pieces of evidence together, we conclude that the company has not been deliberately underreporting milk quality and price, neither in $\left[\mathrm{t}_{-1}, \mathrm{t}_{0}[\right.$ nor in $\left[t_{0}, t_{+1}\right]$. This however sheds new and interesting light on the evaluation of the overall effect of mitigating asymmetric information in our specific case. Apparently, we did not identify a situation in which the principal (Vinamilk) was behaving opportunistically (at least in the domain of quality testing), exploiting the advantage 
of having private information. Instead we infer that Vinamilk could not send a credible signal to farmers that it is not cheating, because of the supply chain architecture: the Vietnamese dairy sector lacks an independent body for milk quality assessment. Hence, rational agents (dairy farmers) formed the belief that the principal underreports quality. As a result they lowered their expectations about the output price, responded to by suboptimal input use, leading to lower output. This is an important finding as it also has implications for the distribution of possible gains from third-party contract enforcement. If the company did not cheat in the first place, it no information rents could be accrued (potentially outweighing the losses from farmers' suboptimal milk output and hence making cheating the dominant strategy). Thus, in a situation in which the principal plays "fair" but is unable to send a credible signal of his type, third-party verification leads to a Pareto improvement, increasing the welfare of both agent and principal. Per-unit transaction costs for the procuring company decrease if farmers produce more output in a situation of symmetric information. This also is also crucial for smallholder participation in emerging highvalue markets, as high transaction costs are one reason why processors tend to prefer contracting larger farmers (Birthal et al., 2005).

\subsection{Conclusion}

Contract farming has become a widely embraced approach to facilitate supply chain relations between selling farmers and buyers such as processing companies or wholesalers, not only in the developed world but also in developing countries, especially in emerging markets for high-value agricultural products. Smallholders entering contractual relations with buyers of products such as fruit and vegetables, meat or milk often become highly specialized and derive a considerable income 
share from the output sold under contract. However, production contracts remain incomplete if non-visible product quality attributes are observable to the buyer but not to the selling farmer. If buyers behave opportunistically and exploit this asymmetry of information to increase their residual income, output prices for producers are lower than in a situation of symmetric information. Producers taking this into account may underinvest, i.e. use suboptimal levels of input translating into lower output levels, a non-desirable outcome for farmers and buyers.

In this chapter we have shown that third-party contract enforcement can be a useful way to mitigate the adverse effects of asymmetry of information. Conducting a field experiment with dairy farmers we find that the provision of third-party contract enforcement had a positive impact on input use (mainly purchased fodder) and output levels (quantity of milk fat and total solid), ultimately translating into higher household welfare for specific subgroups of the sample. Given the design of our intervention we cannot fully avoid positive contamination of the control group, and thus may even underestimate the treatment effect.

From the available data we infer that the observed treatment effect can be fully attributed to a behavioral change of farmers, instead of a change in the reporting strategy of the company. It can also be concluded that in this specific case, the company had not exploited the informational advantage when the contract was yet incomplete. Instead the company was playing fair but could not credibly signal its type to the dairy producers due to the specific architecture of the supply chain. Hence, it is not only the smallholders benefitting from more transparency regarding quality assessment. If more output per farmer is generated, per-unit transaction cost 
for the buying firm goes down. As both sides in the transaction are better off, the contract enforcement leads to a Pareto improvement.

Cooperating with the leading company in the Vietnamese dairy sector we accessed a representative sample of farmers, producing under a standard contract. Hence, our results were obtained in an environment which is highly representative for the fast growing Vietnamese dairy sector. The trends in the findings of this particular study are also transferable to other agricultural sectors. Of course, the initial trustfulness of the relation between farmer and a contracting company may vary from case to case. However, if non-visible quality attributes determine the output price but testing requires sophisticated and costly laboratory equipment, independent testing will help to overcome the detrimental information asymmetry, be it for fat content of milk, sugar concentration in beets or cane as well as protein content of grains-in Vietnam and beyond. Hence, we suggest that public support to establish infrastructure required for independent quality assessment and verification would be one way to increase farm productivity to the benefit of all stakeholders in agricultural supply chains of developing countries. 


\section{Conclusions}

\subsection{Synopsis}

Over the past two decades, the agrifood industry in developing countries has undergone rapid modernization. Economic growth, rising incomes, urbanization and spread of western lifestyle have led to changing consumption patterns. The demand for high-value agricultural products like fruit and vegetables, milk and meat has increased tremendously. Fresh and high quality produce is en vogue, and meeting consumers' aspirations towards product quality attributes such as size, shape, color and taste but also process quality presents an immense challenge to processors, wholesalers and retailers. As timely supply of high-quality produce becomes a key factor, the degree of control required in the value chain increases. To facilitate supply chain relations, vertical integration is fostered: One widely embraced approach is contract farming. The arrangements between buying firms and selling farmers entail a large variety of oral or written agreements anywhere on the stratum between spot market transactions and full integration as the two extreme cases.

This exciting development in the agricultural sector of many developing countries brings new drive into rural areas which for a long time have merely been seen as a pool of labor for ever growing urban agglomerations. But who are the farmers benefiting from this development? Is it smallholders or larger producers?

If small-scale farmers were included in these emerging markets, the development had a distinct pro-poor dimension as a large share of the rural poor 
engages in farming. Also, benefits could spill over into local communities as farms provide jobs and create demand for local goods and services.

Generally, high-value agricultural products, which are usually labor intensive, would fit well in a smallholder agriculture context where family labor is often abundant. However, to supply emerging markets, relationship-specific investments in knowledge, skills, technology and productive assets are required, because farmers engaging in contractual agreements with buying firms oftentimes have to become highly specialized. The initial investment cost presents a hurdle difficult to take for many smallholders, making larger farmers more likely to sign contracts. Due to scale effects, costs arising from repeated transactions are lower for buying firms when dealing with larger farmers. These two important factors may limit participation of small-scale farmers in emerging high-value markets. Indeed, empirical evidence on inclusion of smallholders is mixed. Buying firms seem to oftentimes prefer contracting larger farmers.

However, in regions where farm sizes are predominantly small, like in Vietnam, procuring processors or wholesalers have to cooperate with smallholders. It has been shown that those small-scale producers participating in high-value markets greatly benefit from a combination of improved access to production technology and input and factor markets as well as more stable income. Hence, an important question is how to better link smallholders to high-value markets, by increasing their attractiveness as partners for buying firms operating in these emerging markets.

With this study we contribute to both the literature on high-value markets and the literature on contract farming. We designed bespoke field experimental approaches to investigate two important aspects of contract farming critical to 
tapping yet unused sources of smallholder productivity. On the one hand, looking into the nuts and bolts of contract design we identified financial incentives to effectively induce production of high quality in a smallholder context. On the other hand, we investigated the effect of more transparency in contracts where farmers' compensation is directly linked to product quality attributes.

The major implications of this study are:

First, we could show that under smallholder conditions financial penalties prove to be an effective tool to steer production decisions of farmers towards generating high quality output, but also highlighted the risks of purely malus-based incentive systems with respect to long-term effects for selling farmers and buying firms.

Second, if output quality affects farmers' compensation, transparency with respect to quality assessment is crucial. Incentives conditioned on output quality are only fully effective if farmers have trust in the system of quality measurement employed by the buyer. We showed that trust towards the buying firm can be raised if an independent third party directly assesses quality or, alternatively, if testing results for value-defining quality attributes can be easily verified by farmers. We have pointed out that as a result of more transparency yet blocked resources of productivity are freed.

Interestingly, we could also demonstrate that under specific circumstances third-party quality assessment or verification not only increases the welfare of farmers but also positively affects the buying firm. If a buying firms plays fair, i.e. does not exploit the private information on quality to accrue quasi-rents but-due to the supply chain architecture-is unable to signal its type ("fair”) to farmers, third 
party enforcement even leads to a Pareto improvement, as the firm would benefit from lower per-unit procurement costs.

Third, as the experiments in this study were carried out in close collaboration with a private-sector company in a developing country setting, which had not been done previously, we also contributed methodologically to the existing body of experimental approaches in economics by pushing the frontier of field experiments further outwards.

\subsection{Policy implications}

We found a significant power differential between large buying firms and small-scale farmers. The atomistic supplier structure is very pronounced in the Vietnamese dairy sector. This is aggravated by the fact that smallholders lack effective producer organizations or farm lobby groups.

Hence, strengthening small-scale farmers' bargaining position is critical to their development. This does not necessarily imply restricting the power of large (monopsonistic) processing companies or wholesalers by issuing anti-trust laws. However, competition between buyers should be encouraged and small-scale farmers should be empowered by supporting them in forming effective producer associations or cooperatives. Along this line, policy makers should promote the installation of bodies for independent quality assessment and dispute settlement to increase transparency and legal security in the value chain. These measures would reduce friction in the market by making contracts more reliable and outcomes more predictable for both selling farmers and buying firms. 


\subsection{Limitations of this study and scope for future research}

The focus of this study was on analyzing impacts of effectively designed financial incentives and higher degrees of transparency in contractual agreements with the aim of identifying ways to foster increased smallholder participation in high-value markets.

We have investigated different types of financial incentives in a fixed-price contract. It would be interesting to use framed field experiments to investigate the performance of further contract types in terms of incentivizing production of high quality but also with respect to acceptance of specific contract forms by farmers, e.g. by testing tournaments with their distinct potential in shifting common production risk from the producer to the buyer.

Conducting a randomized controlled trial we have quantified under natural conditions the productivity and welfare gain when yet incomplete contracts became third-party enforced, i.e. the constraint with respect to information asymmetry was lifted. However, the contact in the experiment was enforced ceteris paribus implying that all other potential constraints remained binding. We could not address restrictions with respect to farmers' set of skills, lack of access to the latest technology or a potential liquidity constraint, making it difficult to buy necessary inputs. This means that a contract design that is optimized with respect to the structure of financial incentives and the transparency of the quality-led compensation may still lead to suboptimal outcomes if other constraints remain binding.

Hence, there is scope for further research, also using experimental approaches, to quantify the effects of lifting other constraints. These effects could be ranked in terms of their magnitude and significance in order to formulate policy 
recommendations on how to advance the smallholder sector most economically given that resources are limited.

The initial high hopes that smallholders could actually be "contracted out of poverty" might have been premature as in fact small-scale farmers are often marginalized. However, effectively linking small-scale farmers in emerging highvalue markets through contract agriculture agreements that are better tailored to fit smallholder characteristics and the environment of less developed countries might be promising. Thus, smallholder-inclusive contract farming can be one way to address rural poverty in Vietnam and elsewhere in the developing world. 


\section{References}

ADB (2008): Key indicators for Asia and the Pacific 2008. Asian Development Bank, Manila, Philippines

Akerlof G. A. (1970): The market for "lemons": Quality uncertainty and the market mechanism. Quarterly Journal of Economics Vol. 84: 488-500

Alexander C., R. E. Goodhue and G. C. Rausser (2007): Do incentives for quality matter? Journal of Agricultural and Applied Economics 39: 1-15

Ashraf N., X. Giné and D. Karlan (2009): Finding missing markets (and a disturbing epilogue): Evidence from an export crop adoption and marketing intervention in Kenya. American Journal of Agricultural Economics 91: 973-990

Balbach J. K. (1998): The effect of ownership on contract structure, costs, and quality: The case of the U.S. beet sugar industry. In: The industrialization of agriculture: Vertical coordination in the U.S. food system. J. S. Royer and R. T. Rogers, eds., pp. 155-184. Ashgate Publishing. Aldershot, UK

Bellemare M. F. (2010): Agricultural extension and imperfect supervision in contract farming: evidence from Madagascar. Agricultural Economics 41: 507-517

Binswanger H. (1980): Attitudes towards risk: Experimental measurement in rural India. American Journal of Agricultural Economics 62: 395-407

Birthal P. S., P. K. Joshi and A. Gulati (2005): Vertical coordination in high-value food commodities: Implications for smallholders. MTID Discussion Paper No. 85. International Food Policy Research Institute, Washington, DC, USA 
Bull C., A. Schotter and K. Weigelt (1987): Tournaments and piece rates: An experimental study. Journal of Political Economy 95: 1-33

CIA (2012): The World Fact Book: Vietnam. https://www.cia.gov/library/ publications/the-world-factbook/geos/vm.html (accessed on 08/11/2012)

Claypool L. L. (1984): Concerns and problems of cheese industry for milk quality and procurement—-today and future. Journal of Dairy Science 67: 2091-2094

Cole S. A., X. Gine, J. Tobacman, P. B. Topalova, R. M. Townsend and J. I. Vickery (2009): Barriers to household risk management: Evidence from India. Harvard Business School Finance Working Paper 09-116. Cambridge, MA, USA

Cungu A., H. Gow, J. F. M. Swinnen and L. Vranken (2008): Investment with weak contract enforcement: evidence from Hungary during transition. European Review of Agricultural Economics 35: 75-91

Dave C., C. C. Eckel, C. A. Johnson and C. Rojas (2010): Eliciting risk preferences: When simple is better? Journal of Risk and Uncertainty 41: 219-243

de Janvry A., E. Sadoulet, R. Murgai (2003): Rural Development and rural policy. In: Handbook of Agricultural Economics Vol. 2 Part A. Gardner B. L. and G. C. Rausser, eds., pp 1593-1658. North-Holland, Amsterdam, The Netherlands

Doward A., J. Kydd, J. Morrison and Ian Urey (2004): A policy agenda for pro-poor agricultural growth. World Development 32: 73-89

Duflo E. (2006): Field experiments in development economics. In: Advances in economics and econometrics. Econometric Society Monographs: Theory and applications, Ninth World Congress, Vol. 2. Blundell R., W. K. Newey and T. Persson, eds., pp 322-348. Cambridge University Press, Cambridge, UK 
Duflo E., M. Kremer, and J. Robinson (2008): How high are rates of return to fertilizer? Evidence from field experiments in Kenya. American Economic Review 98: $482-88$

Duflo E., M. Kremer, and J. Robinson (2011): Nudging farmers to use fertilizer: Theory and experimental evidence from Kenya. American Economic Review 101: $2350-2390$

Eckel C. C., P. J. Grossman (2008): Men, women and risk aversion: Experimental evidence. In: Handbook of Experimental Economics Results, Volume 1. Plott C. R. and V. L. Smith, eds. pp 1061-1076. North-Holland, Amsterdam, The Netherlands Fafchamps M. (2003): Rural poverty, risk and development. Edward Elgar, Cheltenham, UK

FAO (2005): Livestock sector brief: Vietnam. Livestock information, sector analysis and policy branch, AGAL. Food and Agriculture Organization of the United Nations, Rome, Italy

Fuller F., J. Huang, H. Ma and S. Rozelle (2006): Got milk? The rapid rise of China’s dairy sector and its future prospects. Food Policy 31: 201-215

Gächter S. and B. Herrmann (2011): The limits of self-governance when cooperators get punished: Experimental evidence from urban and rural Russia. European Economic Review 55: 193-210

Gale F. and D. Hu (2009): Supply chain issues in China's milk adulteration incident. Paper presented at the IAEA Conference in Beijing, China, August 16-22 Ghatak M. and P. Pandey (2000): Contract choice in agriculture with joint moral hazard in effort and risk. Journal of Development Economics 63: 303-326 
Goodhue R. E., D. M. Heien, H. Lee and D. A. Sumner (2004): Contracts and quality in the California winegrape industry. Review of Industrial Organization 23: 267-282 Goodhue R. E., S. Mohapatra, G. C. Rausser (2010): Interactions between incentive instruments: Contracts and quality in processing tomatoes. American Journal of Agricultural Economics 92: 1283-1293

Gow H. R. and J. F. M. Swinnen (1998): Up- and downstream restructuring, foreign direct investment, and hold-up problems in agricultural transition. European Review of Agricultural Economics 25: 331-350

Gow H. R., D. H. Streeter and J. F. M. Swinnen (2000): How private contract enforcement mechanisms can succeed where public institutions fail: the case of Juhocukor a.s. Agricultural Economics 23: 253-256

Grossmann S. J. (1981): The informational role of guaranties and private disclosure about product quality. Journal of Law and Economics 24: 461-483

Harrison G. W., E. Johnson, M. McInnes, E. E. Rutström (2005): Risk Aversion and incentive effects: Comment. American Economic Review 95: 897-901

Harrison G. W., M. I. Lau and M. B. Williams (2002): Estimating individual discount rates in Denmark: A field experiment. American Economic Review 92: 1606-1617

Harrison G. W. and J. A. List (2004): Field experiments. Journal of Economic Literature 42: 1009-1055

Hazell P., C. Poulton, S. Wiggins and A. Dorward (2010): The future of small farms: Trajectories and policy priorities. World Development 38: 1349-1361 
Hill R. V. and A. Viceisza (2011): A field experiment on the impact of weather shocks and insurance on risky investment. Experimental Economics. DOI: 10.1007/s10683-011-9303-7

Holt C. A. and S. K. Laury (2002): Risk aversion and incentive effects. American Economic Review 92: 1644-55

Hueth B., E. Ligon, S. Wolf and S. Wu (1999): Incentive instruments in fruit and vegetable contracts: Input control, monitoring, measuring, and price Risk. Review of Agricultural Economics 21: 374-389

Ibáñez M. and P. Martinsson (2008): Can we do policy recommendations from a framed field experiments? The case of coca cultivation in Colombia. Working Paper in Economics Series, Department of Economics, University of Gothenburg, Sweden Jaffee S. (1992): Enhancing agricultural growth through diversification in subSaharan Africa. In: Trends in agricultural diversification: Regional perspectives, Technical Paper No. 180. Barghouti S., S. Garbus, D. Umali, eds. The World Bank, Washington, DC, USA

Kachelmeier S. J. and M. Shehata (1992): Examining risk preferences under high monetary incentives: Experimental evidence from the People’s Republic of China. American Economic Review 82: 1120-1141

Key N. and D. Runsten (1999): Contract farming, smallholders, and rural development in Latin America: the organization of agroprocessing firms and the scale of outgrower production. World Development 27: 381-401

Kirsten J. and K. Sartorius (2002): Linking agribusiness and small-scale farmers in developing countries: Is there a new role for contract farming? Development Southern Africa 19: 503-529 
Kremer M., N. Chaudhury, J. Hammer, F. Rogers and K. Muralidharan (2005): Teacher absence in India: A snapshot. Journal of the European Economic Association 3: 658-667

Levitt S. D. and J. A. List (2007): What do laboratory experiments measuring social preferences reveal about the real world? Journal of Economic Perspectives 21: 153174

Levitt S. D. and J. A. List (2009): Field experiments in economics: The past, the present, and the future. European Economic Review 53: 1-18

Lybbert T. J. (2005): Indian farmers' valuation of yield distributions: Will poor farmers value 'pro-poor' seeds? Food Policy 31: 415-441

Maertens M. and J. F. M. Swinnen (2009): Trade, standards and poverty: The case of vegetable exports from Senegal. World Development 37: 161-178

Masakure O. and S. Henson (2005): Why do small-scale producers choose to produce under contract? Lessons from nontraditional vegetable exports from Zimbabwe. World Development 33: 1721-1733

Mergenthaler M., K. Weinberger and M. Qaim (2009): Consumer valuation of food quality and food safety attributes in Vietnam. Review of Agricultural Economics 31: 266-283

Miguel E. and M. Kremer (2004): Worms: Identifying impacts on education and health in the presence of treatment externalities. Econometrica 72: 159-217 Minten B., L. Randrianarison and J. F. M. Swinnen (2009): Global retail chains and poor farmers: Evidence from Madagascar. World Development 37: 1728-1741 
Neven D., M. Odera, T. Reardon and H. Wang (2009): Kenyan supermarkets, emerging middle-class horticultural farmers, and employment impacts on the rural poor. World Development 37: 1802-1811

Pingali P. (2007): Westernization of Asian diets and the transformation of food systems: Implications for research and policy. Food Policy 32: 281-298

Rasmussen E. (2007): Games and information: an introduction to game theory - 4th ed. Blackwell, Malden, MA, USA

Rao E. J. O., B. Brümmer and M. Qaim (2011): Farmer participation in supermarket channels, production technology, and efficiency: The case of vegetables in Kenya. Global Food Discussion Paper No. 6. University of Goettingen. http://ageconsearch.umn.edu/bitstream/113508/2/GlobalFood_DP6.pdf. (accessed on $03 / 22 / 2012)$

Reardon T., C. B. Barrett, J.A. Berdegué and J.F.M. Swinnen (2009): Agrifood industry transformation and small farmers in developing countries. World Development 37: 1717-1727

Ross S. A. (1973): The economic theory of agency: The principal's problem. American Economic Review 63: 134-139

Roth F. X., F. J. Schwarz and G. I. Stangl (2011): Tierernährung. DLG-Verlag, Frankfurt am Main, Germany

Rothschild M. and J. Stiglitz (1976): Equilibrium in competitive insurance markets: As essay in the economics of imperfect information. Quarterly Journal of Economics 90: 629-650

Royer A. (2011): Transaction costs in milk marketing: A comparison between Canada and Great Britain. Agricultural Economics 42: 171-182 
Sandmo A. (1971): On the theory of the competitive firm under price uncertainty. American Economic Review 61: 65-73

Schipmann C. and M. Qaim (2010): Spillovers from modern supply chains to traditional markets: product innovation and adoption by smallholders. Agricultural Economics 41: 361-371

Schipmann C. and M. Qaim (2011): Supply chain differentiation, contract agriculture, and farmers' marketing preferences: The case of sweet pepper in Thailand. Food Policy 36: 666-676

Skoufias E. (2001): PROGRESA and its impact on the welfare of rural households in Mexico. IFPRI Research Report 139. International Food Policy Research Institute, Washington, DC, USA

Spence M. (1973): Job market signaling. The Quarterly Journal of Economics 87: 355-374

Stiglitz J. and A. Weiss (1981): Credit rationing in markets with imperfect information. American Economic Review 71: 393-410.

Swinnen J. F. M. (2009): Reforms, globalization, and endogenous agricultural structures. Agricultural Economics 40: 719-732

Swinnen J. F. M. and A. Vandeplas (2010): Market power and rents in global supply chains. Agricultural Economics 41: 109-120

Sykuta M. E., M. L. Cook (2001): A new institutional economics approach to contracts and cooperatives. American Journal of Agricultural Economics 83: 12731279 
Tanaka T., C. F. Camerer and Q. Nguyen (2010): Risk and time preferences: Linking experimental and household survey data from Vietnam. American Economic Review 100: $557-571$

Thomas D., E. Frankenberg, J. Friedman, J. P. Habicht and E. Al (2003): Iron deficiency and the well being of older adults: Early results from a randomized nutrition intervention. Working Paper, University of California, Los Angeles. http://emlab.berkeley.edu/users/webfac/emiguel/e271_s04/friedman.pdf (accessed on 04/14/2010)

Throsby D. (1994): The production and consumption of the arts: A view of cultural economics. Journal of Economic Literature 32: 1-29

USDA (2011): Colossal growth in the Vietnamese dairy industry. GAIN Report. United States Department of Agriculture, Foreign Agricultural Service, Washington, DC, USA. http://www.globaltrade.net/f/market-research/pdf/Vietnam/Processing-ofFood-and-Agricultural-Products-Colossal-Growth-in-the-Dairy-Industry.html (accessed on 01/30/2012)

Vukina T. and P. Leegomonchai (2006): Oligopsony power, asset specifity, and hold-up: Evidence from the broiler industry. American Journal of Agricultural Economics 88: 589-605

Wiggins S., J. Kirsten and L. Llambí (2010): The future of small farms. World Development 38: 1341-1348

Williamson O. E. (1979): Transaction-cost economics: The governance of contractual relations. The Journal of Law and Economics 22: 233-261

Weinberger K. and T. A. Lumpkin (2007): Diversification into horticulture and poverty reduction: a research agenda. World Development 35: 1464-1480 
Wollni M. and M. Zeller (2007): Do farmers benefit from participating in specialty markets and cooperatives. The case of coffee marketing in Costa Rica. Agricultural Economics 37: 243-248

World Bank (2007): World Development Report 2008: Agriculture for development. The World Bank, Washington, DC, USA

Wu S. Y. and B. Roe (2005): Behavioral and welfare effects of tournaments and fixed performance contracts: Some experimental evidence. American Journal of Agricultural Economics 87: 130-146

Wu S. Y. and B. Roe (2007): Contract enforcement, social efficiency, and distribution: Some experimental evidence. American Journal of Agricultural Economics 89: 243-258

Young L. M. and J. E. Hobbs (2002): Vertical linkages in agri-food supply chains: changing roles for producers, commodity groups, and government policy. Review of Agricultural Economics 24: 428-441 


\section{Appendix A: Additional tables}

A 1: Summary statistics of selected variables and pair-wise comparisons by milk collection center (MCC)

\begin{tabular}{|c|c|c|c|c|}
\hline & \multicolumn{4}{|c|}{ Mean (SD in parentheses) } \\
\hline & $\begin{array}{l}\text { MCC A } \\
(n=113)\end{array}$ & $\begin{array}{l}\text { МСС B } \\
n=(103)\end{array}$ & $\begin{array}{l}\text { MCC C } \\
(n=86)\end{array}$ & $\begin{array}{l}\text { MCC D } \\
n=(83)\end{array}$ \\
\hline \multicolumn{5}{|l|}{$\underline{\mathrm{HH}-c h a r a c t e r i s t i c s}$} \\
\hline \multirow[t]{2}{*}{ No. of HH member } & 4.513 & 4.641 & 4.244 & 4.341 \\
\hline & [1.536] & [1.514] & [1.255] & [1.399] \\
\hline \multirow[t]{2}{*}{ Age of HH-head } & 45.46 & 44.66 & 47.61 & 47.38 \\
\hline & [11.53] & [9.161] & [11.74] & [11.39] \\
\hline \multirow[t]{2}{*}{ Total HH income (VND) } & $74,192,179$ & $82,514,741$ & $67,618,558$ & $73,970,047$ \\
\hline & {$[49,567,765]$} & {$[69,491,153]$} & {$[58,362,681]$} & {$[53,442,489]$} \\
\hline \multirow[t]{2}{*}{ Dairy income (VND) } & $45,968,059$ & $53,551,420$ & $44,313,419$ & $52,171,927$ \\
\hline & {$[35,675,422]$} & {$[55,525,486]$} & {$[53,633,181]$} & {$[47,796,603]$} \\
\hline \multicolumn{5}{|l|}{ Dairy production } \\
\hline \multirow[t]{2}{*}{ Herd size (heads) } & 7.611 & 8.194 & 7.744 & 6.398 \\
\hline & [5.417] & [5.369] & [4.587] & [3.751] \\
\hline \multirow[t]{2}{*}{ Productivity per Cow (kg) } & $4,051.6$ & $4,925.9 *$ & $4,477.3$ & n.a. \\
\hline & {$[2,888.4]$} & {$[2,229.7]$} & {$[2,472.7]$} & \\
\hline \multirow[t]{2}{*}{ Average milk price (VND) } & $6,850.0$ & $6,730.9 * *$ & $6,542.4 * * *$ & $6,671.4^{*}$ \\
\hline & {$[275.6]$} & [294.7] & [416.7] & [772.3] \\
\hline \multirow[t]{2}{*}{ Total solid (\%) } & 12.63 & 12.50 & $12.35^{* * *}$ & 12.61 \\
\hline & {$[0.520]$} & {$[0.496]$} & {$[0.427]$} & [0.641] \\
\hline \multirow[t]{2}{*}{ Milk fat (\%) } & 3.980 & $3.907 *$ & $3.862 * *$ & 4.074 \\
\hline & {$[0.280]$} & [0.245] & {$[0.221]$} & {$[0.482]$} \\
\hline \multirow[t]{2}{*}{ Milk hygiene score } & 3.572 & 3.642 & $3.686 * *$ & 3.578 \\
\hline & [0.368] & [0.205] & [0.162] & [0.465] \\
\hline
\end{tabular}

Mean differences are tested for MCC B - MCC A, MCC C - MCC A and MCC D - MCC C. Asterisks indicate statistically significant mean differences. Levels for mean differences: $* * * p<0.01, * * p<0.05, * p<0.10$. 


\section{Appendix B: Survey questionnaire ${ }^{12}$}

\section{GENERAL INFORMATION:}

\section{Location}

GPS coordinates:

N Latitude:

E Longitude:

Date of the interview (DD/MM):

Name of the interviewee:

Interviewee the same as in the $1^{\text {st }}$ follow-up survey $\square$ Yes

$\square$ No

Name of the decision-maker (if different from interviewee):

Have you been delivering milk to Vinamilk MCC? $\square$ Yes

$\square$ No

If not, what are the reasons for not delivering: $\square$ Lack of labor $\square$ Ineffective $\square$ risky $\square$ change to other job $\square$ move to other milk company $\square$ other

Ifyou deliver milk to company other than VNM, please state the reasons? $\quad \square$ Higher price

$\square$ Closer to my farmstead Other (specify)

Current MILK delivering ID:

Is it your own ID or somebody else's ID?

$$
\square \text { My own } \quad \square \text { Somebody else's }
$$

Is it the same ID with that in September/October 2010 (when we conducted our $2^{\text {nd }}$ survey)?

Yes $\quad \square$ No

If No, name the VINAMILK ID (s) under which you previously delivered

ID 1

ID 2

Do you accept milk from other farmers and deliver it together with your own milk under your Vinamilk ID? $\quad \square$ Yes $\quad \square$ No

\section{Contact:}

Village commune district province

Landline phone number: Mobile phone number:

\footnotetext{
${ }^{12}$ The survey instrument shown here was used for the $2^{\text {nd }}$ follow-up survey. The questionnaire employed in the baseline survey and first follow-up were structured similarly.
} 
MODULE: INFORMATION ON HOUSEHOLD MEMBERS

\begin{tabular}{|l|ll|c|l|l|l|l}
\hline HH1 & $\begin{array}{l}\text { How many individuals compose this } \\
\text { household? }\end{array}$ & a. & $\begin{array}{l}\text { Enumerator: In the Table below, there should be as many lines filled as the } \\
\text { household size indicated by the response to question HH1. Start with the household } \\
\text { head! }\end{array}$
\end{tabular}

\begin{tabular}{|c|c|c|c|c|c|c|c|c|c|c|c|}
\hline \multirow[t]{2}{*}{ PID } & \multirow[t]{2}{*}{$\begin{array}{l}\text { Name of } \\
\text { household } \\
\text { member }\end{array}$} & \multirow[t]{2}{*}{$\begin{array}{l}\text { Relation- } \\
\text { ship with } \\
\text { head of } \\
\text { household }\end{array}$} & \multirow[t]{2}{*}{$\begin{array}{l}\text { Relation- } \\
\text { ship } \\
\text { Code* }\end{array}$} & \multirow[t]{2}{*}{$\begin{array}{l}\text { Age } \\
\text { (in } \\
\text { years) }\end{array}$} & \multirow[t]{2}{*}{$\begin{array}{l}\text { Sex } \\
\begin{array}{l}{[1]=M} \\
{[2]=F}\end{array}\end{array}$} & \multirow[t]{2}{*}{$\begin{array}{l}\text { Education } \\
\text { (highest grade } \\
\text { obtained) }\end{array}$} & \multirow[t]{2}{*}{$\begin{array}{c}\text { Edu } \\
\text { Code } \\
* *\end{array}$} & \multicolumn{2}{|c|}{$\begin{array}{c}\text { Main occupation } \\
\text { (enter }-7 \text { for children under } 5 \\
\text { Enter -8 if no occupation) }\end{array}$} & \multicolumn{2}{|c|}{$\begin{array}{c}\text { Second occupation } \\
\text { (enter -7 for children under } \\
\text { 5) } \\
\text { (If no secondary } \\
\text { occupation, enter code 27) }\end{array}$} \\
\hline & & & & & & & & Description & $\begin{array}{l}\text { Code } \\
* * *\end{array}$ & Description & Code \\
\hline 01 & & & & & & & & & & & \\
\hline 02 & & & & & & & & & & & \\
\hline 03 & & & & & & & & & & & \\
\hline 04 & & & & & & & & & & & \\
\hline 05 & & & & & & & & & & & \\
\hline 06 & & & & & & & & & & & \\
\hline 07 & & & & & & & & & & & \\
\hline 08 & & & & & & & & & & & \\
\hline 09 & & & & & & & & & & & \\
\hline 10 & & & & & & & & & & & \\
\hline
\end{tabular}

* 1: Household head; 2: spouse; 3: children; 4: other household member; 5: non-family members.

** 1: illiteracy/incomplete primary; 2: complete primary; 3: complete lower secondary; 4: complete upper secondary; 5: college/university; 6: other

*** 1: self farm; 2: hired farm; 3: self managed non-farm /trader; 4: retired; 5: government officers; 6: student; 7: children under 6; 8: not woking; 27: no second occupation. 
MODULE: HOUSEHOLD MEMBERS’ INCOME GENERATION ACTIVITIES

This Section aims to measure labor allocation for income generating activities in the household (not cooking, childcare, etc.). The activities reported should include any activities from which the household derives part of its income. This may include agricultural work on the household's agricultural farm, off-farm agricultural activities, small business (handicraft, etc...), hired labor etc...

Enumerator: One household member may perform several different activities during the year. Please report ALL OF THEM, using ONE LINE FOR EACH ACTIVITY.

\begin{tabular}{|c|c|c|c|c|}
\hline$\#$ & Name of activity & Code * & $\begin{array}{c}\text { Annual income generated by } \\
\text { this activity }\end{array}$ & $\begin{array}{c}\text { Share that the activity } \\
\text { contributes to total household } \\
\text { income (in percent) }\end{array}$ \\
\hline 1 & & & & \\
\hline 2 & & & & \\
\hline 3 & & & & \\
\hline 4 & & & & \\
\hline 5 & & & & \\
\hline 6 & & & & \\
\hline 7 & & & & \\
\hline 8 & & & & \\
\hline 9 & & & & \\
\hline
\end{tabular}

*: 1: self managed farm; 2: hired farm; 3: self-managed non-farm (constructor, mason, carpenter, trader, handicraft, etc.); 4: hired non-farm (mason, carpenter, worker, cashier, etc.); 5: pension; 6: government salary; 7: other.

Remittances, Charity transfers from government (subsidy program), Pensions and Donations (e.g. from NGO)

Did the household receive money or donations from family members who left the household to work in a different area/city/abroad? $\square$ Yes

If yes, pls quantify the remittances you have received over the last 12 months VND

Other sources of income over the last 12 months (transfers, etc.) VND 


\section{MODULE: CREDIT}

Have you tried to get a loan (cash or in-kind) during the last 5 years? $\square$ Yes $\square$ No If no,
Was it because you could but did not want it?
$\square$ Yes
$\square$ No
Was it because you thought that you would not get it?
$\square$ Yes
$\square$ No

Please give details about the five main loans (NO in-kind loans for fodder provided by the MCC). Include those you have paid back, as well as loans you have not paid back as yet. Please start with the biggest loan

\begin{tabular}{|c|c|c|c|c|c|c|c|c|c|c|c|}
\hline $\begin{array}{c}\text { Loan } \\
\text { number } \\
\text { LID }\end{array}$ & $\begin{array}{c}\text { Loan } \\
\text { amount } \\
\text { (VND’000) }\end{array}$ & $\begin{array}{l}\text { Source } \\
\text { of loan }\end{array}$ & $\begin{array}{l}\text { Source } \\
\text { code } *\end{array}$ & $\begin{array}{c}\text { When } \\
\text { did you } \\
\text { borrow? } \\
\text { (Year) }\end{array}$ & $\begin{array}{c}\begin{array}{c}\text { Loan } \\
\text { term }\end{array} \\
\text { (month) } \\
\text { put } 99 \text { if } \\
\text { no term } \\
\text { is } \\
\text { indicated }\end{array}$ & $\begin{array}{c}\text { Monthly } \\
\text { interest } \\
\text { rate? }\end{array}$ & $\begin{array}{c}\text { Loan } \\
\text { purpose? }\end{array}$ & $\begin{array}{l}\text { Purpose } \\
\text { code ** }\end{array}$ & $\begin{array}{c}\text { Quantity of } \\
\text { outstanding } \\
\text { loan } \\
\text { (VND’000) }\end{array}$ & $\begin{array}{l}\text { What } \\
\text { type of } \\
\text { collateral } \\
\text { did you } \\
\text { give? }\end{array}$ & $\begin{array}{c}\text { Code of } \\
\text { collateral } \\
* * *\end{array}$ \\
\hline 1 & & & & & & & & & & & \\
\hline 2 & & & & & & & & & & & \\
\hline 3 & & & & & & & & & & & \\
\hline 4 & & & & & & & & & & & \\
\hline 5 & & & & & & & & & & & \\
\hline
\end{tabular}

* 1: bank; 2: private money lender; 3: relatives; 4: friends/neighbour; 5: coop; 6: NGOs; 7: other organizations.

** 1: input for cultivation; 2: input for livestock; 3: investment on breeding; 4: non-farm investment; 5: other.

*** 1: Red/pink book (land use certificate/house/property certificate); 2: Deposit (saving account); 3: gold; 4: pension book; 5: group guaranty; 6: other.

Does the milk collection center in-kind provide you feed (i.e. concentrate, cassava residues, beer residues) of a certain value that is then deducted from future payments of milk? $\quad \square$ Yes $\quad \square$ No

Did you obtain in-kind provision of production inputs (seedlings, fertilizer, pesticides, etc.) from input traders/shops?

$\square$ Yes $\quad \square$ No 


\section{MODULE: LAND, LAND USE}

How many different parcels does the household control (incl. home garden)?

Enumerator: the total number of parcels should include (i) the land that the household owns (has title upon) and uses itself (for production, housing or others), (ii) the land that the household does not own but rents/borrows/sharecrops in, and (iii) the land that the household owns but rents/lends/sharecrops out.

\begin{tabular}{|c|c|c|c|c|c|c|c|c|c|c|c|c|c|}
\hline \multirow[t]{2}{*}{ LID } & \multirow[t]{2}{*}{$\begin{array}{l}\text { Walking } \\
\text { time from } \\
\text { residence* }\end{array}$} & \multirow{2}{*}{$\begin{array}{l}\text { Type } \\
\text { of } \\
\text { land } \\
\text { by } \\
\text { Main } \\
\text { use** }\end{array}$} & \multirow[t]{2}{*}{$\begin{array}{c}\text { Physical } \\
\text { Parcel } \\
\text { Size } \\
\left(\text { in } \mathrm{m}^{2}\right)\end{array}$} & \multirow[t]{2}{*}{$\begin{array}{c}\text { Type of } \\
\text { land by } \\
\text { ownership } \\
* * *\end{array}$} & \multirow{2}{*}{$\begin{array}{l}\text { If rented } \\
\text { in/out, } \\
\text { indicate } \\
\text { annual } \\
\text { renting } \\
\text { value } \\
\text { (VND’000) }\end{array}$} & \multicolumn{4}{|c|}{$\begin{array}{l}\text { If crop land, main } 2 \text { crops cultivated on this plot } \\
\text { last } 12 \text { months (sequential cropping) }\end{array}$} & \multicolumn{4}{|c|}{$\begin{array}{l}\text { If crop land, main } 2 \text { crops cultivated on } \\
\text { this plot simultaneously (Intercropping) }\end{array}$} \\
\hline & & & & & & Crop & Cod & Crop & Cod & Crop & $\mathrm{C}$ & Crop & $\mathrm{C}$ \\
\hline 01 & & & & & & & & & & & & & \\
\hline 02 & & & & & & & & & & & & & \\
\hline 03 & & & & & & & & & & & & & \\
\hline 04 & & & & & & & & & & & & & \\
\hline 05 & & & & & & & & & & & & & \\
\hline
\end{tabular}

* 1 = adjacent; 2 = within 5 min; 3 = within 15 min; 4 = within 1 hour; 5 = within 2 hours; 6 = more than 2 hours

** 1 = home garden; 2 = cultivated crop; 3 = pasture/grassland; 4 = fallow; 5 = fish pond; 6 = unusable; 7 : other

*** 1 = inherited; 2 = rented-in; $3=$ rented out, $4=$ share-cropped in, $5=$ share-cropped out, $6=$ borrowed free of charge; $7=$ buy; $8:$ other. 


\section{AGRICULTURAL YIELDS, CROP INCOME}

Please indicate the yield in ton/cong $\left(1000 \mathrm{~kg} / 1000 \mathrm{~m}^{2}\right)$ from pasture/grassland (if applicable) by grass variety (if applicable) and season:

\begin{tabular}{|l|l|l|l|}
\hline & Type of Grass & $\begin{array}{c}\text { Rainy season } \\
(1000 \mathrm{~kg} / 1000 \mathrm{~m} 2)\end{array}$ & $\begin{array}{c}\text { Dry season } \\
(1000 \mathrm{~kg} / 1000 \mathrm{~m} 2)\end{array}$ \\
\hline 1 & Elephant & & \\
\hline 2 & Honey & & \\
\hline 3 & Water corn & & \\
\hline 4 & Water elephant & & \\
\hline 5 & Long tay & & \\
\hline 6 & Other: & & \\
\hline
\end{tabular}

Please indicate the yield from rice production (if applicable) for the last 12 months, disaggregated by main product and by-product:

\begin{tabular}{|l|l|l|l|l|l|l|}
\hline Product & $1^{\text {st }}$ harvest & $2^{\text {nd }}$ harvest & $3^{\text {rd }}$ harvest & Total quantity & $\begin{array}{l}\text { Unit value } \\
\text { at the time } \\
\text { of survey } \\
\text { (VND'000) }\end{array}$ & $\begin{array}{l}\text { Total value } \\
\text { (1000 VND) }\end{array}$ \\
\hline $\begin{array}{l}\text { Paddy } \\
\text { (in tons) }\end{array}$ & & & & & & \\
\hline $\begin{array}{l}\text { Rice straw } \\
\text { (in cong or } \\
1000 \mathrm{~m} 2 \text { ) }\end{array}$ & & & & & & \\
\hline
\end{tabular}


Please indicate the following information for each crop other than pasture/grassland/rice mentioned above:

\begin{tabular}{|c|c|c|c|c|c|}
\hline Crop name & $\begin{array}{l}\text { Crop } \\
\text { code }\end{array}$ & $\begin{array}{c}\text { Total } \\
\text { quantity of } \\
\text { crop produced } \\
\text { last } 12 \\
\text { months } \\
\text { (in kg) }\end{array}$ & $\begin{array}{c}\text { Own } \\
\text { consumption } \\
\text { over the last } 12 \\
\text { months (for } \\
\text { human being } \\
\text { and farm } \\
\text { animals) } \\
\text { (in kg) }\end{array}$ & $\begin{array}{l}\text { Value of own } \\
\text { consumption at } \\
\text { market price over } \\
\text { the last } 12 \text { months } \\
\text { (for human being } \\
\text { and farm animals) } \\
\text { ('000 VND) }\end{array}$ & $\begin{array}{l}\text { Total amount of } \\
\text { cash received for } \\
\text { crop sold, over } \\
\text { the last } 12 \\
\text { months } \\
\text { ('000 VND) }\end{array}$ \\
\hline & & & & & \\
\hline & & & & & \\
\hline & & & & & \\
\hline & & & & & \\
\hline & & & & & \\
\hline & & & & & \\
\hline & & & & & \\
\hline
\end{tabular}




\section{INPUTS AND EXPENSES IN CROP PRODUCTION}

Please report the expenses that you incurred in CROP ENTERPRISES (incl. rice, fruits, vegetables and pasture/grassland) over the last 12 months

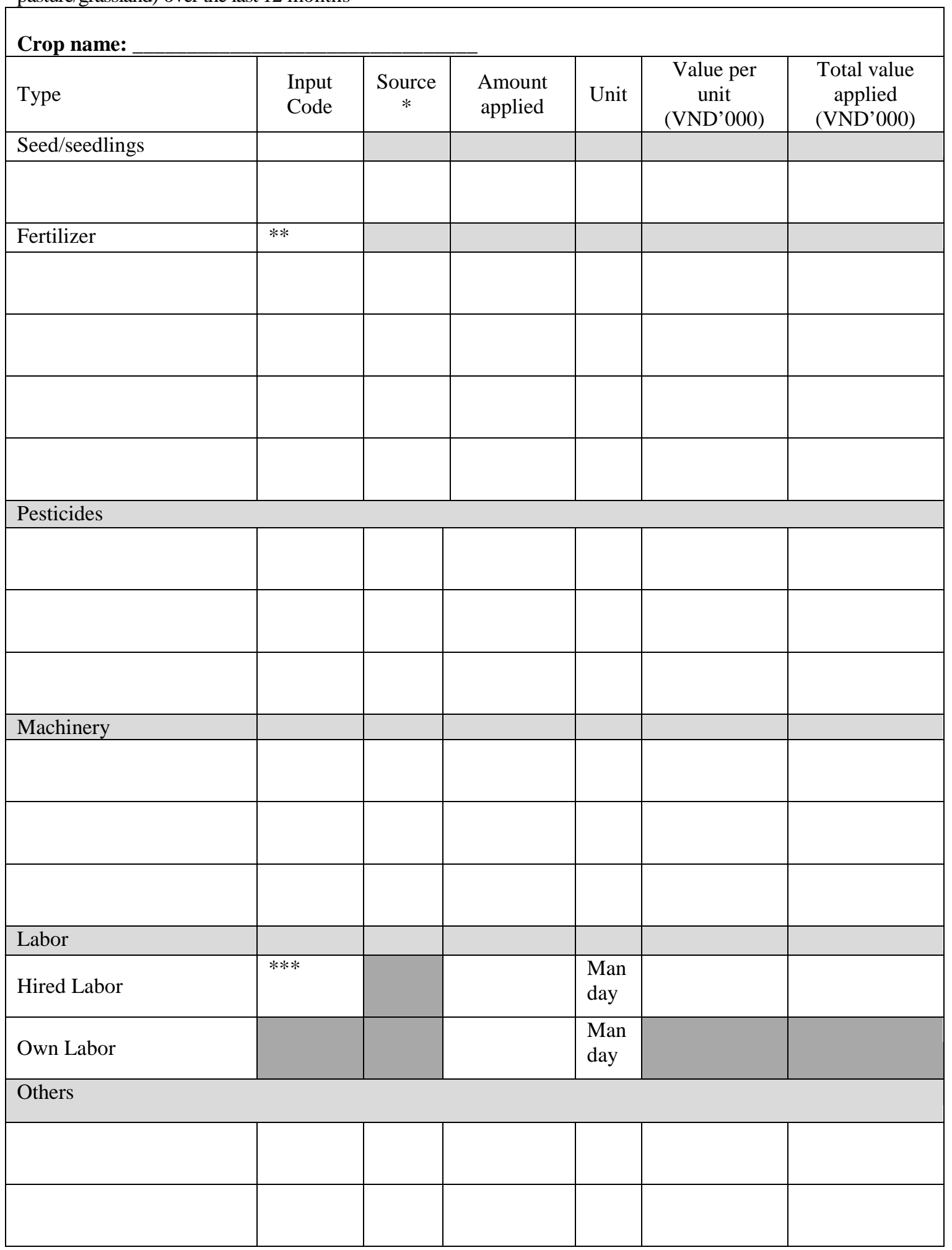

* 1= home produced; 2 = purchased at shop

** $1=$ chemical; $2=$ organic;

$* * * 1$ = permanently hired; 2 = temporarily hired 
Please report the expenses that you incurred in CROP ENTERPRISES (incl. rice, fruits, vegetables and pasture/grassland) over the last 12 months

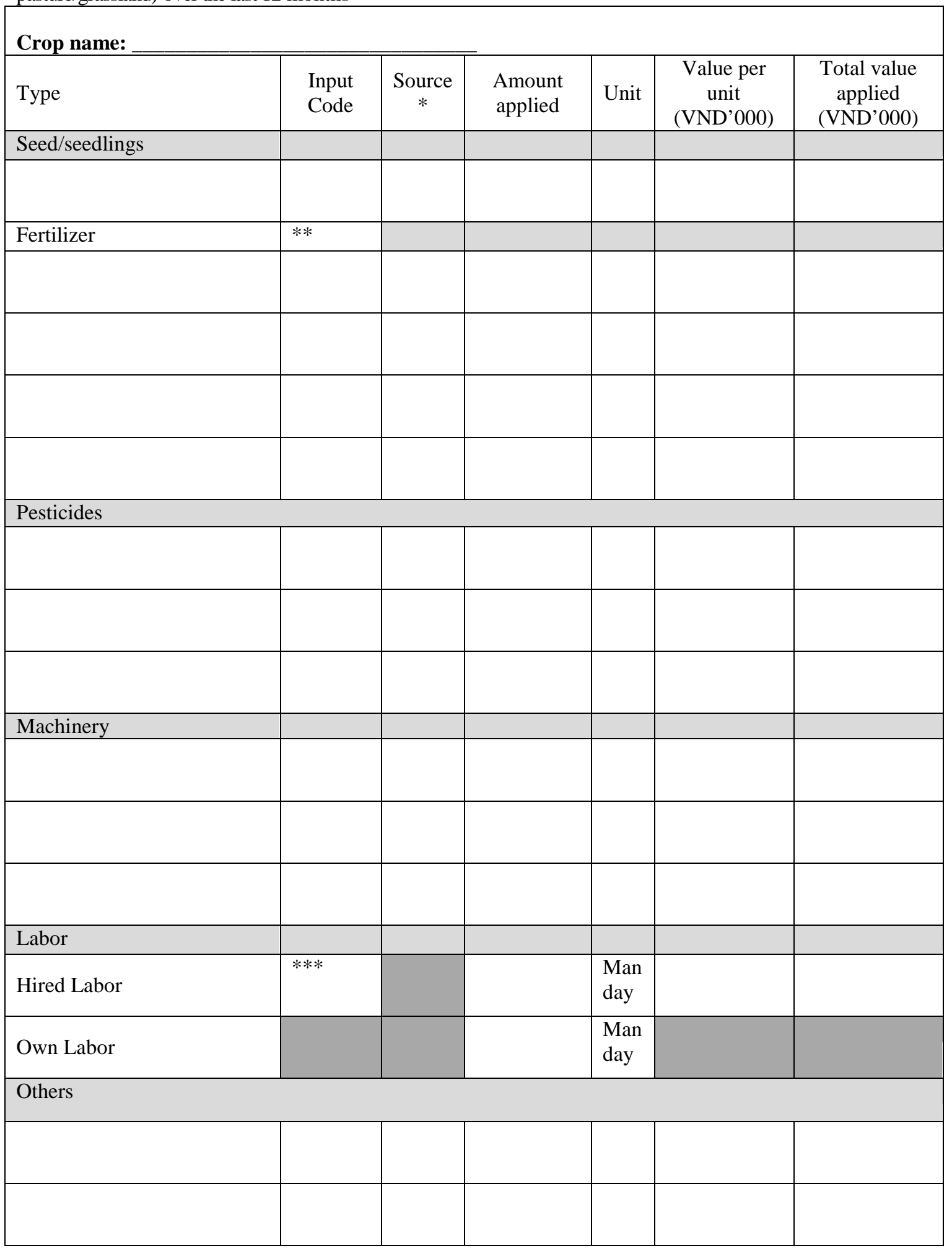

* $1=$ home produced; 2 = purchased at shop

** $1=$ chemical; $2=$ organic;

$* * * 1$ = permanently hired; 2 = temporarily hired 
Please report the expenses that you incurred in CROP ENTERPRISES (incl. rice, fruits, vegetables and pasture/grassland) over the last 12 months

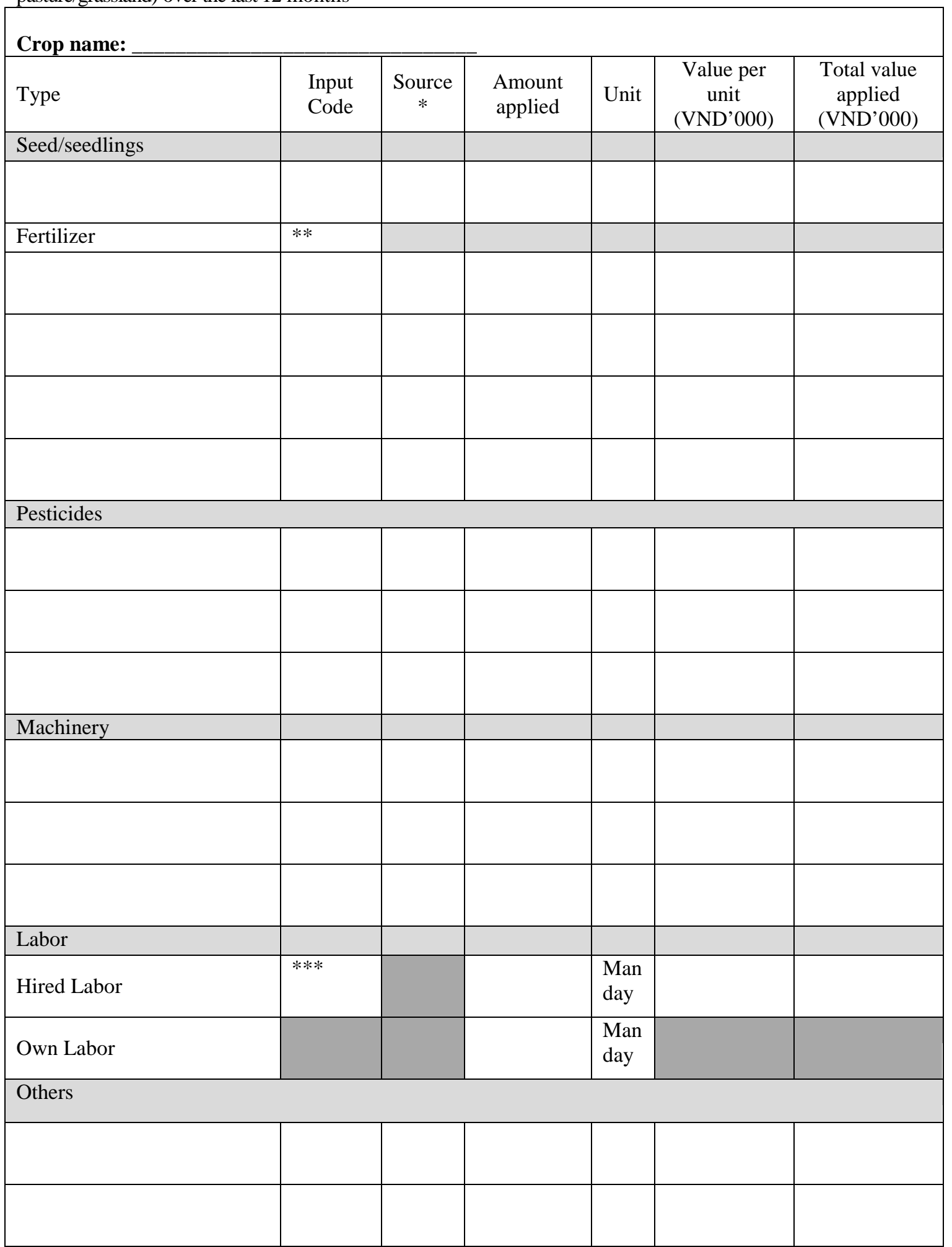

* $1=$ home produced; 2 = purchased at shop

** $1=$ chemical; $2=$ organic;

$* * * 1$ = permanently hired; 2 = temporarily hired 
Please report the expenses that you incurred in CROP ENTERPRISES (incl. rice, fruits, vegetables and pasture/grassland) over the last 12 months

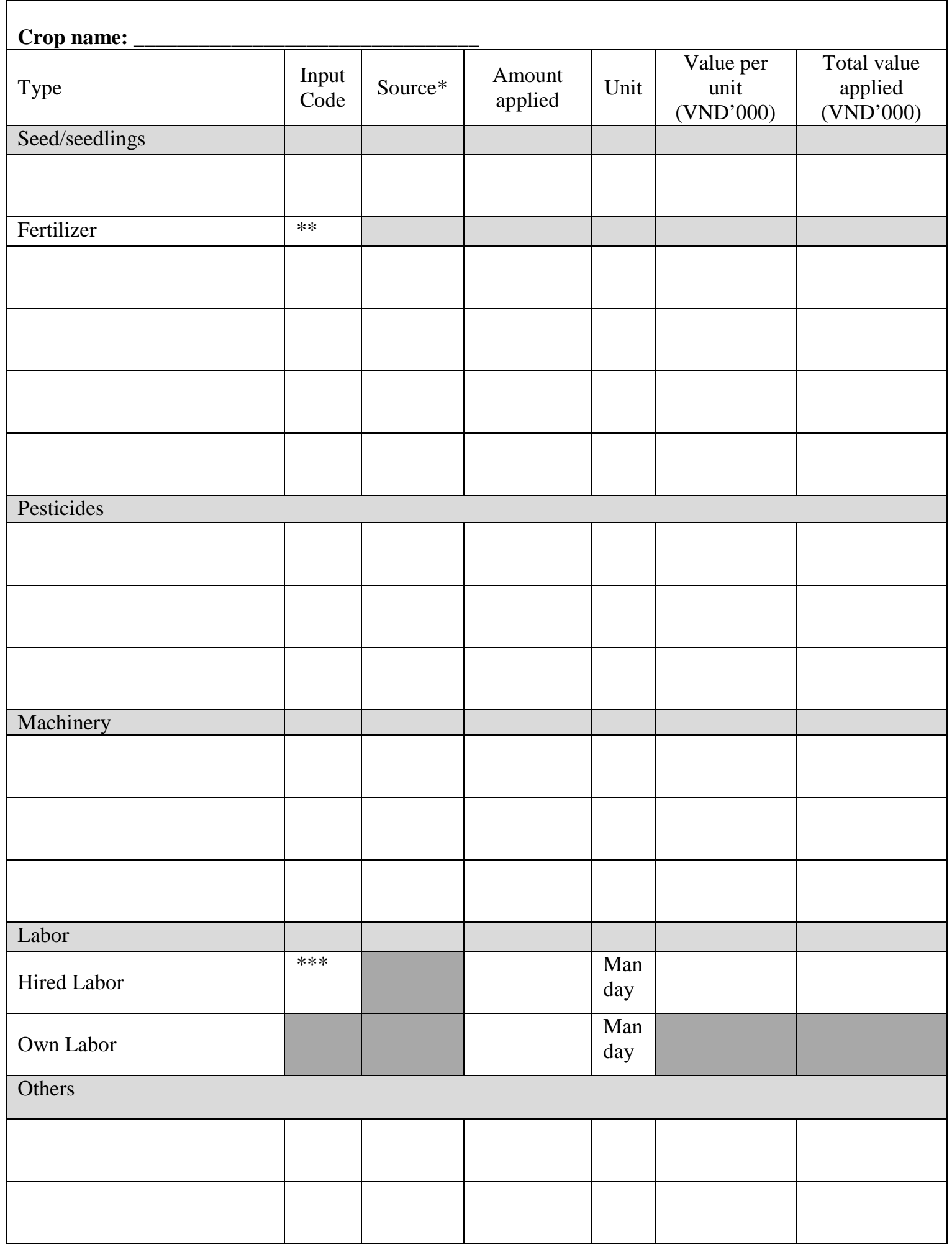

* 1= home produced; 2 = purchased at shop;

** $1=$ chemical; $2=$ organic;

$* * * 1$ = permanently hired; 2 = temporarily hired. 
STOCK, PRODUCTION AND UTILIZATION OF NON-DAIRY LIVESTOCK PRODUCE

Please list the livestock (including fish if applicable) and related output (WITHOUT main- and byproducts from dairy!) by animal variety for the last 12 month.

\begin{tabular}{|l|l|l|l|l|l|l|}
\hline$\#$ & Type of livestock & Unit & $\begin{array}{c}\text { Quantity } \\
\text { produced }\end{array}$ & $\begin{array}{c}\text { Quantity } \\
\text { consumed }\end{array}$ & $\begin{array}{c}\text { Quantity } \\
\text { sold }\end{array}$ & $\begin{array}{c}\text { Total sold value } \\
\text { (VND’00) }\end{array}$ \\
\hline 1 & Sow & & & & & \\
\hline 2 & Fattening pig & & & & & \\
\hline 3 & Chicken & & & & & \\
\hline 4 & Duck & & & & & \\
\hline 5 & Buffalo & & & & & \\
\hline 6 & Non-dairy cattle & & & & & \\
\hline 7 & Fish & & & & & \\
\hline 8 & Pigeon & & & & & \\
\hline 9
\end{tabular}

PRODUCTION AND UTILIZATION OF BY-PRODUCTS FROM NON-DAIRY LIVESTOCK

Please list the livestock BY-PRODUCTS (including fish if applicable) and related output (WITHOUT main- and by-products from dairy!) by animal variety for the last 12 month.

\begin{tabular}{|l|l|l|l|l|l|l|}
\hline$\#$ & \multicolumn{1}{|c|}{$\begin{array}{c}\text { Type of by- } \\
\text { products }\end{array}$} & Unit & $\begin{array}{c}\text { Quantity } \\
\text { produced }\end{array}$ & $\begin{array}{c}\text { Quantity } \\
\text { consumed }\end{array}$ & $\begin{array}{c}\text { Quantity } \\
\text { sold }\end{array}$ & $\begin{array}{c}\text { Total sold value } \\
\text { (VND'000) }\end{array}$ \\
\hline 1 & Manure & & & & & \\
\hline 2 & Egg & & & & & \\
\hline 3 & Other & & & & & \\
\hline 4 & Other & & & & & \\
\hline
\end{tabular}




\section{INPUTS AND EXPENSES IN LIVESTOCK PRODUCTION OTHER THAN DAIRY}

Please list all input expenses that you incurred on LIVESTOCK ACTIVITIES (OTHER THAN DAIRY) over the last 12 months (Value is the most important)

\begin{tabular}{|c|c|c|c|c|c|c|c|}
\hline \# & Input type (specify) & $\begin{array}{l}\text { Input } \\
\text { source* }\end{array}$ & $\begin{array}{l}\text { Frequency } \\
\text { used** }\end{array}$ & $\begin{array}{l}\text { Qty } \\
\text { used } \\
\text { each } \\
\text { time }\end{array}$ & Units & $\begin{array}{l}\text { Unit value } \\
\text { (VND’000) }\end{array}$ & $\begin{array}{c}\text { Total } \\
\text { expense } \\
\text { (VND’000) }\end{array}$ \\
\hline 1 & Grass & & & & & & \\
\hline 2 & Rice Straw & & & & & & \\
\hline 3 & Concentrate & & & & & & \\
\hline 4 & Minerals & & & & & & \\
\hline 5 & Disease medicines & & & & & & \\
\hline 6 & Tonic supplements & & & & & & \\
\hline 7 & Vaccines & & & & & & \\
\hline 8 & Breed (poultry) & & & & & & \\
\hline 9 & Breed (cattle) & & & & & & \\
\hline 10 & Breed (pig) & & & & & & \\
\hline 11 & Breed (other stock) & & & & & & \\
\hline 12 & Insemination & & & & & & \\
\hline 13 & Shed maintenance & & & & & & \\
\hline 14 & Other & & & & & & \\
\hline 15 & Other & & & & & & \\
\hline
\end{tabular}

1=home produced, 2 =purchased

** 1 = per day; 2 = per week; 3 = per month; 4 = per year 


\section{DAIRY PRODUCTION}

\section{Details of The Dairy Herd and Milk Production (I)}

Please list the details for your current dairy herd and disaggregate by cow (incl. heifers, calves, bulls calving and lactation data for cows only if applicable):

\begin{tabular}{|c|c|c|c|c|c|c|c|c|}
\hline & \multirow[t]{2}{*}{$\begin{array}{l}\text { Eartag-ID } \\
\text { (if } \\
\text { applicable) }\end{array}$} & \multirow{2}{*}{$\begin{array}{l}\text { Cattle } \\
{[1]=\text { Cow }} \\
{[2]=\text { Heifer }} \\
{[3]=\text { Bull }} \\
{[4] \quad=} \\
\text { female calf } \\
{[5]=\text { male }} \\
\text { calf }\end{array}$} & \multirow{2}{*}{$\begin{array}{l}\text { Race } \\
{[1]=\text { HO }} \\
{[2]=} \\
\text { HO*Local } \\
{[3]} \\
=\text { CrossSIND }\end{array}$} & \multirow{2}{*}{$\begin{array}{l}\text { Age (in } \\
\text { months) }\end{array}$} & \multirow{2}{*}{$\begin{array}{l}\text { Number of } \\
\text { lactations/ } \\
\text { Number of } \\
\text { calves } \\
\text { born (if } \\
\text { applicable) }\end{array}$} & \multirow{2}{*}{$\begin{array}{c}\text { Cow } \\
\text { currently } \\
\text { in } \\
\text { lactation } \\
{[1]=\text { yes }} \\
{[2]=\text { no }}\end{array}$} & \multicolumn{2}{|c|}{$\begin{array}{l}\text { Average Milk } \\
\text { production } \\
\text { (kg/day if } \\
\text { applicable) }\end{array}$} \\
\hline & & & & & & & Current & $\begin{array}{c}\text { Peak } \\
\text { milk } \\
\text { yield* }^{*}\end{array}$ \\
\hline 1 & & & & & & & & \\
\hline 2 & & & & & & & & \\
\hline 3 & & & & & & & & \\
\hline 4 & & & & & & & & \\
\hline 5 & & & & & & & & \\
\hline 6 & & & & & & & & \\
\hline 7 & & & & & & & & \\
\hline 8 & & & & & & & & \\
\hline 9 & & & & & & & & \\
\hline 10 & & & & & & & & \\
\hline 11 & & & & & & & & \\
\hline 12 & & & & & & & & \\
\hline 13 & & & & & & & & \\
\hline 14 & & & & & & & & \\
\hline 15 & & & & & & & & \\
\hline 16 & & & & & & & & \\
\hline 17 & & & & & & & & \\
\hline 18 & & & & & & & & \\
\hline 19 & & & & & & & & \\
\hline 20 & & & & & & & & \\
\hline
\end{tabular}

b. * for the cows in the first lactation that have no data on peak milk yield leave the column blank. 


\section{Details of The Dairy Herd and Milk Production (II)}

c. Please list the details for your current dairy herd and disaggregate by cow (incl. heifers, calves, bulls - calving and lactation data for cows only if applicable):

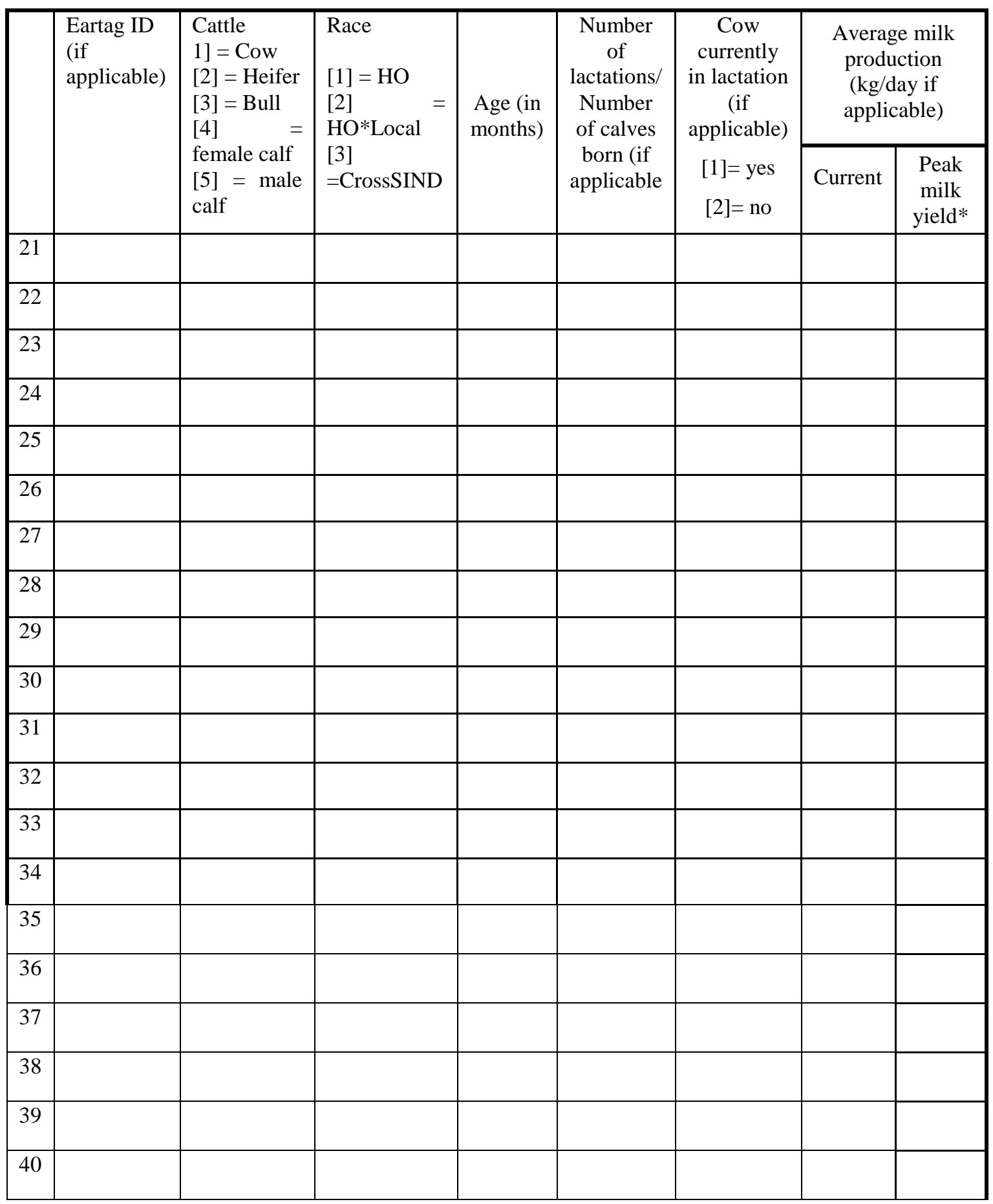

d. $\quad *$ for the cows in the first lactation that have no data on peak milk yield leave the column blank. 


\section{DAIRY HERD DEVELOPMENT OVER TIME}

Please indicate the development of your cattle herd between October 2010 and May 2011.

\begin{tabular}{|c|c|c|c|c|c|c|c|c|c|c|c|c|c|}
\hline \multirow{2}{*}{$\begin{array}{l}\text { Cow } \\
\text { type }\end{array}$} & \multirow{2}{*}{$\begin{array}{l}\text { Stock } \\
\text { Oct } \\
2010\end{array}$} & \multicolumn{3}{|c|}{$\begin{array}{c}\text { Sold/ Slaughtered/ } \\
\text { dead }\end{array}$} & \multicolumn{3}{|c|}{$\begin{array}{l}\text { Purchased } \\
\text { externally }\end{array}$} & \multicolumn{3}{|c|}{$\begin{array}{l}\text { Born \& Raised } \\
\text { internally }\end{array}$} & \multirow{2}{*}{$\begin{array}{l}\text { Grad } \\
\text {. out }\end{array}$} & \multirow{2}{*}{$\begin{array}{l}\text { Grad } \\
\text {. in }\end{array}$} & \multirow{2}{*}{$\begin{array}{c}\text { Stoc } \\
\mathrm{k} \text { as } \\
\text { of } \\
\text { today }\end{array}$} \\
\hline & & $\begin{array}{l}\text { Qt } \\
\mathrm{y}\end{array}$ & $\begin{array}{l}\text { Unit } \\
\text { pric } \\
\mathrm{e} \\
\end{array}$ & $\begin{array}{l}\text { Total } \\
\text { valu } \\
\text { e }\end{array}$ & $\begin{array}{l}\text { Qt } \\
\mathrm{y}\end{array}$ & $\begin{array}{l}\text { Unit } \\
\text { pric } \\
\mathrm{e}\end{array}$ & $\begin{array}{l}\text { Total } \\
\text { valu } \\
\text { e }\end{array}$ & $\begin{array}{l}\text { Qt } \\
\mathrm{y}\end{array}$ & $\begin{array}{l}\text { Unit } \\
\text { pric } \\
\mathrm{e}\end{array}$ & \begin{tabular}{|l|l} 
Total \\
valu \\
e \\
\end{tabular} & & & \\
\hline \multicolumn{14}{|l|}{ Bull } \\
\hline \multicolumn{14}{|l|}{$\begin{array}{l}\text { Male } \\
\text { calf }\end{array}$} \\
\hline \multicolumn{14}{|l|}{$\begin{array}{l}\text { Femal } \\
\text { e calf }\end{array}$} \\
\hline \multicolumn{14}{|l|}{ Heifer } \\
\hline $\begin{array}{l}\text { Cow } \\
\text { (dry \& } \\
\text { milk- } \\
\text { ing) }\end{array}$ & & & & & & & & & & & & & \\
\hline
\end{tabular}




\section{DAILY FODDER USAGE IN DAIRY PRODUCTION DURING THE DRY SEASON - COMPOSITION OF DAILY COW FODDER RATIONS}

Please indicate which type of fodder you feed in what quantity to your dairy cows per day disaggregated by variety (if applicable) and lactation period (write 0 if a specific type of fodder is not used at all by this household; leave blank if farmer doesn't know):

\begin{tabular}{|c|c|c|c|c|c|c|c|c|c|}
\hline \multirow{4}{*}{ Feed \& F } & \multicolumn{9}{|c|}{ Quantity } \\
\hline & \multicolumn{3}{|c|}{ Holstein-Friesian (HO) } & \multicolumn{3}{|c|}{$\begin{array}{l}\text { Crossbred } \\
\left(\mathrm{HO}^{*} \text { Local) }\right.\end{array}$} & \multicolumn{3}{|c|}{ SIND-Cross } \\
\hline & $\begin{array}{l}\text { Avg. } \\
\text { In-milk }\end{array}$ & $\begin{array}{l}\text { Peak } \\
\text { milk }\end{array}$ & Dry & $\begin{array}{l}\text { Avg. } \\
\text { In- } \\
\text { milk }\end{array}$ & $\begin{array}{l}\text { Peak } \\
\text { milk }\end{array}$ & Dry & $\begin{array}{l}\text { Avg. } \\
\text { In- } \\
\text { milk }\end{array}$ & $\begin{array}{l}\text { Peak } \\
\text { milk }\end{array}$ & Dry \\
\hline & kg/day & $\mathrm{kg} /$ day & $\mathrm{kg} /$ day & $\mathrm{kg} / \mathrm{day}$ & $\mathrm{kg} /$ day & $\mathrm{kg} / \mathrm{day}$ & $\mathrm{kg} /$ day & kg/day & kg/day \\
\hline Green Fo & & & & & & & & & \\
\hline Elephant & & & & & & & & & \\
\hline Other gra & & & & & & & & & \\
\hline Dry Fodc & & & & & & & & & \\
\hline Rice Stra & & & & & & & & & \\
\hline Purchase & & & & & & & & & \\
\hline Concentri & & & & & & & & & \\
\hline Beer resic & & & & & & & & & \\
\hline Cassava $\mathrm{r}$ & & & & & & & & & \\
\hline Rice bran & & & & & & & & & \\
\hline $\begin{array}{l}\text { Minerals } \\
\text { calcium) }\end{array}$ & & & & & & & & & \\
\hline Others: & & & & & & & & & \\
\hline
\end{tabular}




\section{DAILY FODDER USAGE IN DAIRY PRODUCTION DURING THE RAINY SEASON - COMPOSITION OF DAILY COW FODDER RATIONS}

Please indicate which type of fodder you feed in what quantity to your dairy cows per day disaggregated by variety (if applicable) and lactation period (write 0 if a specific type of fodder is not used at all by this household; leave blank if farmer doesn't know):

\begin{tabular}{|c|c|c|c|c|c|c|c|c|c|}
\hline \multirow{4}{*}{ Feed \& F } & \multicolumn{9}{|c|}{ Fodder quantity for an average cow } \\
\hline & \multicolumn{3}{|c|}{ Holstein-Friesian (HO) } & \multicolumn{3}{|c|}{$\begin{array}{l}\text { Crossbred } \\
\text { (HO*Local) }\end{array}$} & \multicolumn{3}{|c|}{ SIND-Cross } \\
\hline & $\begin{array}{l}\text { Avg. } \\
\text { In-milk }\end{array}$ & $\begin{array}{l}\text { Peak } \\
\text { milk }\end{array}$ & Dry & $\begin{array}{l}\text { Avg. } \\
\text { In- } \\
\text { milk }\end{array}$ & $\begin{array}{l}\text { Peak } \\
\text { milk }\end{array}$ & Dry & $\begin{array}{l}\text { Avg. } \\
\text { In- } \\
\text { milk }\end{array}$ & $\begin{array}{l}\text { Peak } \\
\text { milk }\end{array}$ & Dry \\
\hline & kg/day & $\mathrm{kg} /$ day & $\mathrm{kg} /$ day & $\mathrm{kg} /$ day & $\mathrm{kg} /$ day & $\mathrm{kg} / \mathrm{day}$ & $\mathrm{kg} /$ day & kg/day & kg/day \\
\hline Green Fo & & & & & & & & & \\
\hline Elephant & & & & & & & & & \\
\hline Other gra & & & & & & & & & \\
\hline Dry Fodc & & & & & & & & & \\
\hline Rice Stra & & & & & & & & & \\
\hline Purchase & & & & & & & & & \\
\hline Concentri & & & & & & & & & \\
\hline Beer resic & & & & & & & & & \\
\hline Cassava $\mathrm{r}$ & & & & & & & & & \\
\hline Rice bran & & & & & & & & & \\
\hline $\begin{array}{l}\text { Minerals } \\
\text { calcium) }\end{array}$ & & & & & & & & & \\
\hline Others: & & & & & & & & & \\
\hline
\end{tabular}




\section{Purchased Feed IN DAIRY PRODUCTION}

Please indicate which type of fodder you purchased to use in dairy production (cows, heifers, calves, bulls) over the last 12 months (Most important: Total value):

\begin{tabular}{|l|l|l|l|}
\hline$\#$ & Type of feed/fodder & \multicolumn{2}{|c|}{ Total purchases } \\
\cline { 3 - 4 } & & Total quantity & Total Value \\
\hline 1 & Rice Straw & & \\
\hline 2 & Concentrate Type Con co & & \\
\hline 3 & Concentrate Type Thai Duong & & \\
\hline 4 & Concentrate Type & & \\
\hline 5 & Beer residue & & \\
\hline 6 & Cassava residue & & \\
\hline 7 & Rice bran & & \\
\hline 8 & Minerals & & \\
\hline 9 & Milk substitute/replacer for feeding calves & & \\
\hline 10 & Others (please indicate): & & \\
\hline
\end{tabular}

\section{Veterinary service}

Provide information on the following activities for the last 12 months

\begin{tabular}{|l|l|l|l|l|l|}
\hline$\#$ & Items & Quantity & Source* & Unit price & $\begin{array}{l}\text { Total value } \\
\text { (VND`000) }\end{array}$ \\
\hline 1 & Artificial insemination & & & & \\
\hline 2 & Vaccination (FMD) & & & & \\
\hline 3 & Vaccine - Tu huyet trung & & & & \\
\hline 4 & Disease treatment & & & & \\
\hline 5 & Tonic medicine (biodin) & & & & \\
\hline 6 & Other (specify) & & & & \\
\hline
\end{tabular}

* 1: government agency ${ }^{13}$; 2 : private sector; 3: self service; 4: other.

If quantity and/or price for veterinary services are uncertain, estimate total value of services (including medicine) bought over the last 12 months VND

${ }^{13}$ If commune veterinary surgeons work for government project/programs put 1; if deliver service put 2. 
Do you use a teat dip cup for cleaning/care the udder before/after milking?

$\square$ Yes

$$
\square \text { No }
$$

\section{OTHER EXPENDITURE:}

How much money have you spent over the last 12 month in dairy production on

\begin{tabular}{|l|l|l|}
\hline$\#$ & \multicolumn{1}{|c|}{ Items } & $\begin{array}{l}\text { Annual cost } \\
\text { (VND’000) }\end{array}$ \\
\hline 1 & Repair of cattle shed & \\
\hline 2 & $\begin{array}{l}\text { Repair of dairy equipment (milking machine, containers, mosquito net, } \\
\text { etc.) }\end{array}$ & \\
\hline 3 & Costs for electricity in the cattle shed (lighting, ventilation) & \\
\hline 4 & Gasoline for milk transportation & \\
\hline 5 & Other (specify) & \\
\hline
\end{tabular}

\section{BY-PRODUCTS OF DAIRY PRODUCTION}
Do you sell manure to other farmers?
$\square$ Yes
$\square$ No

If yes how much did you sell during the last 12 months?

Quantity sold (bags)

Total value

Did you feed some of your milk to calves during the last 12 months? $\square$ Yes

$\square$ No

If yes, estimate how much milk did you feed (and could not sell) during the last 12 months?

Quantity feed (kg)

Total value (at market price)

Did you (instead of cow milk) feed milk substitute/replacer to your calves? $\quad \square$ Yes $\quad \square$ No

\section{MILK SALE}

Distance to the Vinamilk milk collection center: $\mathrm{km}$

Conveyance used for transporting milk: $\quad \square$ On foot $\quad \square$ Bicycle $\quad \square$ Motorcycle

$\square$ Three-Four-wheel motorized vehicle.

Number of trips to the MCC per day ${ }^{14:}$

Whose containers are being used for transporting milk? $\quad \square$ Own $\quad \square$ Vinamilk’s $\quad \square$ Both

Besides Vinamilk, are there any other companies than Vinamilk in a for you manageable distance that would on a regular basis buy the milk you produce (e.g. Dutch Lady)

$\square$ Yes

$\square$ No

\footnotetext{
${ }^{14}$ If the household does mutual help in milk transportation, number of trips are the actual average number of trips during the day
} 


\section{HUMAN LABOUR EMPLOYMENT IN DAIRYING}

Please report the labor you spend per day on the following operations in minutes

\begin{tabular}{|c|c|c|c|c|c|c|}
\hline \multirow{3}{*}{ Operations } & \multicolumn{6}{|c|}{$\begin{array}{l}\text { Human Labor used per Household (indicate } \\
\text { minutes per day normally used for different } \\
\text { activities) }\end{array}$} \\
\hline & \multicolumn{3}{|c|}{ Family labor } & \multicolumn{3}{|c|}{ Hired labor } \\
\hline & M & $\mathrm{F}$ & $\mathrm{C}$ & $\mathrm{M}$ & $\mathrm{F}$ & $\mathrm{C}$ \\
\hline Bringing fodder from field, chaff cutting of fodder & & & & & & \\
\hline Feeding the cows & & & & & & \\
\hline $\begin{array}{l}\text { Cattle shed cleaning, Animal cleaning and } \\
\text { veterinary treatments (carried out by the farmer } \\
\text { himself) and other operations }\end{array}$ & & & & & & \\
\hline Milking cows & & & & & & \\
\hline Transporting milk to the milk collection center & & & & & & \\
\hline Any other (Specify) & & & & & & \\
\hline $\begin{array}{l}\text { Wage rate (VND/day) incl. estimated value of in- } \\
\text { kind payment }\end{array}$ & & & & & & \\
\hline
\end{tabular}

$$
M=\text { Male } \quad F=\text { Female } \quad C=\text { Child (less than } 15 \text { years) }
$$

How often do you feed your dairy cows with concentrate?

$$
\square 2 \square 3 \quad \square 4 \text { times a day. }
$$

How often do you feed your dairy cows with grass? $\quad \square 2 \quad \square 3 \quad \square 4$ times $\quad \square$

Whole day.

\section{MILK QUALITY}

In the past month, have you experienced problems in achieving good results in one of the following milk quality parameters?

\begin{tabular}{|l|l|l|l|}
\hline$\#$ & Milk quality parameters & Yes & No \\
\hline 1 & Total solid & & \\
\hline 2 & Milk fat & & \\
\hline 3 & Bacterial contamination & & \\
\hline 4 & Somatic cell & & \\
\hline
\end{tabular}




\section{STATEMENTS ON DAIRY FARMING}

Please score the following statements:

\begin{tabular}{|c|c|c|c|c|c|c|}
\hline \multirow[t]{2}{*}{$\begin{array}{l}\text { S. } \\
\text { No. }\end{array}$} & \multirow[t]{2}{*}{ Statement } & \multicolumn{5}{|c|}{$\begin{array}{l}\text { e. Response } \\
\text { (please tick) }\end{array}$} \\
\hline & & 1 & 2 & 3 & 4 & 5 \\
\hline 1 & Access to artificial insemination services is good & & & & & \\
\hline 2 & $\begin{array}{l}\text { It is difficult to get the cows in my herd pregnant with artificial } \\
\text { insemination }\end{array}$ & & & & & \\
\hline 3 & $\begin{array}{l}\text { I have enough pasture/grassland to sufficiently feed my cows all } \\
\text { year round }\end{array}$ & & & & & \\
\hline 4 & The costs of purchased fodder (i.e. concentrate) is too high & & & & & \\
\hline 5 & I have the necessary know-how on balanced feeding & & & & & \\
\hline 6 & $\begin{array}{l}\text { It is difficult to get access to veterinary services (vaccinations, } \\
\text { disease treatment, etc.) }\end{array}$ & & & & & \\
\hline 7 & $\begin{array}{l}\text { Revenues from milk production are sufficient to allow for further } \\
\text { investment in dairy production }\end{array}$ & & & & & \\
\hline 8 & Purchased fresh milk price is too low & & & & & \\
\hline 9 & My cows are often sick (e.g. mastitis) & & & & & \\
\hline
\end{tabular}

1 = I strongly disagree; 2 = I disagree, 3 = I agree; 4 = I strongly agree; 5 = I don’t know

Enumertator, please present farmer pictures to interviewee

Please look at the pictures and identify those farmers (or HH-members of farmers) who are familiar to you. Out of those familiar to you, please point out the 3 most important persons in terms of information sharing about dairy production (production technology, prices, etc.) Enumerator, please note down UID below

1st most important contact:

$2^{\text {nd }}$ most important contact: .

$3^{\text {rd }}$ morst important contact:

Pls score the following statements:

\begin{tabular}{|c|c|c|c|c|c|c|c|c|c|c|c|}
\hline \multirow{2}{*}{$\begin{array}{l}\text { S. } \\
\text { No. }\end{array}$} & \multirow{2}{*}{ Statement } & f. & \multicolumn{4}{|c|}{ Low } & \multicolumn{3}{|c|}{ g. } & \multicolumn{2}{|c|}{ High } \\
\hline & & 1 & 2 & 3 & 4 & 5 & 6 & 7 & 8 & 9 & 10 \\
\hline 1 & Before the project my trust to Vinamilk was & & & & & & & & & & \\
\hline 2 & Now my trust to Vinamilk is & & & & & & & & & & \\
\hline
\end{tabular}

\section{In what group are you?}
$\square$ Control
$\square$ Voucher
$\square$ I don’t know 


\section{EVALUATION OF THE TREATMENTS: Control (if applicable)}

\section{Pls score the following statements}

\begin{tabular}{|l|l|l|l|l|l|}
\hline \multirow{2}{*}{$\begin{array}{l}\text { S. } \\
\text { No. }\end{array}$} & Statement & \multicolumn{3}{|c|}{ h. } \\
Response \\
\cline { 2 - 5 } 1 & $\begin{array}{l}\text { Even though I am not in the voucher group it seems that Vinamilk } \\
\text { now plays fair with all farmers and thus I also benefit from the } \\
\text { voucher. }\end{array}$ & $\mathbf{1}$ & $\mathbf{3}$ & $\mathbf{4}$ & $\mathbf{5}$ \\
\hline 2 & $\begin{array}{l}\text { The relationship to Vinamilk became more trustful since the project } \\
\text { started. }\end{array}$ & & & & \\
\hline 3 & $\begin{array}{l}\text { I apply some of the techniques that were taught to farmers in the } \\
\text { extension group. Thus I benefited from it as well. }\end{array}$ & & & & \\
\hline
\end{tabular}

1 = I strongly disagree; 2 = I disagree, 3 = I agree; 4 = I strongly agree; 5 = I don’t know

\section{EVALUATION OF THE TREATMENTS: VOUCHER (if applicable)}

Do you see the change in the Vinamilk's milk quality testing results since the project starts?

$$
\square \text { Yes } \quad \square \text { No }
$$

If yes, the change is in good or bad direction? $\quad \square$ Worse $\square$ better

Please score the following statements:

\begin{tabular}{|c|c|c|c|c|c|c|}
\hline \multirow[t]{2}{*}{$\begin{array}{l}\text { S. } \\
\text { No. }\end{array}$} & \multirow[t]{2}{*}{ Statement } & \multicolumn{5}{|c|}{$\begin{array}{l}\text { i. Response } \\
\text { (please tick) }\end{array}$} \\
\hline & & 1 & 2 & 3 & 4 & 5 \\
\hline 1 & The voucher for free verification of milk testing results is useful & & & & & \\
\hline 2 & $\begin{array}{l}\text { The cross checking of Vinamilk's testing results makes the company } \\
\text { play fairer }\end{array}$ & & & & & \\
\hline 3 & $\begin{array}{l}\text { From my point of view the independent lab of Quatest3 is } \\
\text { trustworthy }\end{array}$ & & & & & \\
\hline 4 & $\begin{array}{l}\text { It would be appreciated if after the project ends quality of milk is } \\
\text { analyzed only by an independent lab }\end{array}$ & & & & & \\
\hline 5 & $\begin{array}{l}\text { For me it does not make a difference if Vinamilk or any other body } \\
\text { carries out the milk quality analysis; }\end{array}$ & & & & & \\
\hline
\end{tabular}

1 = I strongly disagree; 2 = I disagree, 3 = I agree; 4 = I strongly agree; 5 = I don’t know

Do you still have the vouchers and the instruction sheet that was issued to you during the Farmers' Workshop in October 2009 (or that had been distributed afterwards). $\quad$ Yes $\quad \square$ No 
Have you ever executed one or more of these vouchers?

\begin{tabular}{|l|l|l|l|l|l|l|}
\hline S. & Statement & \multicolumn{5}{|l|}{ j. } \\
No. & & Response (please \\
\cline { 3 - 7 } & & $\mathbf{1}$ & $\mathbf{2}$ & $\mathbf{3}$ & $\mathbf{4}$ & $\mathbf{5}$ \\
\hline 1 & In terms of the procedure it is easy to execute a voucher & & & & & \\
\hline 2 & I don't feel comfortable double checking behind Vinamilk's back & & & & & \\
\hline
\end{tabular}

1 = I strongly disagree; 2 = I disagree, 3 = I agree; 4 = I strongly agree; 5 = I don’t know.

If "No" please score the following statements (otherwise skip):

\begin{tabular}{|c|c|c|c|c|c|c|}
\hline \multirow[t]{2}{*}{$\begin{array}{l}\text { S. } \\
\text { No. }\end{array}$} & \multirow[t]{2}{*}{ Statement } & \multicolumn{5}{|c|}{$\begin{array}{l}\text { k. Response } \\
\text { (please tick) }\end{array}$} \\
\hline & & 1 & 2 & 3 & 4 & 5 \\
\hline 1 & In terms of the procedure it is easy to execute a voucher & & & & & \\
\hline 2 & $\begin{array}{l}\text { So far I haven't executed a voucher since the quality reported by } \\
\text { Vinamilk was good }\end{array}$ & & & & & \\
\hline 3 & $\begin{array}{l}\text { So far I haven't executed a voucher because I fear the results from the } \\
\text { independent laboratory could be lower than those reported by Vinamilk } \\
\text { and I would lose money }\end{array}$ & & & & & \\
\hline 4 & I don't feel comfortable double checking behind Vinamilk's back & & & & & \\
\hline 5 & $\begin{array}{l}\text { The voucher is useful because sometimes I want to double check the } \\
\text { quality reported by Vinamilk }\end{array}$ & & & & & \\
\hline
\end{tabular}

1 = I strongly disagree; 2 = I disagree, 3 = I agree; 4 = I strongly agree; 5 = I don’t know.

If none of the above mentioned statements apply to you, is there any other comment/concern you would like to share with us regarding the voucher treatment?

Please score the following statements:

\begin{tabular}{|l|l|l|l|l|l|l|}
\hline \multirow{2}{*}{$\begin{array}{l}\text { S. } \\
\text { No. }\end{array}$} & Statement & \multicolumn{4}{|c|}{ l. Response (please } \\
& & \multicolumn{4}{|c|}{ tick) } \\
\cline { 3 - 6 } 1 & $\begin{array}{l}\text { I apply some of the techniques that were taught to farmers in the } \\
\text { extension group. Thus I benefited from it as well. }\end{array}$ & & $\mathbf{1}$ & $\mathbf{3}$ & $\mathbf{4}$ & $\mathbf{5}$ \\
\hline
\end{tabular}

1 = I strongly disagree; 2 = I disagree, 3 = I agree; 4 = I strongly agree; 5 = I don’t know. 


\section{SOCIAL CAPITAL: TRUST}

Please score the following statements (Please tick):

\begin{tabular}{|c|c|c|c|c|c|}
\hline Statement & 1 & 2 & 3 & 4 & 5 \\
\hline \multicolumn{6}{|c|}{ Purchased concentrate feed is of constantly good quality } \\
\hline \multicolumn{6}{|c|}{$\begin{array}{l}\text { Artificial Insemination services provided are of constantly good } \\
\text { quality }\end{array}$} \\
\hline \multicolumn{6}{|c|}{ My milk collection center is a trustworthy business partner } \\
\hline \multicolumn{6}{|c|}{ Vinamilk is a trustworthy business partner } \\
\hline Fellow farmers are trustworthy & & & & & \\
\hline
\end{tabular}

1 = I strongly disagree; 2 = I disagree, 3 = I agree; 4 = I strongly agree; 5 = I don’t know

\section{TIME PREFERENCES}

Suppose the government sets up a support-program for dairy farmers and decides to pay you a one-time bonus of 2,500,000 VND. They give you two options. In the first option, you get paid the one-time bonus of 2,500,000 VND tomorrow. In the second option, you get paid the one-time bonus 1 month from now, but you will be paid more than 2,500,000 VND. So, you are paid extra for waiting one additional month. In each of the following cases, which option would you prefer? (Go through each line (pair-wise comparison) and check the answer separately)

\begin{tabular}{|c|c|c|c|c|}
\hline & Tomorrow & & In 1 month & Monthly Interest rate equivalent \\
\hline & $2,500,000 \mathrm{VND}$ & & $2,507,000 \mathrm{VND}$ & $0.3 \%$ \\
\hline & $2,500,000 \mathrm{VND}$ & & $2,512,500 \mathrm{VND}$ & $1.0 \%$ \\
\hline & $2,500,000 \mathrm{VND}$ & & $2,525,000 \mathrm{VND}$ & $1.5 \%$ \\
\hline & $2,500,000 \mathrm{VND}$ & & $2,538,000 \mathrm{VND}$ & $2.0 \%$ \\
\hline & $2,500,000 \mathrm{VND}$ & & $2,550,000 \mathrm{VND}$ & $2.5 \%$ \\
\hline & $2,500,000 \mathrm{VND}$ & & $2,563,000 \mathrm{VND}$ & $3.5 \%$ \\
\hline & $2,500,000 \mathrm{VND}$ & & $2,588,000 \mathrm{VND}$ & $5.0 \%$ \\
\hline & $2,500,000 \mathrm{VND}$ & & $2,625,000 \mathrm{VND}$ & $10.0 \%$ \\
\hline & $2,500,000 \mathrm{VND}$ & & $2,750,000 \mathrm{VND}$ & $15.0 \%$ \\
\hline & $2,500,000 \mathrm{VND}$ & & $3,000,000 \mathrm{VND}$ & $20.0 \%$ \\
\hline
\end{tabular}

If the respondent answered "2,500,000 VND tomorrow" in all of the above cases, ask the following question: How much would the government have to pay you in order for you to wait 1 month? 
AGRICUTLURAL ASSETS PURCHASED OVER THE LAST 12 MONTHS

\begin{tabular}{|c|c|c|c|}
\hline$\#$ & Item & Quantity & $\begin{array}{l}\text { Bought value } \\
\text { (VND’000) }\end{array}$ \\
\hline 1 & Pesticide Sprayer & & \\
\hline 2 & Grass cutting device (manual) & & \\
\hline 3 & Hand-tractor & & \\
\hline 4 & Tractor & & \\
\hline 5 & Plough (for tractor) & & \\
\hline 6 & Tiller (for tractor) & & \\
\hline 7 & Trailer/Cart & & \\
\hline 8 & Rice milling machine & & \\
\hline 9 & Feed grinding machine & & \\
\hline 10 & Boat & & \\
\hline 11 & Pump & & \\
\hline 12 & Power generator & & \\
\hline 13 & Milking machine & & \\
\hline 14 & Motorbike & & \\
\hline 15 & Bicycle & & \\
\hline 16 & Animal shed (non-dairy) (m2) & & \\
\hline 17 & Warehouse (m2) & & \\
\hline 18 & Area for drying crops (m2) & & \\
\hline 19 & Others; & & \\
\hline
\end{tabular}


MODULE: CONSUMPTION AND EXPENDITURES

Enumerator, whenever possible, these questions should be asked in the presence of both husband and wife. Enumerator: In questions 1 to 17 , the quantity consumed and the corresponding value should include both consumption from own production and consumption from purchases. If the respondent does not know the value of the own consumption, ask the unit price on the market for the product, and multiply it by the quantity consumed. (Table continues on the next page)

\begin{tabular}{|c|c|c|c|}
\hline $\begin{array}{l}\text { Expenditures on food } \\
\text { (LAST } 7 \text { DAYS) }\end{array}$ & $\begin{array}{l}\text { Total value } \\
\text { (VND’000) }\end{array}$ & $\begin{array}{l}\text { Consumption of durable goods and other expenditures } \\
\text { (LAST } 12 \text { MONTHS) }\end{array}$ & $\begin{array}{l}\text { Total value } \\
\text { (VND’000) }\end{array}$ \\
\hline 1. Rice & & 23. Clothing (all sort of clothing for all) & \\
\hline 3. Potato/sweed potato & & 24. Shoes (all sorts of shoes for all) (number of pairs) & \\
\hline 3. Pulses & & 25. Quilt/mattress/pillow/bed sheet etc. & \\
\hline 4. Fish & & 26. Furniture (Chair/table/cot etc) & \\
\hline 5. Meat & & 27. Radio/television/bicycle/cart etc & \\
\hline 6. Egg & & 28. Ornaments & \\
\hline 7. Cooking Oil & & 29. Pot/pan/plate/glass/spoon etc. & \\
\hline 8. Milk & & 30. House repairing/development/making & \\
\hline 9. Sugar, Molasse & & 31. Hurricane/lantern/petromax/kupi/torch/charger etc. & \\
\hline 10. Vegetables, Salt, Spices & & 32. Toll/tax/litigation etc. & \\
\hline 11. Fruits & & 33. Social/religious/marriage/birth/death/dowry etc. & \\
\hline 12. Tobacco & & 34. Salary of servant/maid servant (excl food and cloth) & \\
\hline 13. Coffee & & 35. Education & \\
\hline 14. Wine/beverage (not including 33) & & 36. Shave/blade/razor/cobbler/laundry etc. & \\
\hline 15. Other, specify & & 37. Others & \\
\hline $\begin{array}{c}\text { Expenditures on daily necessaries and others } \\
\text { (LAST } 1 \text { MONTH) }\end{array}$ & $\begin{array}{l}\text { Total value } \\
\text { (VND’000) }\end{array}$ & $\begin{array}{l}\text { Energy related expenditures } \\
\text { (LAST } 12 \text { MONTHS) }\end{array}$ & $\begin{array}{l}\text { Total value } \\
\text { (VND’000) }\end{array}$ \\
\hline 16. Soap/soda/cosmetics etc. (last 1 month) & & 38. Diesel, Kerosene, gasoline & \\
\hline 17. Tour/travel/journey/cinema etc. (last 1 month) & & 39. Gas cylinder - recharge & \\
\hline 18. Health (medicine/doctor, etc & & 40. Maintenance of solar PV & \\
\hline 19. Electricity & & 41. Maintenance of own Electricity generator set & \\
\hline 20. Water for house & & 42. Car battery & \\
\hline 21. Telephone & & 43. Others & \\
\hline 22. Other (specify) & & & \\
\hline
\end{tabular}

